\title{
Syngas for biorefineries from thermochemical gasification of lignocellulosic fuels and residues -5 years' experience with an advanced dual fluidized bed gasifier design
}

\author{
Johannes Christian Schmid ${ }^{1,2} \cdot$ Florian Benedikt $^{1} \cdot$ Josef Fuchs $^{1} \cdot$ Anna Magdalena Mauerhofer $^{1}$ (D) $\cdot$ Stefan Müller ${ }^{1,3}$. \\ Hermann Hofbauer ${ }^{1}$
}

Received: 16 April 2019 / Revised: 24 July 2019 / Accepted: 24 July 2019 / Published online: 16 August 2019

(C) The Author(s) 2019

\begin{abstract}
In many processes proposed for biorefineries, recycling procedures, and industrial or agricultural production processes, residue is generated which could be further transformed by thermochemical conversion via gasification. The technology of dual fluidized bed steam gasification is capable of producing a valuable product gas out of such residue. The generated nitrogen-free product gas can be used for heat and power production and is suitable for separating gases (e.g. hydrogen). However, if the product gas is cleaned, its use as syngas is more beneficial for manufacturing renewable chemical substances, like synthetic natural gas, methanol, Fischer-Tropsch liquids, or mixed alcohols. This paper presents the results of experimental research from gasification test runs of different biogenic fuels, carried out with an advanced $100 \mathrm{~kW}$ pilot plant over the last 5 years at TU Wien. The focus is to provide an overview of measured results validated by mass and energy balances and to present key calculated performance indicating key figures of the test runs. In this way, the influence of various operational parameters and the composition of the product gas are evaluated. The presented results form the basis for the proper design of suitable gas-cleaning equipment. Subsequently, the clean syngas is available for several synthesis applications in future biorefineries.
\end{abstract}

Keywords Biomass $\cdot$ Steam gasification $\cdot$ Reactor design $\cdot$ Product gas $\cdot$ Synthesis gas $\cdot$ Biofuel

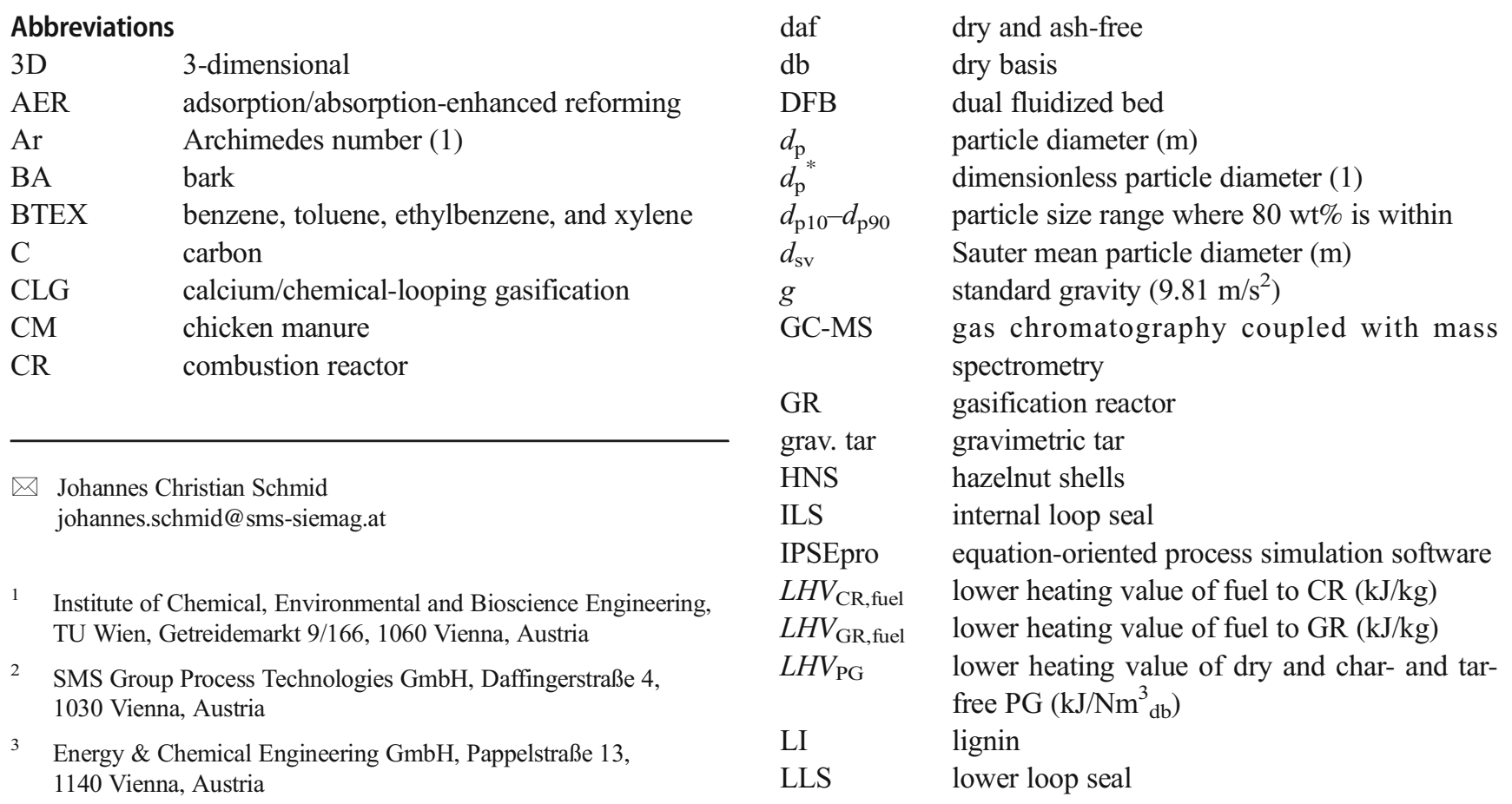




\begin{tabular}{|c|c|}
\hline$\dot{m}_{\mathrm{CR}, \text { fuel }}$ & mass flow of fuel to $\mathrm{CR}(\mathrm{kg} / \mathrm{s})$ \\
\hline$\dot{m}_{\mathrm{GR}, \text { fuel }}$ & mass flow of fuel to GR $(\mathrm{kg} / \mathrm{s})$ \\
\hline$\dot{m}_{\mathrm{C}, \mathrm{GR}, \text { fuel }}$ & mass flow of carbon in fuel to GR $(\mathrm{kg} / \mathrm{s})$ \\
\hline$\dot{m}_{\mathrm{GR}, \text { fuel,daf }}$ & $\begin{array}{l}\text { mass flow of dry and ash-free fuel to GR }\left(\mathrm{kg}_{\mathrm{dat}}\right) \\
\text { s) }\end{array}$ \\
\hline$\dot{m}_{\mathrm{H} 2 \mathrm{O}, \mathrm{GR}, \text { fuel }}$ & mass flow of water in fuel to GR $(\mathrm{kg} / \mathrm{s})$ \\
\hline$\dot{m}_{\mathrm{H} 2 \mathrm{O}, \mathrm{PG}}$ & mass flow of water in $\mathrm{PG}(\mathrm{kg} / \mathrm{s})$ \\
\hline$\dot{m}_{\text {steam,GR }}$ & mass flow of steam to GR $(\mathrm{kg} / \mathrm{s})$ \\
\hline$p_{\mathrm{CO} 2}$ & partial pressure of $\mathrm{CO}_{2}$ (bar) \\
\hline PG & product gas \\
\hline PGY & product gas yield $\left(\mathrm{Nm}_{\mathrm{db}}^{3} / \mathrm{kg}_{\text {fuel, daf }}\right)$ \\
\hline PLC & programmable logic controller \\
\hline$\dot{Q}_{\text {loss }}$ & radiative heat losses $(\mathrm{kW})$ \\
\hline $\operatorname{Re}$ & Reynolds number (1) \\
\hline RH & rice husk \\
\hline RME & rapeseed methyl ester, bio-diesel \\
\hline SCB & sugarcane bagasse \\
\hline SEG & sorption-enhanced gasification \\
\hline SER & sorption-enhanced reforming \\
\hline SNG & synthetic natural gas \\
\hline ST & straw \\
\hline SW & softwood \\
\hline TU Wien & Vienna University of Technology \\
\hline$U$ & fluidization velocity $(\mathrm{m} / \mathrm{s})$ \\
\hline$U^{*}$ & dimensionless fluidization velocity (1) \\
\hline ULS & upper loop seal \\
\hline vol\% & percent by volume \\
\hline vol ppm & parts per million by volume \\
\hline$\dot{V}_{\mathrm{PG}}$ & dry volumetric product gas flow $\left(\mathrm{Nm}_{\mathrm{db}}^{3} / \mathrm{s}\right)$ \\
\hline $\mathrm{wt} \%$ & percent by weight, percent by mass \\
\hline$X_{\mathrm{H} 2 \mathrm{O}}$ & steam-related water conversion $\left(\mathrm{kg}_{\mathrm{H} 2 \mathrm{O}} / \mathrm{kg}_{\mathrm{H} 2 \mathrm{O}}\right)$ \\
\hline$\Delta H_{R}$ & standard enthalpy of reaction $(\mathrm{kJ} / \mathrm{mol})$ \\
\hline$\eta_{\mathrm{CG}}$ & cold gas efficiency $(\%)$ \\
\hline$\eta_{\mathrm{CG}, \mathrm{o}}$ & overall cold gas efficiency $(\%)$ \\
\hline$\nu$ & kinematic viscosity $\left(\mathrm{m}^{2} / \mathrm{s}\right)$ \\
\hline$\rho^{*}$ & relative density, dimensionless density ratio (1) \\
\hline$\rho_{\mathrm{g}}$ & gas density $\left(\mathrm{kg} / \mathrm{m}^{3}\right)$ \\
\hline$\rho_{\mathrm{p}}$ & particle density $\left(\mathrm{kg} / \mathrm{m}^{3}\right)$ \\
\hline$\varphi_{\mathrm{SC}}$ & steam-to-carbon ratio $\left(\mathrm{kg}_{\mathrm{H} 2 \mathrm{O}} / \mathrm{kg}_{\mathrm{C}}\right)$ \\
\hline$\varphi_{\mathrm{SF}}$ & steam-to-fuel ratio $\left(\mathrm{kg}_{\mathrm{H} 2 \mathrm{O}} / \mathrm{kg}_{\text {fuel,daf }}\right)$ \\
\hline
\end{tabular}

\section{Introduction}

Gasification processes to convert solid fuels like coal and peat into a burnable gas mixture have been in use since the 1810 s. The main purpose was initially the utilization of the produced gas as a light source and for industrial processes. In the 1920s, inventor F. Winkler introduced the thermochemical conversion of solid fuels by using a fluidized bed gasifier [1]. Several industrial fluidized bed plants were installed and operated mainly for coal gasification. However, a broad breakthrough at the market could not be reached. As extensive networks developed to supply electricity, the demand for mineral oil and natural gas grew worldwide. A new boost for gasification technologies came with the increased interest in biomass utilization at the end of the last century. The intention is to replace fossil fuel-based products at the market with renewable alternatives. Many developments of different gasification technologies were for small, medium, and large scales, and some developments reached market maturity. At the same time, it remained unclear which gasification technologies were most suitable in terms of fuel flexibility and achieving the actual goals of current energy policy such as that of the Paris Climate Targets.

One of the applied biomass gasification technologies is the dual fluidized bed (DFB) steam gasification process [2]. The basic idea of this process is to generate a nitrogen-free product gas from a solid biogenic fuel without using oxygen. Therefore, the technology avoids an energy- and costintensive air separation unit. In the DFB gasification process, the endothermic gasification reactions are locally separated from the exothermic combustion reactions by using two fluidized bed reactors. Levenspiel [3] and Karl and Pröll [4] give an overview of different basic reactor design options. Typically, the bed material of the fluidized bed system circulates from the combustion reactor (CR) to the gasification reactor (GR) and vice versa. A flue gas stream leaves the $\mathrm{CR}$, and the valuable product gas stream leaves the GR. The gases of the reactors remain separated, because the circulation of the hot bed material is realized through steam fluidized loop seals, L-valves, or chutes. The CR operates at a higher temperature than that of the GR. Therefore, the circulating bed material serves as heat carrier and delivers the necessary heat for drying, devolatilization, and the gasification reactions of the fuel in the GR.

The basic principle of a classic DFB gasifier is shown in Figure1. Solid fuel is fed into the GR. Drying, pyrolysis/ devolatilization of the fuel particles, and the gasification of char particles take place in parallel in the GR. Steam is used as a fluidization as well as a gasification agent. The fluidized bed of the GR typically operates as a bubbling fluidized bed at temperatures between 750 and $850^{\circ} \mathrm{C}$. Bed material together with remaining char from the GR is transported to the CR. The $\mathrm{CR}$ is fluidized with air and operates at about 900 to $970{ }^{\circ} \mathrm{C}$. Char from the GR is combusted in the CR, which leads to an increase of the bed material temperature. If required, additional fuel can be applied in the CR to obtain a certain temperature in the GR. At lower temperatures in the GR, no additional fuel is necessary, because a higher amount of remaining char is transported to the CR [5]. Typically, the fixed carbon content of the fuel represents the remaining char available for the combustion for heat generation in the $\mathrm{CR}$. The more heat that is available for the GR, the more fuel/char will be converted, and vice versa. Thus, in principle, the temperature in the DFB gasifier is a self-controlling parameter, depending on the fixed 
product gas

$\mathrm{H}_{2}, \mathrm{CO}, \mathrm{CO}_{2}, \mathrm{CH}_{4}, \mathrm{C}_{2} \mathrm{H}_{4}$
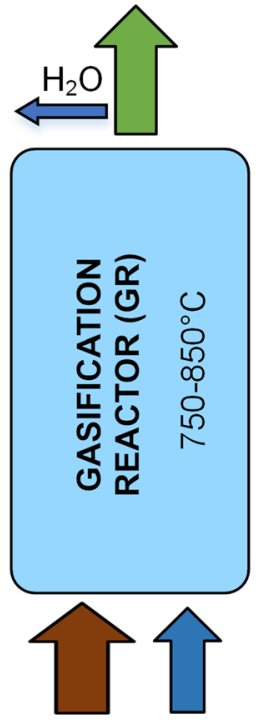

fuel steam flue gas

$\mathrm{N}_{2}, \mathrm{CO}_{2}, \mathrm{H}_{2} \mathrm{O}, \mathrm{O}_{2}$
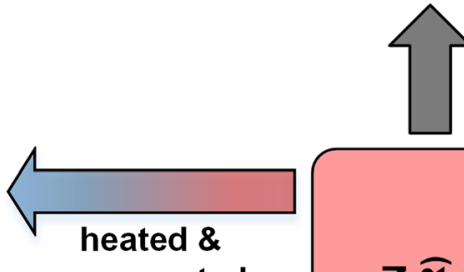
regenerated bed material

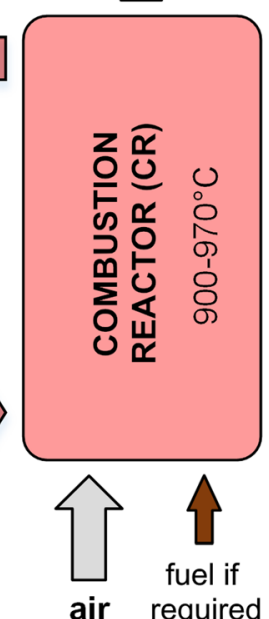

air required

Fig. 1 Basic principle of the classic dual fluidized bed (DFB) gasification

carbon content of the specific fuel type. The type of bed material plays an important role in DFB gasification. As already explained, the bed material is used as a heat carrier. Furthermore, bed material can act as catalyst (e.g., olivine, limestone) to enhance the desired gasification reactions and reduce the undesired tar content. Finally, different bed materials can be used to capture gaseous components (e.g., $\mathrm{CO}_{2}$ from the GR or $\mathrm{O}_{2}$ from the $\mathrm{CR}$ ) and transport them to the other reactor where they are released again.

The DFB steam gasification process using a former classic test plant with $100 \mathrm{~kW}$ fuel power according to Figure 1 was intensively investigated from 1998 to 2013 for lignocellulosic biomass at TU Wien [6-9]. The test unit consisted of a bubbling fluidized bed for the GR and a fast fluidized bed for the CR. At that time, olivine was the preferred bed material. A freeboard was situated above the bubbling fluidized bed of the GR, where practically no bed material particles were present to efficiently support tar reduction or reforming reactions. Based on the extensive results and experience gathered from the classic test plant at TU Wien, several industrial plants were built and operated. The most famous of these industrial plants are those in Güssing ( $8 \mathrm{MW}$ ), Oberwart (8.6 MW), and Senden (15 MW), which were built to produce heat and power. Another plant with a fuel capacity of $33 \mathrm{MW}$ was built in Gothenburg, Sweden, in order to produce 20 MW synthetic natural gas $(\mathrm{SNG})$.

Several years ago, it was concluded that heat and power production from high-quality biomass like wood chips via gasification cannot be executed economically. Therefore, cheaper fuels should be used and products that are more valuable should be generated instead of heat and power [10-12];

such valuable chemical products include hydrogen-methane gas mixtures, hydrogen, synthetic natural gas (SNG), FischerTropsch liquids, methanol, and mixed alcohols, and they can be produced via gas upgrading or reactions. In addition, the direct utilization of the product gas as fuel gas is promising, directly substituting fossil fuels for high-temperature processes in industry. Possible alternative and cheaper fuels are biogenic residues or waste from agriculture, industry, and municipalities like sewage sludge. These are inexpensive materials or have negative prices, but the gasification and gas cleaning are very complex and challenging.

To cope with this challenge, the configuration of the overall gasification process changed essentially via design considerations for the DFB reactor system. Early on, it remained unclear which results could be obtained with an advanced reactor design. Therefore, a new pilot plant was built to evaluate the applied changes in 2013 at TU Wien. Figure 2 shows the principle of the advanced system. In this new DFB pilot plant, other gases like $\mathrm{CO}_{2}$ or gas mixtures of $\mathrm{CO}_{2}$ and steam are applied as gasification agents. The $\mathrm{CR}$ operates as a fast fluidized bed at typical temperatures from 900 to $970{ }^{\circ} \mathrm{C}$. The GR is designed for optimized sequential reaction conditions. The objectives are a high fuel conversion in the GR, a high product gas quality, and the reduction of the undesirable tar content. This is especially important for biogenic residues and waste fuels that are typically characterized by a higher degree of tar in the product gas [13-15]. Therefore, the 900 to $950{ }^{\circ} \mathrm{C}$ hot upper part of the GR is a fluidized bed column with an overall countercurrent flow of the raw product gas from the

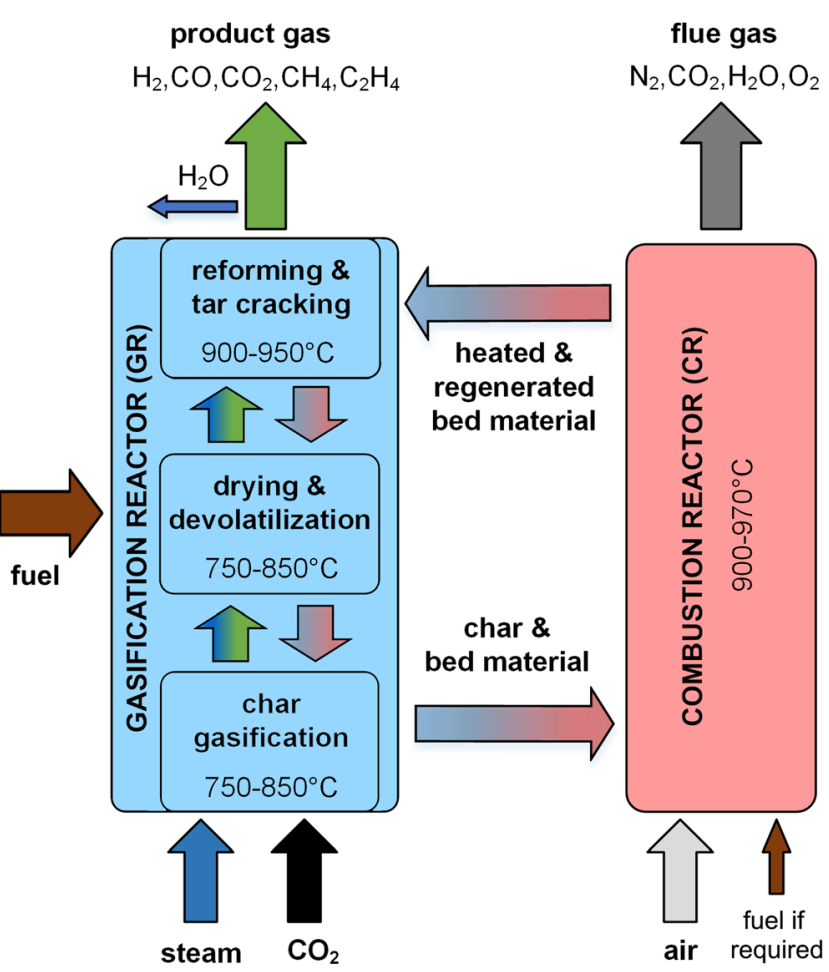

Fig. 2 Basic principle of the advanced DFB gasification 
lower part and the hot bed material from the CR. In addition, the lower GR operates as a bubbling fluidized bed at 750$850^{\circ} \mathrm{C}$ and is optimized for an effective devolatilization of different fuel types and an increased gasification efficiency of the char with the fluidization/gasification agent. The increase in the residence time for the char in the GR is an important issue, especially for the use of $\mathrm{CO}_{2}$ as a gasification agent. How these modifications influence the gasification process and the product gas composition is the topic of the present publication. The results of the advanced DFB gasification system from TU Wien include variations of the following:

- fuel type,

- bed material type,

- gasification agent,

- temperature, and

- steam-to-carbon ratio,

which aim for improved product gas quality, low tar content, and relevant key performance indicators regarding optimized process operation.

\section{Description of the advanced dual fluidized bed gasifier}

\subsection{General description}

The advanced reactor design was developed with the goal of increasing residence times and intensifying the contact between the introduced fuel, the volatiles, and the bed material in order to support the gasification reactions, improve conversion rates, and minimize the tar content in the product gas. This was realized through a new design of the GR. In particular, the upper part of the GR is divided into a sequence of sections, which ensures improved gas-particle interaction using flow obstacles in defined height intervals, as reported by Schmid et al. [16] and Pfeifer et al. [17]. The advanced pilot plant went into operation in 2014. Schmid [18] and Diem [19] document the development, engineering, and construction of the new plant in detail. The sketch in Figure 3 indicates the main dimensions and gives information regarding fluidization and fuel inputs. Additionally, Figure 3 illustrates all locations of the temperature and pressure sensors (indicated by red crosses) of the fluidized bed reactor system and shows the assembly of the main heat-resistant stainless steel parts with a three-dimensional (3D) drawing. Important temperature measurement points are highlighted and labeled. The fuel input is realized via on-bed feeding onto the bubbling fluidized bed of the lower part of the GR. A water-cooled screwconveyor followed by a free falling fuel input is installed. This enables fuel feeding without contacting the hot walls. Therefore, the system enables the feeding of fuels with low melting temperatures (like plastics). Inside the lower part of the GR, drying and devolatilization of the initial fuel and the gasification of char with the gasification agent occur. Bed material together with residual char is transported via the lower loop seal (LLS) to the fast fluidized CR. The LLS includes a coarse ash discharge for ash-rich alternative fuels. Inside the $\mathrm{CR}$, the bed material is heated up and regenerated by burning the char with air. If required, additional fuel can be introduced. A staged air input enables the adjustment of the global bed material circulation rate independent of the amount of oxygen required for complete combustion. The flue gas stream is released at the upper end of the CR, which is followed by a gravity separator for the separation of bed material particles. The separated particles from the CR reenter the GR via the upper loop seal (ULS). The upper GR is a countercurrent column with hot bed material flowing downwards and product gas streaming upwards, creating a countercurrent flow. A local bed material holdup is realized with constrictions, causing locally smaller reactor cross-sections and therefore higher superficial gas velocities to form a cascade of turbulent fluidization regimes. An enhanced gas-solid contact and higher residence time in these turbulent fluidized zones promote tar cracking and reforming reactions, especially by using catalytic bed materials, such as olivine or calcium oxide [20]. In addition, the product gas line leaving the GR is also equipped with a gravity separator, which recycles solids like bed material particles and fly char via the internal loop seal (ILS). All these factors increase the conversion efficiency. The gravity separators of the GR and CR allow smoother separation in contrast to cyclones. Working with low gas and particle velocities enables the use of softer bed materials like limestone without limitation. Attrition and abrasion effects are minimized for used bed materials. Downstream cyclones separate fine particles for each reactor to obtain a product gas and a flue gas with low dust concentration. The LLS and the ULS connect the two reactors and close the global circulation of bed material particles. The internal circulation in the GR is realized through the ILS. Additional fuel into the CR mainly compensates for the relatively high specific heat losses caused by the size of the pilot plant and enables control of the gasification temperature during gasification experiments. The design of the GR allows for the gasification of various fuels. More detailed explanation of the experimental setup and results from the first cold flow and gasification test runs can be found in the literature [21-23].

The pilot plant is designed to gather meaningful results from test runs during steady-state operation phases. The measured product gas composition, volume flows, temperatures, pressures, and other parameters are recorded continuously. Screens in the control room visualize measured data like actual values, diagrams, threshold values, and status signals online. After the experimental test runs, mean values are calculated via post processing from the measurement results within 
Fig. 3 Sketch indicating the dimensions and measurement points (left) and a 3D drawing of the advanced $100 \mathrm{~kW}$ pilot plant without thermal insulation (right)
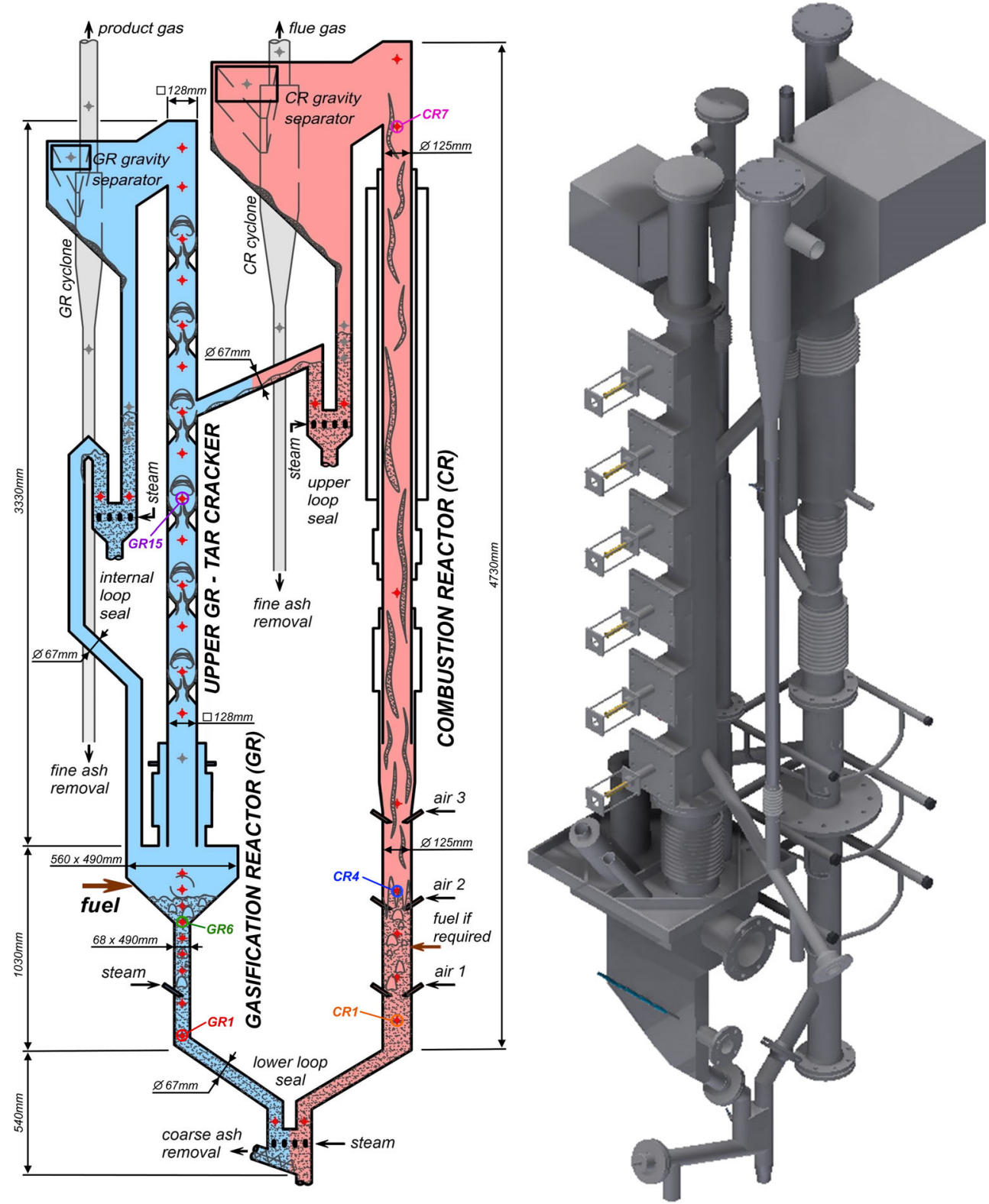

specific periods. To enable the calculation of descriptive mass and energy balances and to allow for other measurement procedures in a proper way, steady-state operation phases of the pilot plant are crucial. Figure 4 presents the temporal courses of the selected temperatures (cf. Figure 3) along the height of the DFB reactor system during a typical gasification test run. After the heating up procedure, the plant is switched to steam gasification. The aspired steady-state gasification operation is reached after a tuning phase. All results presented in this review correspond to operation phases. In Figure 4, it is shown that at the top of the CR, temperatures of approximately 950 $970{ }^{\circ} \mathrm{C}$ are reached, which is indicated by T CR7. Consequently, in the upper GR, similar temperatures occur (T GR15), because of the bed material input from the CR. In the lower GR, temperatures drop down to $790-830{ }^{\circ} \mathrm{C}$.
The energy needed for heating up, drying, devolatilization, and the gasification process of the fuel is visible by the consumption of heat leading to lower temperatures. The design of the plant allows fuel hoppers to be refilled or other equipment to be maintenanced during operation. An experimental daily test run lasts ca. 12 to $18 \mathrm{~h}$ including the heat up and shut down procedures and different steady-state phases that can run up to $8 \mathrm{~h}$.

In Figure 3, the fluidized bed reactor system made of heat-resistant stainless steel (1.4841, DIN EN 10095) for the production of two gas streams (product gas and flue gas) is presented as the heart of the pilot plant at TU Wien. Figure 5 shows the basic flow sheet of the overall pilot plant. The hopper and fuel feeding system are essential in ensuring smooth operation of the fluidized 


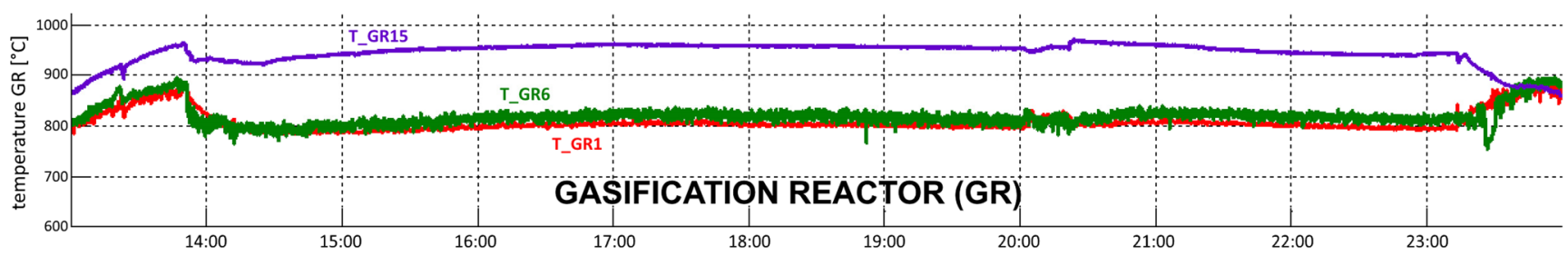

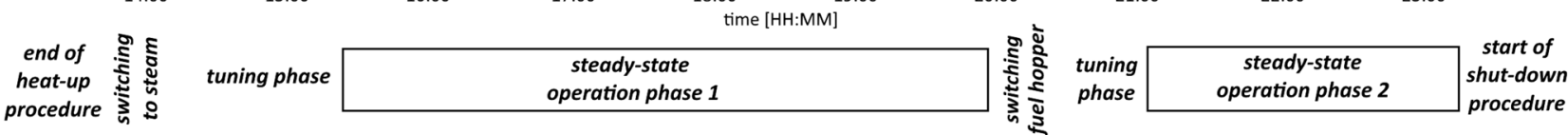

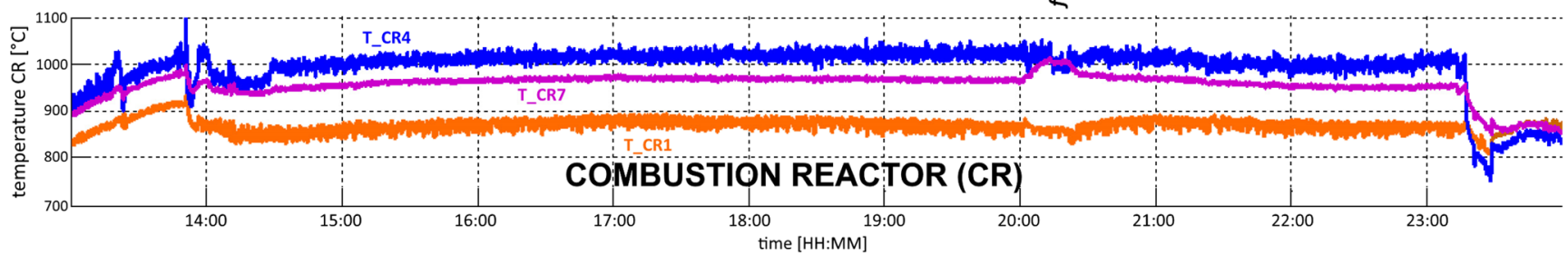

Fig. 4 Typical course of the temperature over time in the GR and CR during the gasification of softwood

bed reactor system. Special arrangements of the screws, cooling jackets, and two hoppers for mixing different fuels are available. Special equipment enables bed material sampling from different locations. Coarse and fine ash removal systems via screws and closed ash containers are implemented. The product and flue gases from the fluidized bed reactor system are analyzed and subsequently burned in a secondary combustion chamber. Different types of heat exchangers are installed at crucial spots in the system to enable the desired process conditions and to cool the gas streams. The heat is transferred to an unpressurized water-steam cycle. A fabric filter cleans the off-gas before it is forwarded to the stack. The entire pilot plant requires a height of $7 \mathrm{~m}$ and two floors with a base area of $35 \mathrm{~m}^{2}$ each [18]. The control and measurement of all relevant fluid input flows of air and steam and the visualization of the programmable logic controller (PLC) are integrated in the

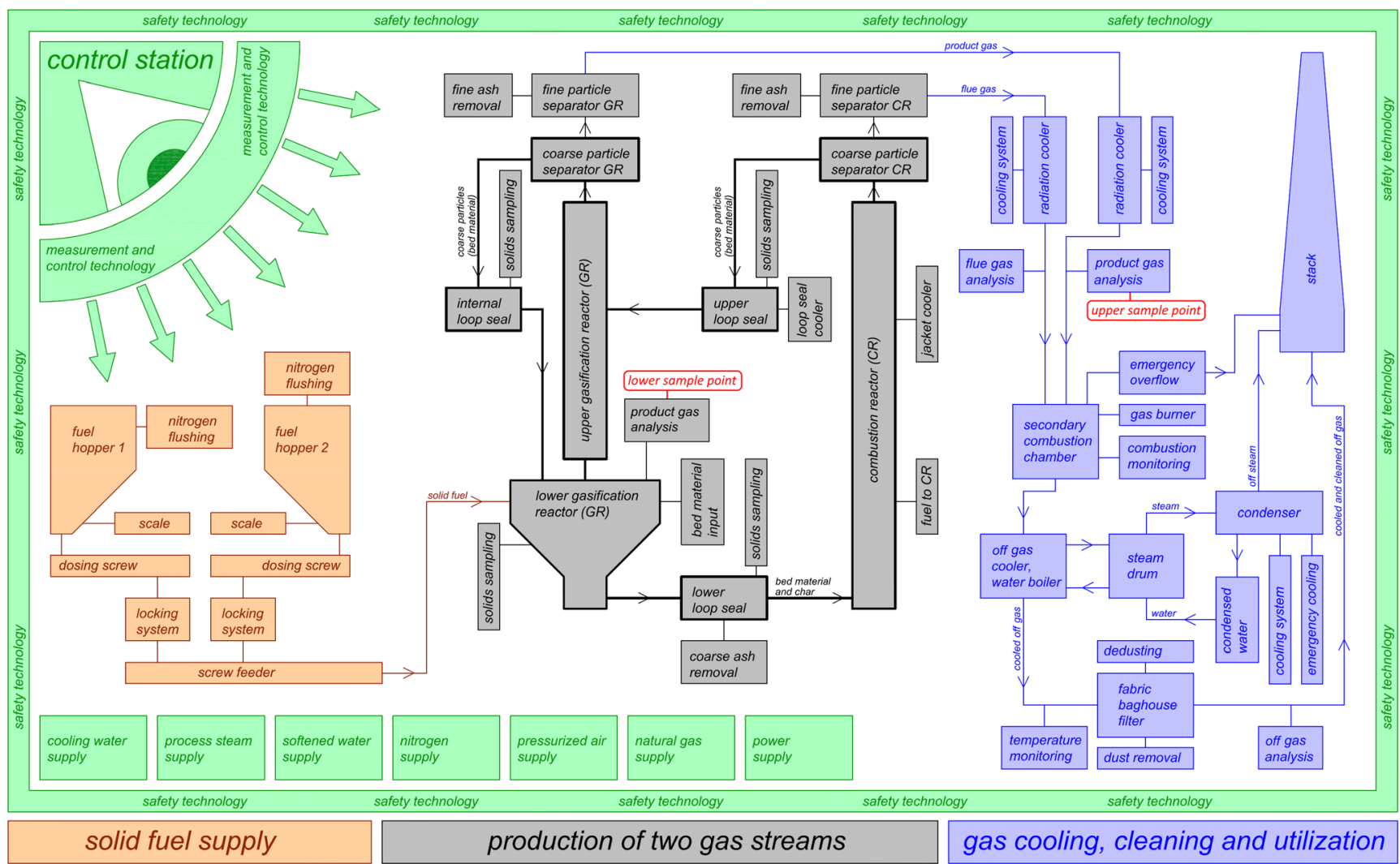

Fig. 5 Basic flow sheet as an overview of the overall advanced $100 \mathrm{~kW}$ pilot plant at TU Wien 
control room. The pilot plant with thermal insulation is shown in Figure 6 and Figure 7.

\subsection{Fluid dynamics of the advanced reactor design}

The advanced design mainly aims for a prolonged residence time of the bed material and an increased gas-solid contact in the GR. These goals are reached by the unique design of the upper GR. This part is a column equipped with constrictions. Thus, the gas velocity is increased due to a decreased crosssectional surface area at the height of every constriction. Consequently, a particle holdup of the down flowing bed material can be reached at every section above a constriction. The mechanism and a qualitative sketch of the pressure drop, pressure gradient, and solid volume fraction over the height of such a reactor design are displayed in a schematic figure (Figure 8). At the height of every constriction, an increased pressure drop is observed, and a staircase-shaped profile is obtained. By calculating the pressure gradient, the highest gradient occurs directly at the flow constriction, and the particle concentration is highest just above the flow constrictions. The obvious particle acceleration effects in the constriction region can explain the deviation of the pressure gradient and solid density $[16,24]$. The particles take up kinetic energy in the constriction region, which results in an increased pressure drop. In the low gas velocity sections between the constrictions, particles fall back mainly along the wall.

Extensive cold flow model experiments with different generations of acrylic glass models were conducted as a basis for the design of the advanced reactor system [16, 24, 25]. The design study led to a specific cold flow model, which is presented with Figure 9. It was built for deeper investigations on the fluid dynamics of the advanced concept [26-29]. Dimensionless similarity numbers are important for comparing the fluid dynamics of cold flow models with the

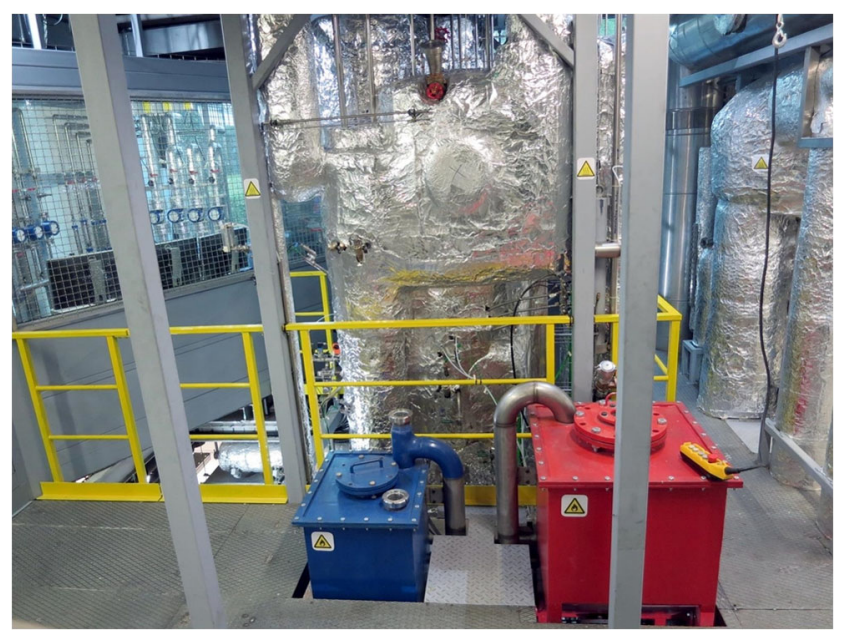

Fig. 6 Picture of the pilot plant with thermal insulation and control room (upper floor)

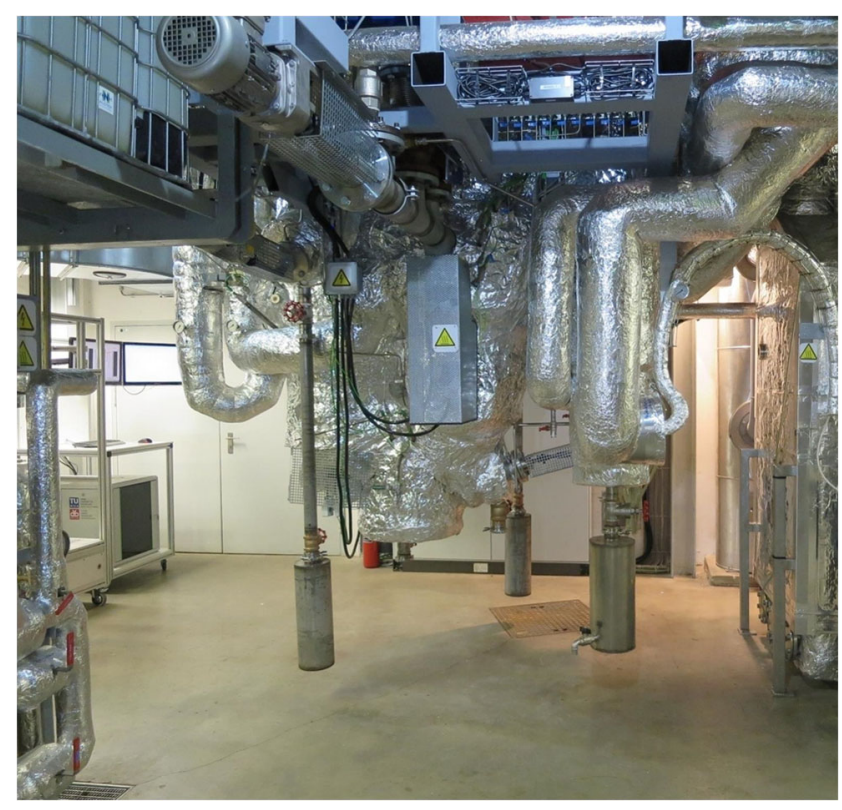

Fig. 7 Picture of the pilot plant with thermal insulation and ash containers (lower floor)

fluidization behavior inside a gasifier under hot operation conditions. Therefore, similarity numbers like the dimensionless particle diameter $d_{\mathrm{p}} *$ (Eq. (1)), the relative density $\left(\rho^{*}\right)$ as the density ratio between the fluidization agent and the density of the bed material (Eq. (2)), or the dimensionless fluidization velocity $U^{*}$ (Eq. (3)) must be in the same range. This is the reason why bronze particles are used as the bed material in airblown cold flow models. The relative density between bronze and air in ambient conditions is in the range of the relative density between olivine or calcite as bed material and the fluidization gas in the hot facility with temperatures around $800{ }^{\circ} \mathrm{C}[18]$.

$$
\begin{aligned}
& d_{\mathrm{p}}{ }^{*}=d_{\mathrm{p}}\left(\frac{g\left(\rho_{\mathrm{p}}-\rho_{\mathrm{g}}\right)}{\nu^{2} \rho_{\mathrm{g}}}\right)^{1 / 3}=A r^{1 / 3} \\
& \rho^{*}=\frac{\left(\rho_{\mathrm{p}}-\rho_{\mathrm{g}}\right)}{\rho_{\mathrm{g}}} \\
& U^{*}=U\left(\frac{\rho_{\mathrm{g}}}{\nu \mathrm{g}\left(\rho_{\mathrm{p}}-\rho_{\mathrm{g}}\right)}\right)^{1 / 3}=\frac{\operatorname{Re}}{A r^{1 / 3}}
\end{aligned}
$$

With a minimum of two calculated dimensionless similarity numbers, it is possible to determine an operating point of a specific fluidized bed condition (fluid dynamics) in a fluidization regime map. In 1986, Grace [30] presented a practical gas-solid fluidization map based on the work of Reh [31] in 1961. The map used an arrangement of dimensionless numbers, which were 
Fig. 8 Schematic figure of typical qualitative pressure drop, pressure gradient, and solid fraction in the upper GR with zones of improved gas-solid interaction [24]

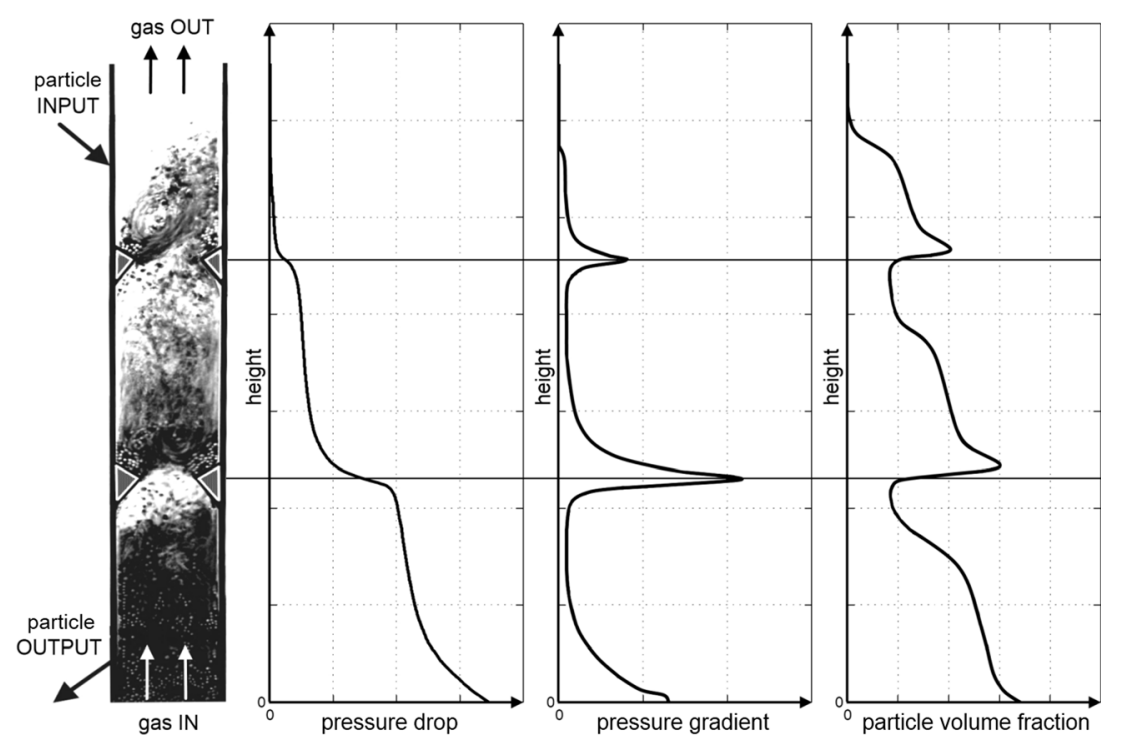

explicit and significant for the fluidization velocity on the vertical axis as an operational parameter $\left(U^{*}\right)$ and the particle diameters as a material property on the horizontal axis $\left(d_{\mathrm{p}} *\right)$. To show the fluid dynamic similarity between cold flow models, cold test runs, and real hot gasification test runs, a modified regime map can be used (Figure 10) from Schmid [18], which was updated in 2014 to reflect actual and historic data of various sources. The curves of minimum bubbling fluidization $U_{\mathrm{mb}}$ [32], minimum fluidization velocity $U_{\mathrm{mf}}$ [33], critical velocity $U_{\mathrm{c}}$ [18], and the velocity of significant entrainment $U_{\text {se }}$ [34] separate the regime regions from
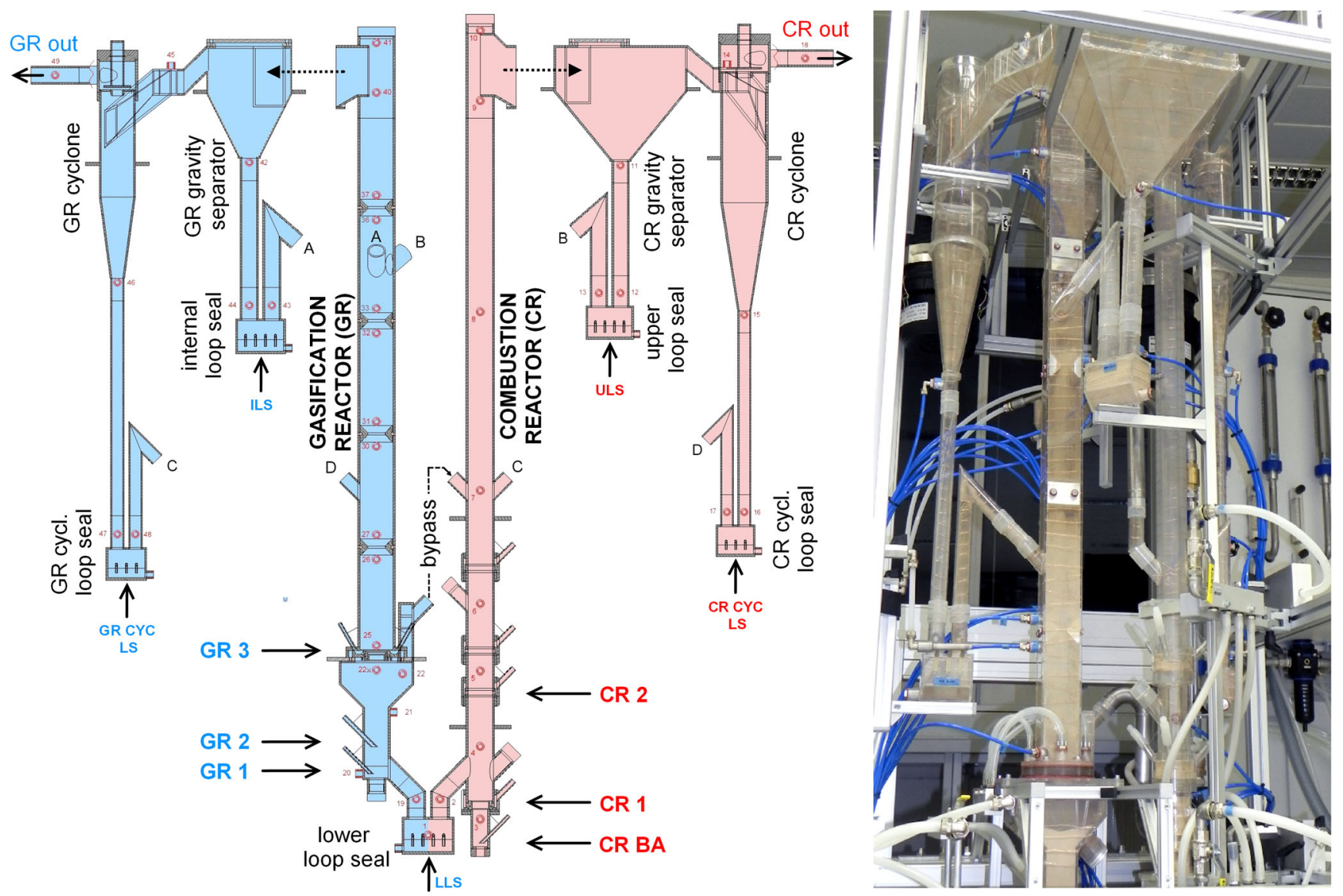

Fig. 9 Cold flow model of the advanced reactor concept [18] 
Fig. 10 Operating points inside a modified fluidization regime map [18] investigating the fluid dynamics of the advanced reactor design

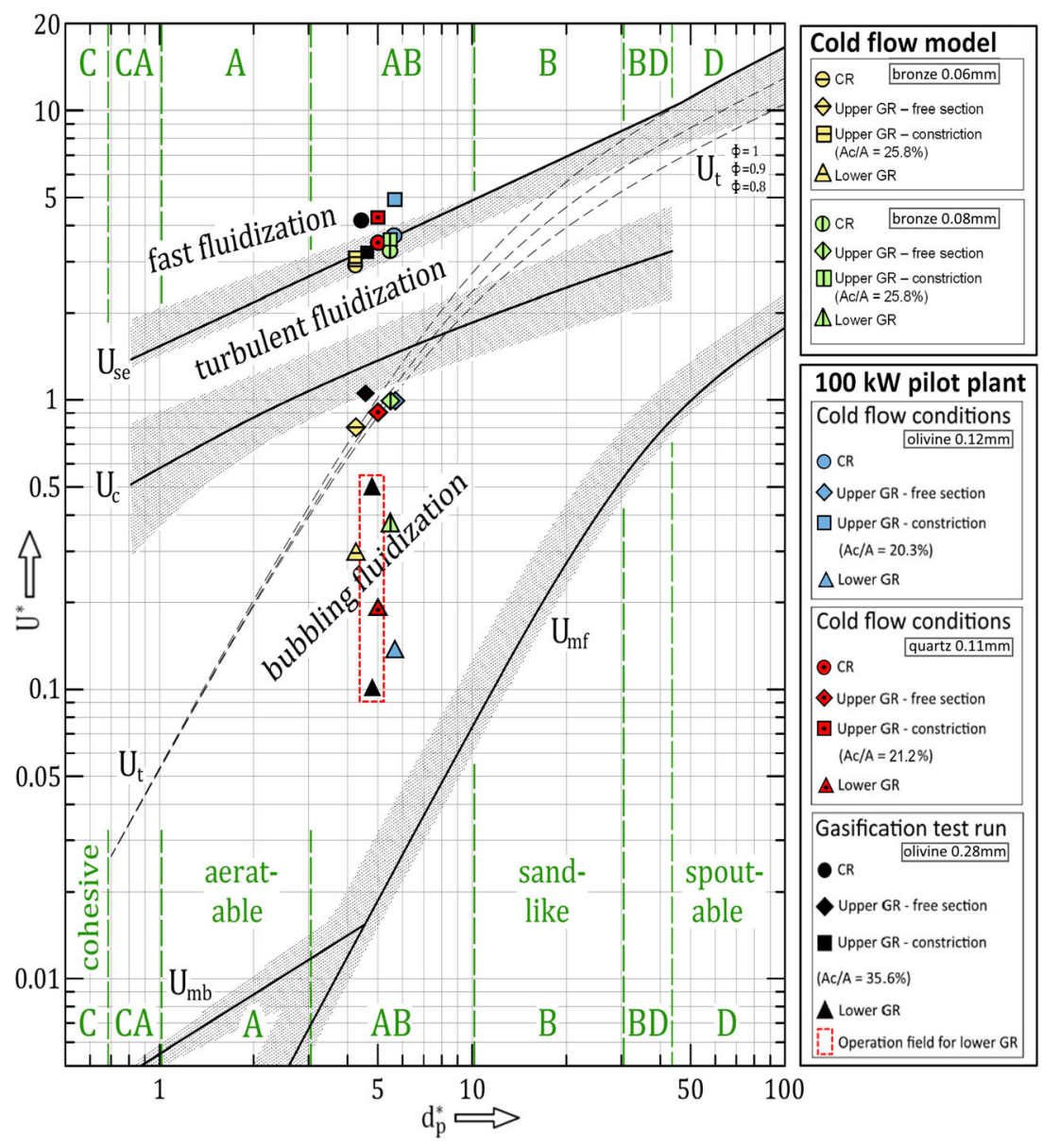

each other. It must be taken into account that the boundaries of regime regions have no sharp borders and the transition between them is smooth. In addition, the terminal velocity $U_{\mathrm{t}}$ for a single bed material particle is shown as a dashed curve for different sphericities $\Phi[35]$. For better understanding, Figure 11 (merged from [30, 36, 37]) shows schematic illustrations of the three main regimes, i.e., of bubbling, turbulent,
Fig. 11 Distribution of gas fluidized particles for three different fluidization regimes typically used in industrial applications
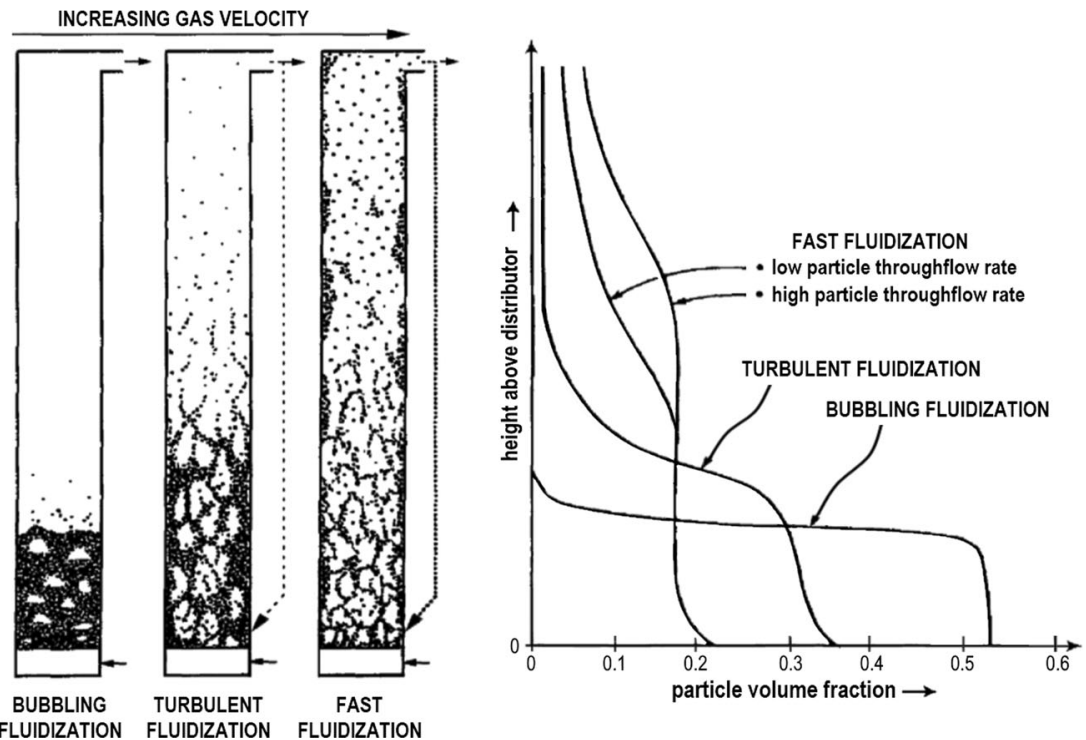
and fast fluidization of gas-solid fluid dynamics. Thus, Figure 10 provides an overview of typical GR and CR ambient operation conditions for the following:

- the cold flow model displayed in Figure 9 operated with bronze particles $\left(d_{\mathrm{p}}=0.06 \& 0.08 \mathrm{~mm}\right)$ as bed material and air as the fluidization agent $[27,38]$;

- cold flow investigations of the advanced $100 \mathrm{~kW}$ pilot plant shown in Figure 3 with olivine $\left(d_{\mathrm{p}}=0.12 \mathrm{~mm}\right)$ and quartz $\left(d_{\mathrm{p}}=0.11 \mathrm{~mm}\right)$ as bed material and air as the fluidization agent $[39,40]$; and

- a typical hot gasification test run with olivine $\left(d_{\mathrm{p}}=\right.$ $0.28 \mathrm{~mm}$ ) as the bed material [21].

When looking at the depicted operation points in the regime map of Figure 10, one can see that the lower GR typically operates as a bubbling fluidized bed, whereas in the constrictions of the upper GR, flow conditions on the border from turbulent to fast fluidization are typically present. At the same time, the free cross-sectional zones of the upper GR operating near the border from bubbling to turbulent fluidization. Thus, the flow regime of the countercurrent upper GR oscillates from the upper end of bubbling fluidization (free cross-section) to the lower end of fast fluidization (constricted cross-section) along the reactor height. This behavior indicates a turbulent regime in the particle accumulations directly above each constriction. The operation point of the CR should be typically located in the area of fast fluidization. As previously mentioned in Section 2.2, fluid dynamics similarity is an important issue for scaling the fluidized beds. The use in Figs. 10 and 11 represents a simplified method to show and compare operational behavior. For a deeper insight on the complex rules of similarity and scaling relationships, the studies by Geldart [41], Yang [42], and Glicksman et al. $[43,44]$ are recommended. The extensive test runs also lead to a deep knowledge about the entrainment of particles in the CR. It was possible to derive the global circulation rate of the bed material by analyzing specific pressures in the CR. Fuchs et al. [45] proposed a new method for determining the entrained mass flow in the advanced pilot plant using simple pressure measurements.

\subsection{Online measurement equipment}

A large number of temperature (type $\mathrm{K}$ thermocouples) and pressure sensors (Kalinsky DS2) enable an effective process control. The measuring lines of the pressure sensors are flushed continuously with very small $\mathrm{N}_{2}$ flow without influencing the measured value; this prevents sensor damage or condensation of tar and steam inside the measuring lines. Approximately 40 measurement points of the fluidized bed reactor system are visible in Figure 3. The overall pilot plant comprises more than 100 temperature and 70 pressure measurements. High-quality flow meters from the company Krohne measure all fluid input streams. Special measuring orifices from the company Barthel-Armaturen determine the two gas output flows (flue gas and product gas). Main product gas components like $\mathrm{H}_{2}, \mathrm{CO}, \mathrm{CO}_{2}, \mathrm{CH}_{4}$, and $\mathrm{O}_{2}$ are analyzed continuously by Rosemount NGA2000 measurement equipment. $\mathrm{C}_{2} \mathrm{H}_{2}, \mathrm{C}_{2} \mathrm{H}_{4}, \mathrm{C}_{2} \mathrm{H}_{6}, \mathrm{C}_{3} \mathrm{H}_{8}, \mathrm{~N}_{2}$, and $\mathrm{O}_{2}$ values are measured with a PerkinElmer ARNEL-Clarus 500 gas chromatograph every $12 \mathrm{~min}$. In parallel to the NGA2000 online measurement, the gas chromatograph also measures $\mathrm{CO}, \mathrm{CO}_{2}$, and $\mathrm{CH}_{4}$. Two permanent sample points are installed at the pilot plant to measure the gas composition at different positions (cf. Figure 5). Thus, the product gas composition is measurable both (a) directly in the freeboard above the bubbling bed of the

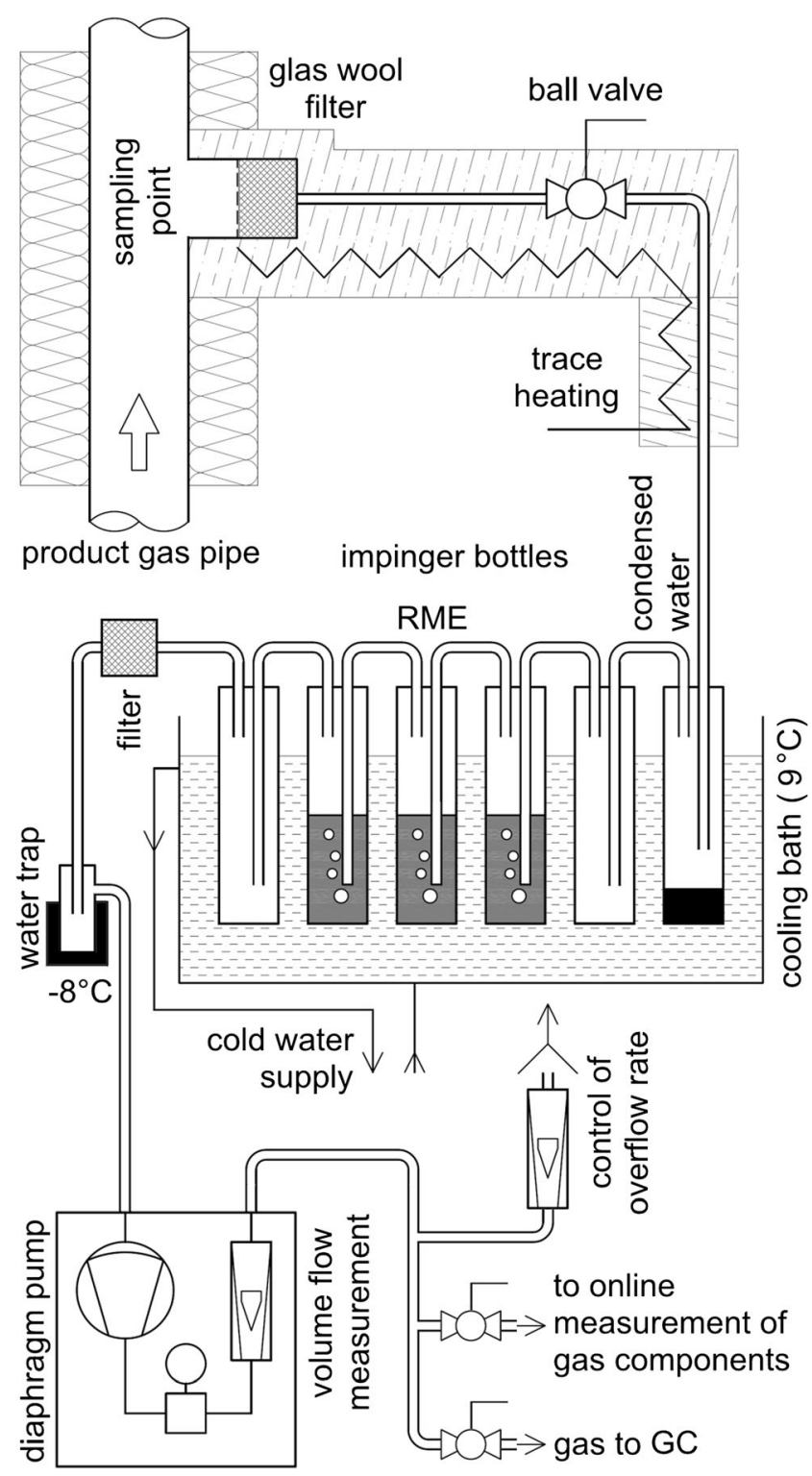

Fig. 12 Gas cleaning setup for the online measurement of gas components [48] 
lower GR (lower sample point) and (b) in the product gas pipe subsequent to the upper GR after the solid separators and the radiation cooler (upper sample point). As presented in Figure 12, the product gas must be cleaned to protect the measurement devices from contaminants. The product gas is filtered and washed with cooled rapeseed methyl ester (RME) to eliminate condensable components like water and tar. The flue gas components $\mathrm{CO}_{2}, \mathrm{O}_{2}, \mathrm{CO}, \mathrm{NO}, \mathrm{NO}_{2}, \mathrm{~N}_{2} \mathrm{O}$, and $\mathrm{SO}_{2}$ of the $\mathrm{CR}$ are measured with a Rosemount NGA2000 in a similar way. In addition, the off gas to the stack after the secondary combustion chamber is analyzed continuously (cf. Figure 5) for $\mathrm{CO}, \mathrm{CO}_{2}$, and $\mathrm{O}_{2}$ concentrations with another Rosemount NGA2000 device. A high-quality industrial programmable logic controller (PLC) from the company B\&R is used for the automation of the pilot plant and includes important safety measures. This PLC continuously records all important flow rates, pressures, temperatures, etc., as well as the main product gas components. Detailed descriptions of the measurement devices and control technology can be found in literature [38, 46, 47]. Figure 13 (modified from [47]) shows an overview of the important gas measurement equipment for the online control of process parameters.

\subsection{Offline measurement equipment}

It is challenging to obtain reproducible and meaningful measured data related to the gas analysis of gasification processes. A current guideline of IEA Bioenergy [49] extensively presents the complex procedures of online and offline measurements including the necessary gas preconditioning in detail. The certified Test Laboratory for Combustion Systems at TU Wien conducted the tar sampling for all presented tar measurements. The measurement procedure followed a method based on the official standard CEN/TS 15439:2006 based on the tar protocol [50]. All samples were analyzed twice. First, the concentration of gravimetric tar was determined, and, second, the concentration of single tar components was determined by using a gas chromatography coupled with mass spectrometry (GC-MS). Typically, isopropanol is used as a solvent. Nevertheless, for measurements at the advanced pilot plant, toluene is the standard solvent, because the solubility of tar in toluene is generally slightly higher, and the water (steam) content in the product gas can be measured simultaneously. Figure 14 shows the standardized arrangement of sampling equipment used to analyze the content of dust, char, water, and tar in the product gas stream. The sampling procedure takes $8 \mathrm{~min}$ for typical tar contents and up to $16 \mathrm{~min}$ if the tar content is very low. With this setup, the detection of toluene is impossible and the detection of benzene and xylene is not easy. Therefore, GC-MS tar values presented in this paper are the sum of the single GC-MS tar components, i.e., without benzene, toluene, ethylbenzene, and xylene (BTEX). If it was possible to detect benzene, the value is given separately. Wolfesberger et al. [51] describe the exact applied method of tar measurement at TU Wien. There are different ways to categorize tar components. Clear classifications of single tar components are described in detail elsewhere [52-55]. The experimental results presented are
Fig. 13 Online measurement equipment, PLC, and data storage system

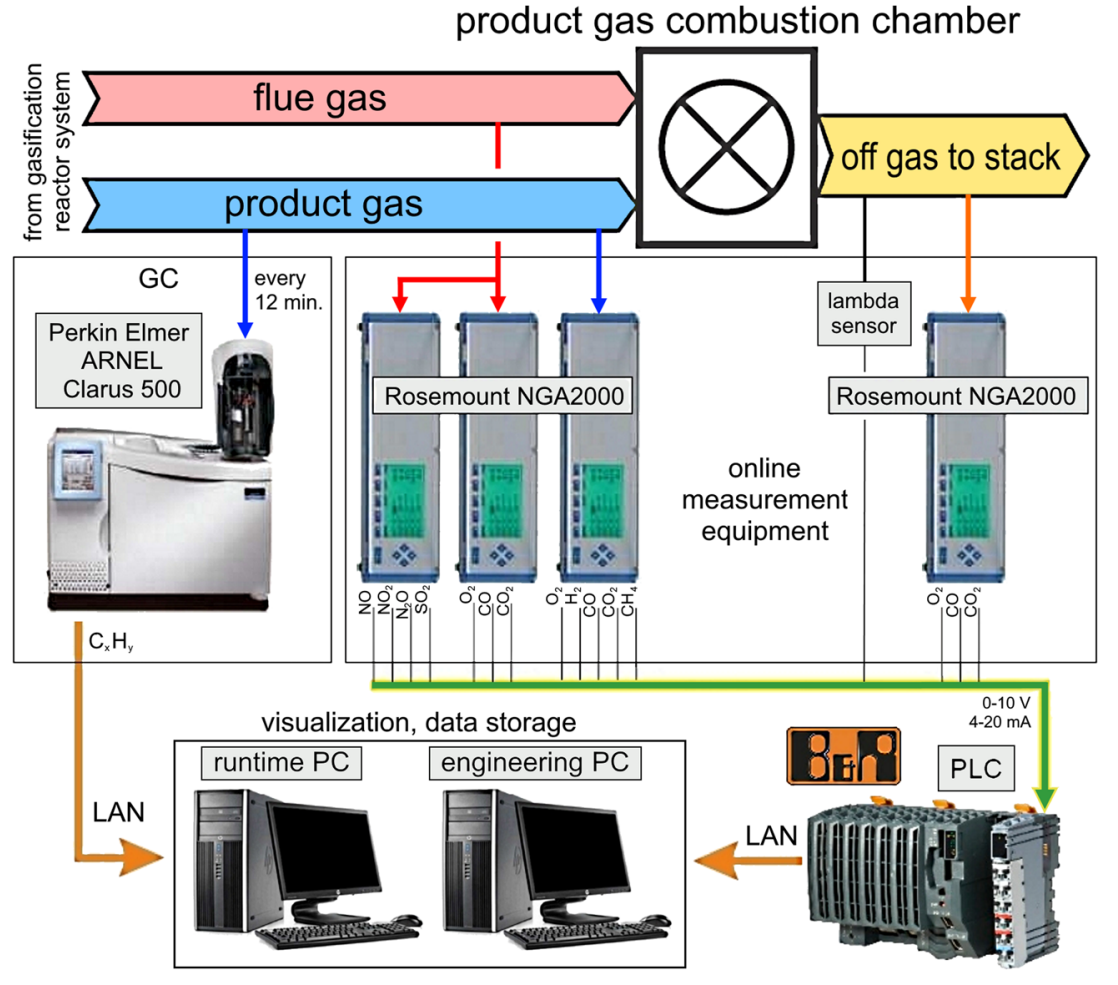




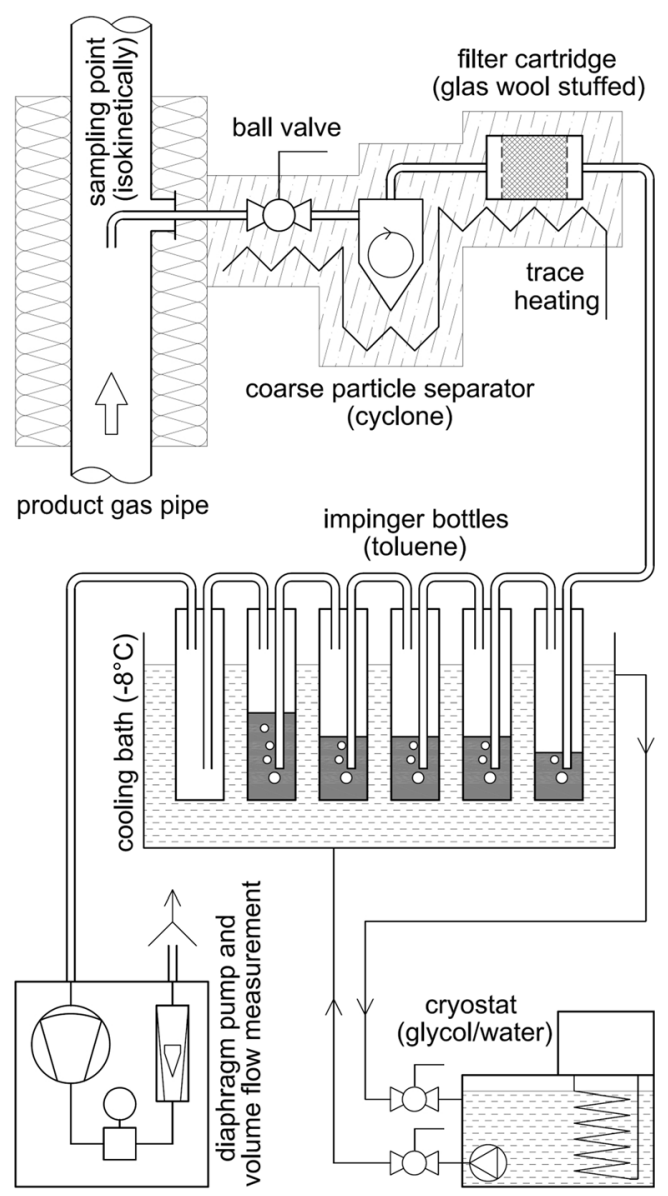

Fig. 14 Tar sampling setup to determine the tar content in the product gas and to analyze tar components [8]

average values of each series of samples. Table 1 shows a measurement report with all single GC-MS-accessible tar components at TU Wien as an overview. The results are from a gasification test run with bark as fuel and limestone as bed material. During steady-state operation of the gasification process, one sample procedure was performed with toluene while the other used isopropanol as a solvent for comparison. Clearly, the results are very similar. Naphthalene, acenaphthylene, and anthracene are the main GC-MS tar components. After the high-temperature upper GR, most of the considered single components are not present anymore in the product gas stream, especially primary tar components like hazardous phenols. In addition, Table 1 shows the BTEX contents. No xylenes were detectable, and the single toluene measurement shows a value that is slightly more than half of the value of benzene.

A very similar standardized sample procedure enables the determination of ammonia $\left(\mathrm{NH}_{3}\right)$, hydrogen sulfide $\left(\mathrm{H}_{2} \mathrm{~S}\right)$, and hydrogen chloride $(\mathrm{HCl})$ in the product gas. These contents mainly originate from the elemental composition of the fuel itself. The sample arrangement is the same as that for tar (cf. Figure 14) but with other specific solvents. Thus, it is not possible to measure $\mathrm{NH}_{3}, \mathrm{H}_{2} \mathrm{~S}$, and $\mathrm{HCl}$ at the same time due to different solvents being needed for the sampling procedure. If available, a second gas chromatograph (PerkinElmer) can determine product gas components of $\mathrm{C}_{2} \mathrm{H}_{4}, \mathrm{C}_{2} \mathrm{H}_{6}, \mathrm{C}_{2} \mathrm{H}_{2}, \mathrm{~N}_{2}$, $\mathrm{O}_{2}, \mathrm{CO}, \mathrm{CO}_{2}, \mathrm{CH}_{4}, \mathrm{H}_{2} \mathrm{~S}, \mathrm{COS}, \mathrm{RSH}$, and $\mathrm{C}_{4} \mathrm{H}_{4} \mathrm{~S}$ batch-wise by using gas sample bags.

Another simple but effective option to assess the GC-MS tar content in the product gas is the online measurement of accessible product gas components. The decomposition of the double bond in $\mathrm{C}_{2} \mathrm{H}_{4}$ seems to follow mechanisms similar to the decomposition of aromatic hydrocarbons (tar). Therefore, the $\mathrm{C}_{2} \mathrm{H}_{4}$ content in the product gas turns out to become the best indicator for correlations with the GC-MS tar content. Figure 15 is based on several references and combines gasification test runs with woody and agricultural biomass, biogenic residues, different coal types, char, and co-gasification test runs of wood and coal $[9,56-58]$. The measurements are from different generations of $100 \mathrm{~kW}$ pilot plants at TU Wien and from a $15 \mathrm{MW}$ industrial plant in Senden, Germany. As Figure 15 shows, most of the GC-MS tar values, primarily from the gasification of biogenic fuel types, are in a narrow range between the dashed curves. The mean trend curve gives a good idea where tar contents in the product gas are expected if values of the $\mathrm{C}_{2} \mathrm{H}_{4}$ content are available.

\subsection{Fuel types, fuel feeding, and bed material}

The PLC controls the solid fuel input into the GR by the calibration curve of the dosing screws. In addition, the two fuel hoppers are equipped with scales. The hopper setup enables the fast change from one fuel type to another or the mixture of fuels with a variation in the mixing ratios during a single non-stop test campaign. Good pourability of the fuel is important in the hoppers. The volume flow of the generated product gas leaving the GR is directly linked to the mass flow of the fuel input. If there is a problem with unsteady fuel feeding, fluctuations of the product gas flow occur immediately. Therefore, dried fuels as pellets or granulate are favorable to guarantee a uniform input into the $100 \mathrm{~kW}$ pilot plant at TU Wien. It should be mentioned that the fuel does not need to be pelletized in terms of industrial-sized plants. The mass flow of the additional fuel into the $\mathrm{CR}$ is also measured via calibration of the dosing equipment and a scale in parallel.

The main elemental composition, volatiles, water, and ash content as well as the ash melting behavior of the fuels were analyzed according to international standards at the Test Laboratory for Combustion Systems at TU Wien. Table 2 presents the proximate and ultimate analyses of all solid fuel types relevant for this publication. It is clearly visible that the dry and ash-free biogenic fuels have very similar elemental carbon $(\mathrm{C})$ to hydrogen $(\mathrm{H})$ to oxygen $(\mathrm{O})$ ratios. By subtracting the ash content, the amount of the elements nitrogen $(\mathrm{N})$, sulfur $(\mathrm{S})$, and chlorine $(\mathrm{Cl})$ strongly depends on the specific fuel type. Low ash deformation temperatures are an 
Table 1 Example of a tar measurement report and an overview of the considered single tar components

General information

\begin{tabular}{|c|c|c|c|}
\hline Solvent & - & Toluene & Isopropanol \\
\hline Measurement point & - & After upper GR & After upper GR \\
\hline Gasified fuel & - & Bark (BA) & Bark (BA) \\
\hline Bed material & - & Limestone & Limestone \\
\hline Gasification temperature & ${ }^{\circ} \mathrm{C}$ & $\approx 748$ & $\approx 748$ \\
\hline Water content & $\%$ & 42 & n.d. \\
\hline Gravimetric tar & $\mathrm{g} / \mathrm{Nm}_{\mathrm{db}}^{3}$ & 0.74 & 0.62 \\
\hline Sum GC-MS tar & $\mathrm{g} / \mathrm{Nm}_{\mathrm{db}}^{3}$ & 2.12 & 2.03 \\
\hline \multicolumn{4}{|c|}{ Single GC-MS tar components } \\
\hline Phenylacetylene & $\mathrm{mg} / \mathrm{Nm}_{\mathrm{db}}^{3}$ & 0 & 0 \\
\hline Styrene & $\mathrm{mg} / \mathrm{Nm}_{\mathrm{db}}^{3}$ & 50 & 23 \\
\hline Mesitylene & $\mathrm{mg} / \mathrm{Nm}_{\mathrm{db}}^{3}$ & 0 & 0 \\
\hline Phenol & $\mathrm{mg} / \mathrm{Nm}_{\mathrm{db}}^{3}$ & 0 & 0 \\
\hline Benzofuran & $\mathrm{mg} / \mathrm{Nm}_{\mathrm{db}}^{3}$ & 0 & 0 \\
\hline $1 \mathrm{H}$-indene & $\mathrm{mg} / \mathrm{Nm}_{\mathrm{db}}^{3}$ & 75 & 40 \\
\hline 2-Methylphenol & $\mathrm{mg} / \mathrm{Nm}_{\mathrm{db}}^{3}$ & 0 & 0 \\
\hline 4-Methylphenol & $\mathrm{mg} / \mathrm{Nm}_{\mathrm{db}}^{3}$ & 0 & 0 \\
\hline 2-Methylbenzofuran & $\mathrm{mg} / \mathrm{Nm}_{\mathrm{db}}^{3}$ & 0 & 0 \\
\hline 2,6-Dimethylphenol & $\mathrm{mg} / \mathrm{Nm}_{\mathrm{db}}^{3}$ & 0 & 0 \\
\hline 2,5- and 2,4-Dimethylphenol & $\mathrm{mg} / \mathrm{Nm}_{\mathrm{db}}^{3}$ & 0 & 0 \\
\hline 3,5-Dimethylphenol & $\mathrm{mg} / \mathrm{Nm}_{\mathrm{db}}^{3}$ & 0 & 0 \\
\hline 2,3-Dimethylphenol & $\mathrm{mg} / \mathrm{Nm}_{\mathrm{db}}^{3}$ & 0 & 0 \\
\hline 3,4-Dimethylphenol & $\mathrm{mg} / \mathrm{Nm}_{\mathrm{db}}^{3}$ & 0 & 0 \\
\hline 2-Methoxy-4-methylphenol & $\mathrm{mg} / \mathrm{Nm}_{\mathrm{db}}^{3}$ & 0 & 0 \\
\hline Naphthalene & $\mathrm{mg} / \mathrm{Nm}_{\mathrm{db}}^{3}$ & 1464 & 1486 \\
\hline 1-Benzothiophene & $\mathrm{mg} / \mathrm{Nm}_{\mathrm{db}}^{3}$ & 0 & 0 \\
\hline Quinoline & $\mathrm{mg} / \mathrm{Nm}_{\mathrm{db}}^{3}$ & 0 & 0 \\
\hline 2-Methylnaphthalene & $\mathrm{mg} / \mathrm{Nm}_{\mathrm{db}}^{3}$ & 16 & 0 \\
\hline Isoquinoline & $\mathrm{mg} / \mathrm{Nm}_{\mathrm{db}}^{3}$ & 0 & 0 \\
\hline 1-Methylnaphthalene & $\mathrm{mg} / \mathrm{Nm}_{\mathrm{db}}^{3}$ & 0 & 0 \\
\hline 1-Vinylnaphthalene & $\mathrm{mg} / \mathrm{Nm}_{\mathrm{db}}^{3}$ & 0 & 0 \\
\hline 2-Vinylnaphthalene & $\mathrm{mg} / \mathrm{Nm}_{\mathrm{db}}^{3}$ & 0 & 0 \\
\hline 1-Indanone & $\mathrm{mg} / \mathrm{Nm}_{\mathrm{db}}^{3}$ & 0 & 0 \\
\hline Eugenol & $\mathrm{mg} / \mathrm{Nm}_{\mathrm{db}}^{3}$ & 0 & 0 \\
\hline Indole & $\mathrm{mg} / \mathrm{Nm}_{\mathrm{db}}^{3}$ & 0 & 0 \\
\hline Biphenyl & $\mathrm{mg} / \mathrm{Nm}_{\mathrm{db}}^{3}$ & 16 & 13 \\
\hline Isoeugenol & $\mathrm{mg} / \mathrm{Nm}_{\mathrm{db}}^{3}$ & 0 & 0 \\
\hline Acenaphthylene & $\mathrm{mg} / \mathrm{Nm}_{\mathrm{db}}^{3}$ & 131 & 109 \\
\hline Acenaphthene & $\mathrm{mg} / \mathrm{Nm}_{\mathrm{db}}^{3}$ & 38 & 39 \\
\hline Dibenzofuran & $\mathrm{mg} / \mathrm{Nm}_{\mathrm{db}}^{3}$ & 0 & 0 \\
\hline Fluorene & $\mathrm{mg} / \mathrm{Nm}_{\mathrm{db}}^{3}$ & 0 & 0 \\
\hline Dibenzothiophene & $\mathrm{mg} / \mathrm{Nm}_{\mathrm{db}}^{3}$ & 0 & 0 \\
\hline 2-Methylpyridine & $\mathrm{mg} / \mathrm{Nm}_{\mathrm{db}}^{3}$ & 0 & 0 \\
\hline 3- and 4-Methylpyridine & $\mathrm{mg} / \mathrm{Nm}_{\mathrm{db}}^{3}$ & 0 & 0 \\
\hline Anthracene & $\mathrm{mg} / \mathrm{Nm}_{\mathrm{db}}^{3}$ & 300 & 282 \\
\hline Phenanthrene & $\mathrm{mg} / \mathrm{Nm}_{\mathrm{db}}^{3}$ & 13 & 22 \\
\hline Carbazole & $\mathrm{mg} / \mathrm{Nm}_{\mathrm{db}}^{3}$ & 0 & 0 \\
\hline 4,5-Methylphenanthrene & $\mathrm{mg} / \mathrm{Nm}_{\mathrm{db}}^{3}$ & 0 & 0 \\
\hline
\end{tabular}


Table 1 (continued)

General information

\begin{tabular}{|c|c|c|c|}
\hline Solvent & - & Toluene & Isopropanol \\
\hline 9-Methylanthracene & $\mathrm{mg} / \mathrm{Nm}_{\mathrm{db}}^{3}$ & 0 & 0 \\
\hline Fluoranthene & $\mathrm{mg} / \mathrm{Nm}_{\mathrm{db}}^{3}$ & 12 & 8 \\
\hline Pyrene & $\mathrm{mg} / \mathrm{Nm}_{\mathrm{db}}^{3}$ & 8 & 6 \\
\hline Benzo[a]anthracene & $\mathrm{mg} / \mathrm{Nm}_{\mathrm{db}}^{3}$ & 0 & 0 \\
\hline Chrysene & $\mathrm{mg} / \mathrm{Nm}_{\mathrm{db}}^{3}$ & 0 & 0 \\
\hline Benzo[b]fluoranthene & $\mathrm{mg} / \mathrm{Nm}_{\mathrm{db}}^{3}$ & 0 & 0 \\
\hline Benzo[k]fluoranthene & $\mathrm{mg} / \mathrm{Nm}_{\mathrm{db}}^{3}$ & 0 & 0 \\
\hline Benzo[a]pyrene & $\mathrm{mg} / \mathrm{Nm}_{\mathrm{db}}^{3}$ & 0 & 0 \\
\hline Benzo[e]pyrene & $\mathrm{mg} / \mathrm{Nm}_{\mathrm{db}}^{3}$ & 0 & 0 \\
\hline Benzo[g,h,i]perylene & $\mathrm{mg} / \mathrm{Nm}_{\mathrm{db}}^{3}$ & 0 & 0 \\
\hline Dibenz[a,h]anthracene & $\mathrm{mg} / \mathrm{Nm}_{\mathrm{db}}^{3}$ & 0 & 0 \\
\hline Indeno[1,2,3-cd]pyrene & $\mathrm{mg} / \mathrm{Nm}_{\mathrm{db}}^{3}$ & 0 & 0 \\
\hline Perylene & $\mathrm{mg} / \mathrm{Nm}_{\mathrm{db}}^{3}$ & 0 & 0 \\
\hline Coronene & $\mathrm{mg} / \mathrm{Nm}_{\mathrm{db}}^{3}$ & 0 & 0 \\
\hline \multicolumn{4}{|c|}{ Single BTEX components } \\
\hline Benzene & $\mathrm{mg} / \mathrm{Nm}_{\mathrm{db}}^{3}$ & 6951 & 7464 \\
\hline Toluene & $\mathrm{mg} / \mathrm{Nm}_{\mathrm{db}}^{3}$ & n.d. & 3821 \\
\hline Ethylbenzene & $\mathrm{mg} / \mathrm{Nm}_{\mathrm{db}}^{3}$ & 0 & 0 \\
\hline $\mathrm{m}$ - and $\mathrm{p}$-Xylene & $\mathrm{mg} / \mathrm{Nm}_{\mathrm{db}}^{3}$ & 0 & 0 \\
\hline o-Xylene & $\mathrm{mg} / \mathrm{Nm}_{\mathrm{db}}^{3}$ & 0 & 0 \\
\hline
\end{tabular}

n.d., not determinable

indicator for sintering effects that may lead to the agglomeration of bed material particles. Agglomeration must be prevented in fluidized beds. Fuel ash sintering and melting is one of the biggest limitations for fluidized bed technology and is especially relevant when using alternative fuel types. The ash melting behavior is determined by the standardized characteristic temperature method. Two temperatures are specified - the deformation temperature, where the first rounding of the edges of a cubic sample occurs, and the flow temperature, where the sample is molten to a flat disk with defined geometrical conditions (specific height). In this context, hazelnut shells are a notable fuel with a problematic low ash deformation temperature of $720^{\circ} \mathrm{C}$. In contrast, fuel types with ash deformation temperatures higher than $1100{ }^{\circ} \mathrm{C}$ seem to be suitable for the thermochemical conversion in the fluidized bed reactor system.
Fig. 15 Relation between $\mathrm{C}_{2} \mathrm{H}_{4}$ and GC-MS tar content in the product gas

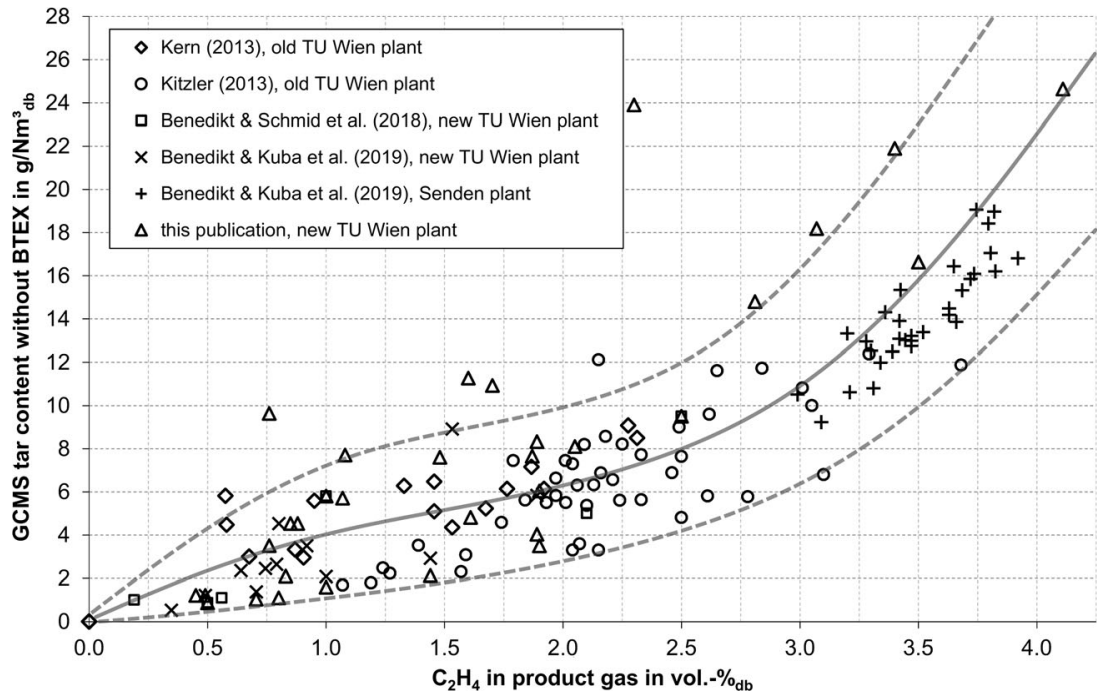


Table 2 Proximate and ultimate analyses of fuels for gasification test runs

\begin{tabular}{|c|c|c|c|c|c|c|c|c|c|c|c|}
\hline Parameter & Unit & Meas. accuracy $(\%)$ & SW & HNS & BA & $\mathrm{SCB}$ & $\mathrm{RH}$ & $\mathrm{BA}+\mathrm{CM}^{\mathrm{a}}$ & $\mathrm{CM}$ & $\mathrm{BA}+\mathrm{CM}+\mathrm{ST}^{\mathrm{b}}$ & LI \\
\hline Water content & $\mathrm{wt} \%$ & \pm 4.3 & 7.2 & 9.4 & 7.7 & 7.7 & 7.5 & 8.7 & 9.1 & 9.3 & 5.8 \\
\hline Ash content & $\mathrm{wt} \%_{\mathrm{db}}$ & \pm 9.2 & 0.2 & 1.5 & 7 & 2.3 & 15.2 & 12.9 & 25.4 & 12.5 & 9.1 \\
\hline Carbon (C) & $\mathrm{wt} \%_{\text {daf }}$ & \pm 1 & 50.8 & 52.7 & 52.3 & 48.9 & 51.2 & 51.5 & 50.1 & 51.8 & 57.2 \\
\hline Hydrogen $(\mathrm{H})$ & $\mathrm{wt} \%_{\text {daf }}$ & \pm 5 & 5.9 & 5,6 & 6.0 & 5.9 & 6.1 & 6.2 & 6.5 & 6.3 & 6.1 \\
\hline Nitrogen $(\mathrm{N})$ & $\mathrm{wt} \%_{\text {daf }}$ & \pm 5 & 0.200 & 0.37 & 0.342 & 0.409 & 0.554 & 1.964 & 5.509 & 1.490 & 1.860 \\
\hline Sulfur (S) & wt $\%_{\text {daf }}$ & \pm 7.5 & 0.005 & 0.027 & 0.053 & 0.051 & 0.071 & 0.225 & 0.664 & 0.150 & 0.145 \\
\hline Chlorine $(\mathrm{Cl})$ & wt $\%_{\text {daf }}$ & \pm 7.5 & 0.005 & 0.028 & 0.053 & 0.061 & 0.106 & 0.216 & 0.448 & 0.170 & 0.015 \\
\hline Oxygen $(\mathrm{O})^{*}$ & $\mathrm{wt} \%_{\text {daf }}$ & - & 43.1 & 41.3 & 41.3 & 44.7 & 42.0 & 39.9 & 36.8 & 40.1 & 34.7 \\
\hline Volatile matter & wt $\%_{\text {daf }}$ & \pm 0.45 & 85.6 & 76.4 & 77.7 & 85.7 & 80.7 & 80.8 & 90.6 & 79.9 & 74.4 \\
\hline Lower heating value, moist & $\mathrm{MJ} / \mathrm{kg}$ & \pm 1 & 17.4 & 17.3 & 16.6 & 16.3 & 14.5 & 14.9 & 12.4 & 15.0 & 18.8 \\
\hline Ash deform. temp. (A) & ${ }^{\circ} \mathrm{C}$ & - & 1330 & 720 & n.a. & 1180 & $>1350$ & 1240 & n.o. & 1180 & 1470 \\
\hline Ash flow temp. (D) & ${ }^{\circ} \mathrm{C}$ & - & 1440 & $>1500$ & n.a. & 1330 & n.o. & 1340 & $>1490$ & 1250 & 1490 \\
\hline
\end{tabular}

SW, softwood; HNS, hazelnut shells; BA, bark; SCB, sugarcane bagasse; RH, rice husk; CM, chicken manure; ST, straw; LI, lignin; n.o., did not occur; n.a., not analyzed

a $70 \% \mathrm{BA}$ and $30 \% \mathrm{CM}$ based on weight

${ }^{\mathrm{b}} 60 \% \mathrm{BA}$ and $25 \% \mathrm{CM}$ and $15 \%$ ST based on weight

${ }^{*}$ Calculated by difference to $100 \mathrm{wt} \%$ daf

The plant is equipped with a gas tight system to fill in the fine-grained bed materials. Typically, all the necessary bed material is fully introduced into the fluidized bed reactor system at the beginning of the heat-up procedure of the plant. If bed material loss occurs over time, it is possible to refill a defined mass of bed material during full operation. Table 3 presents the composition and properties of each used bed material type relevant for the current publication. Beside olivine, quartz, and feldspar, the investigations include limestone, which forms highly catalytic active calcium oxide $(\mathrm{CaO})$ present at temperatures above $800{ }^{\circ} \mathrm{C}$ in the $\mathrm{CR}$. However, limestone has poor properties in terms of abrasion resistance in comparison with olivine, quartz, and feldspar. However, an intermixture of limestone is favorable for the gasification process. The addition of 10-20\% limestone to the main bed material olivine seems to have the same effect as the activation $[59,60]$ or calcium/ash layer formation $[8,61]$ on olivine particles during long-term gasification operation at industrial plants. Therefore, most of the presented test runs were conducted with pure limestone or bed material mixtures with the addition of limestone.

\subsection{Process simulation via IPSEpro and calculation of key figures}

By using the process simulation software IPSEpro, mass and energy balances can be calculated based on process data that was stored during gasification test runs. IPSEpro is an equation-oriented process simulation software. It originates from the power plant sector and offers the user stationary process simulation. Furthermore, IPSEpro enables validating measured experimental data of overdetermined balancing systems. The validation of raw data uses the software module PSValidate of the IPSEpro program package. The process model is solved with a data adjustment algorithm that minimizes the weighted sum of the squares of the differences between redundant measured values. For the validation of each presented test run at steady-state conditions, a system model with more than 8500 variables must be solved. Thereby, several redundant values are defined with a permitted deviation for each value according to its expected measurement inaccuracy. Weber et al. [62] explain a similar validation approach with IPSEpro in more detail. Pröll and Hofbauer [63] developed a comprehensive model library for biomass gasification. It enables the user to calculate important values via mass and energy balances that cannot be measured directly. Müller et al. [64] presented a simulation flowsheet and further information.

By the use of process simulation, the following performance indicating key figures are calculated, which were also used in previous works on the advanced DFB steam gasification pilot plant by Benedikt et al. [46] and Müller et al. [61]. The steam-to-fuel ratio $\varphi_{\mathrm{SF}}$ yields the ratio of the amount of total steam from fluidization and fuel water to that of dry and ash-free fuel fed into the GR, as given by Eq. (4). The steamto-carbon ratio $\varphi_{\mathrm{SC}}$ is given in Eq. (5). It is used to enable a comparison between test runs of fuel types with different carbon content. The product gas yield PGY is presented in Eq. (6) and gives the ratio between the dry product gas volume flow to that of the dry and ash-free mass flow of fuel introduced into the GR. The steam-related water conversion $X_{\mathrm{H} 2 \mathrm{O}}$ shows the relation of water consumed and water introduced into the GR and is depicted in Eq. (7). Equation (8) gives the cold gas 
Table 3 Characteristics of bed materials used for gasification test runs

\begin{tabular}{llllll}
\hline Parameter & Unit & Limestone & Feldspar & Quartz & Olivine \\
\hline $\mathrm{Al}_{2} \mathrm{O}_{3}$ & $\mathrm{wt} \%$ & $0.1-0.3$ & $17.5-18.5$ & $0.07-0.1$ & - \\
$\mathrm{CaCO}_{3}$ & $\mathrm{wt} \%$ & $95.5-97.0$ & - & - & - \\
$\mathrm{Fe}_{2} \mathrm{O}_{3}$ & $\mathrm{wt} \%$ & $0.1-0.3$ & $0.04-0.05$ & $0.03-0.05$ & $8.0-10.5$ \\
$\mathrm{~K}_{2} \mathrm{O}$ & $\mathrm{wt} \%$ & - & $14.5-15.0$ & - & - \\
$\mathrm{MgCO}_{3}$ & $\mathrm{wt} \%$ & $1.5-4.0$ & - & - & - \\
$\mathrm{MgO}$ & $\mathrm{wt} \%$ & - & - & - & $48.4-50.0$ \\
$\mathrm{Na}_{2} \mathrm{O}$ & $\mathrm{wt} \%$ & - & $0.7-1.0$ & - & - \\
$\mathrm{SiO}_{2}$ & $\mathrm{wt} \%$ & $0.4-0.6$ & $65.0-66.0$ & $99.0-99.9$ & $39.4-42.0$ \\
Other trace elements & $\mathrm{wt} \%$ & $0.2-2.5$ & $0.3-2.3$ & $0.05-0.9$ & $0.3-3.0$ \\
$\mathrm{Hardness}$ & $\mathrm{Mohs}$ & 3 & 6 & 7 & 6.5 \\
$\mathrm{Sauter}$ mean diameter $\left(d_{\mathrm{p}}=d_{\mathrm{sv}}\right)$ & $\mathrm{mm}$ & 0.48 & 0.29 & 0.29 & 0.26 \\
Particle size range $\left(d_{\mathrm{p} 10}-\mathrm{d}_{\mathrm{p} 90}\right)$ & $\mathrm{mm}$ & $0.34-0.72$ & $0.24-0.40$ & $0.23-0.50$ & $0.20-0.34$ \\
Particle density & $\mathrm{kg} / \mathrm{m}^{3}$ & $2650,1500^{\mathrm{a}}$ & 2600 & 2650 & 2900 \\
\hline
\end{tabular}

${ }^{\text {a }}$ Particle density after full calcination efficiency $\eta_{\mathrm{CG}}$, which describes the ratio of chemical energy in the product gas to the chemical energy in the fuel that is fed into the GR, based on the lower heating value. $\eta_{\mathrm{CG}}$ is a pure chemical energy ratio. Equation (9) describes the overall cold gas efficiency $\eta_{\mathrm{CG}, \mathrm{o}}$, which is an extension of the cold gas efficiency. $\eta_{\mathrm{CG}, \mathrm{o}}$ comprises the possibility to compare scientific test results from plants with very high specific heat losses with that of industrial sized plants having very low specific heat losses. The mean radiative heat loss of the insulated $100 \mathrm{~kW}$ stainless steel pilot plant for a typical test run is ca. $20-30 \mathrm{~kW}$ (20-30\% of the GR fuel input power). An industrial-sized plant with $15 \mathrm{MW}$ fuel power typically has a ten times lower specific radiative heat loss of $2-4 \%$ over the refractory-lined and good-insulated fluidized bed reactor system. Thus, $\eta_{\mathrm{CG}, \mathrm{o}}$ also considers the fuel fed into the GR as well as the relatively high specific radiating heat losses of the $100 \mathrm{~kW}$ pilot plant and, therefore, indicates the potential value of the overall efficiency with zero radiative heat losses.

$$
\begin{aligned}
\varphi_{\mathrm{SF}} & =\frac{\dot{m}_{\text {steam }, \mathrm{GR}}+\dot{m}_{\mathrm{H} 2 \mathrm{O}, \mathrm{GR}, \text { fuel }}}{\dot{m}_{\mathrm{GR}, \text { fuel,daf }}} \\
\varphi_{\mathrm{SC}} & =\frac{\dot{m}_{\text {steam }, \mathrm{GR}}+\dot{m}_{\mathrm{H} 2 \mathrm{O}, \mathrm{GR}, \text { fuel }}}{\dot{m}_{\mathrm{C}, \mathrm{GR}, \text { fuel }}} \\
P G Y & =\frac{\dot{V}_{\mathrm{PG}}}{\dot{m}_{\mathrm{GR}, \text { fuel,daf }}} \\
X_{\mathrm{H} 2 \mathrm{O}} & =\dot{m}_{\mathrm{steam}, \mathrm{GR}}+\frac{\dot{m}_{\mathrm{H} 2 \mathrm{O}, \mathrm{GR}, \text { fuel }}-\dot{m}_{\mathrm{H} 2 \mathrm{O}, \mathrm{PG}}}{\dot{m}_{\mathrm{steam}, \mathrm{GR}}+\dot{m}_{\mathrm{H} 2 \mathrm{O}, \mathrm{GR}, \text { fuel }}} \\
\eta_{\mathrm{CG}} & =\frac{\dot{V}_{\mathrm{PG}} \times L H V_{\mathrm{PG}}}{\dot{m}_{\mathrm{GR}, \text { fuel }} \times L H V_{\mathrm{GR}, \text { fuel }}} .100 \\
\eta_{\mathrm{CG}, \mathrm{o}} & =\frac{\dot{V}_{\mathrm{PG}} \times L H V_{\mathrm{PG}}}{\dot{m}_{\mathrm{GR}, \text { fuel }} \times L H V_{\mathrm{GR}, \text { fuel }}+\dot{m}_{\mathrm{CR}, \text { fuel }} \times L H V_{\mathrm{CR}, \text { fuel }}-Q_{\mathrm{loss}}} .100
\end{aligned}
$$

\section{Results from gasification experiments}

\subsection{Temperature and pressure profiles}

Beside typical temporal courses of different temperatures (cf. Figure 4) of the DFB gasification pilot plant, temperature and pressure profiles over the height of the fluidized bed reactor system comprise important information for the process control of gasification test runs. Figure 16 shows typical temperature and pressure profiles over the GR and $\mathrm{CR}$ reactor heights of a typical gasification test run as an example. A major advantage of the new reactor design is the high-temperature solids held up in the upper GR caused by constrictions. The product gas quality is influenced in a positive way, because the upstreaming tar-rich product gas from the lower GR passes zones of solids like bed material, ash particles, and unconverted char. The combination of increased temperature with catalytically active solids leads to an increased conversion of formerly unconverted and unwanted product gas components like fly char, higher gaseous hydrocarbons, and tar [24]. The hold up of particles above every single constriction inside the upper GR is visible in the pressure profile (or pressure gradient). Favorable pressure profiles were first investigated in cold flow models. These findings helped in the adjustment of advantageous operational fluid dynamics inside the pilot plant with temperatures up to $1000{ }^{\circ} \mathrm{C}$. Simply, the pressure profiles show where the bed material is (cf. Figure 8), and the circulation of bed material can be derived from them [45].

\subsection{Fuel variation}

This section includes results from various gasification test runs with the $100 \mathrm{~kW}$ pilot plant with 

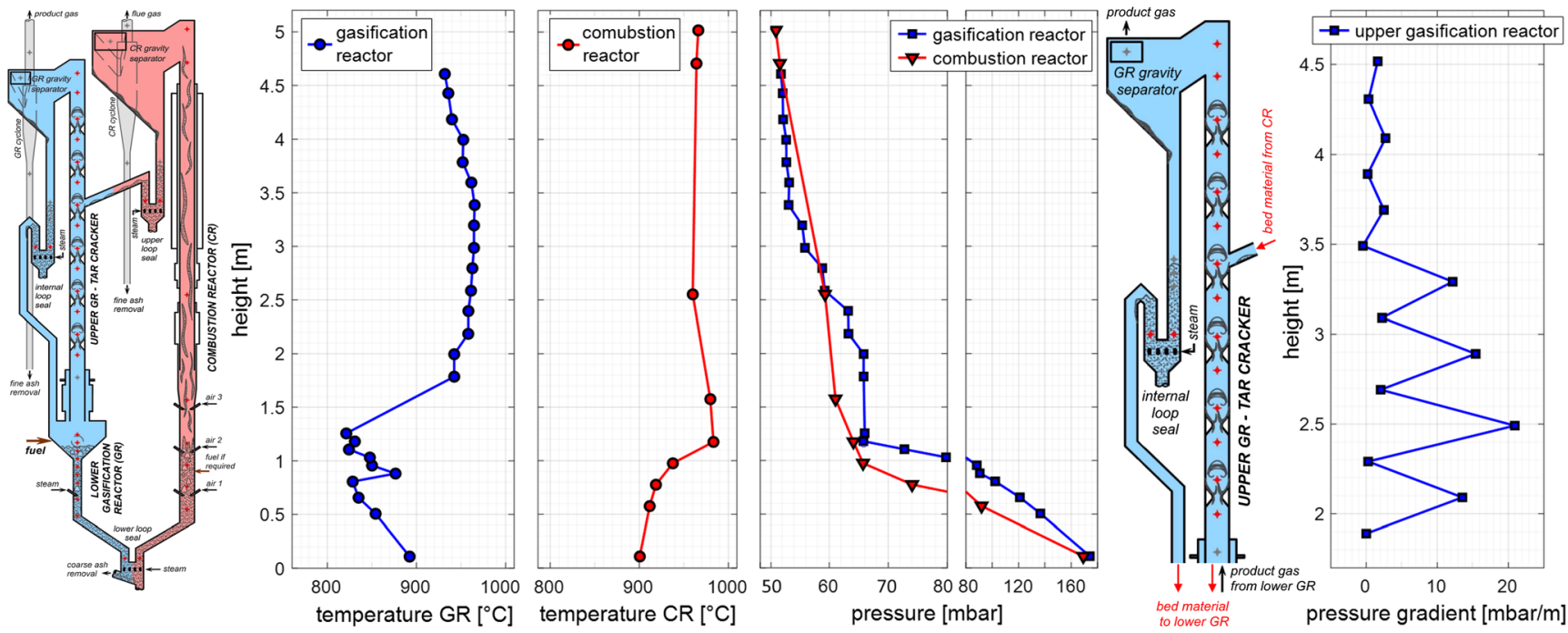

Fig. 16 Temperature and pressure profiles of a gasification test run with the advanced $100 \mathrm{~kW}$ pilot plant

lignocellulosic and residual biogenic fuels, which were gasified during the last 5 years. Table 4 presents the main parameters for the steady-state operation of the DFB steam gasification test runs. A typical experimental duration of approximately a day leads to a number of periods of steady-state operation (at least $30 \mathrm{~min}$ each) for experimental validation. For most of the fuels, problem-free gasification operation was achieved during the one-day trial. Two fuel types faced problems. First, rice husk (RH) pellets led to ash skeletons clogging the fluidized loop seals [65]. Second, during hazelnut shell (HNS) gasification, ash initiated sintering effects of the bed material particles. Both test runs had to be stopped after a steady-state operation phase to evaluate the test runs. All test runs show similar main product gas compositions leaving the GR of the DFB system. However, the tar content of the product gas was changed over a wide range by varying the fuel and bed materials. Figure 17 shows the composition of the thereby generated product gases, and, in Figure 18, the tar concentrations and calculated tar dew points in the product gas are presented. A test run with lignin as a fuel led to the highest presented tar and benzene content in the product gas. Considering the molecular structure of the fuel type lignin (as a cross-linked phenolic polymer) and knowing the specific devolatilization and gasification behavior, the result is comprehensible [58]. The fuel lignin is predestined to produce benzene and polycyclic aromatic hydrocarbons (like naphthalene or anthracene) as tar content. The shown tolerance ranges of the mean values include the measurement inaccuracy, the variance of the measurement values (if several measurement values are present), and the deviation caused by measurement fluctuations or slight value changes during a steady-state phase. Other minor product gas components and fly char or dust contents in the product gas leaving the GR of the DFB reactor system are presented in Table 5. Ammonia $\left(\mathrm{NH}_{3}\right)$ and hydrogen sulfide $\left(\mathrm{H}_{2} \mathrm{~S}\right)$ predominately correlate with the elemental content of nitrogen $(\mathrm{N})$ and sulfur $(\mathrm{S})$ in the fuel (cf. Table 2) $[58,66,67]$. It is interesting to see that the dust content in the product gas is ca. 10 times higher than normal if the product gas cyclone is not working properly (cf. Table 5, 3rd and 5th test runs). Note that Table 1 presents the single GC-MS tar components of the displayed 3rd test run with bark (BA) as fuel and 100\% limestone as the bed material.

Based on the measurements and mass and energy balances with IPSEpro, the calculated operating parameters and performance indicating key figures of the test runs with different fuels are presented in Table 6. The 8 th test run with bark (BA) as fuel and a quartzlimestone mix as a bed material shows interesting results. The product gas power is slightly higher than the fuel input power into the GR, which may be explained by the considerably improved water and fuel conversion rates caused by catalytically active substances like $\mathrm{CaO}$ (from limestone and fuel ash) and comparable high gasification temperatures in the lower GR. Nevertheless, the process conditions are reached because of a significantly increased additional fuel input into the $\mathrm{CR}$ to raise the GR temperatures (cf. Table 4). Thus, the calculated overall cold gas efficiency was in a similar range like in other test runs. In general, it was possible to reach high overall cold gas efficiencies between 67 and $73 \%$ with the advanced DFB gasifier design. Literature shows that these calculated overall cold gas efficiencies of the $100 \mathrm{~kW}$ plant are in the range of practical cold gas efficiencies of industrial-sized steamblown DFB gasifiers $[4,8,10,68]$. Therefore, the 


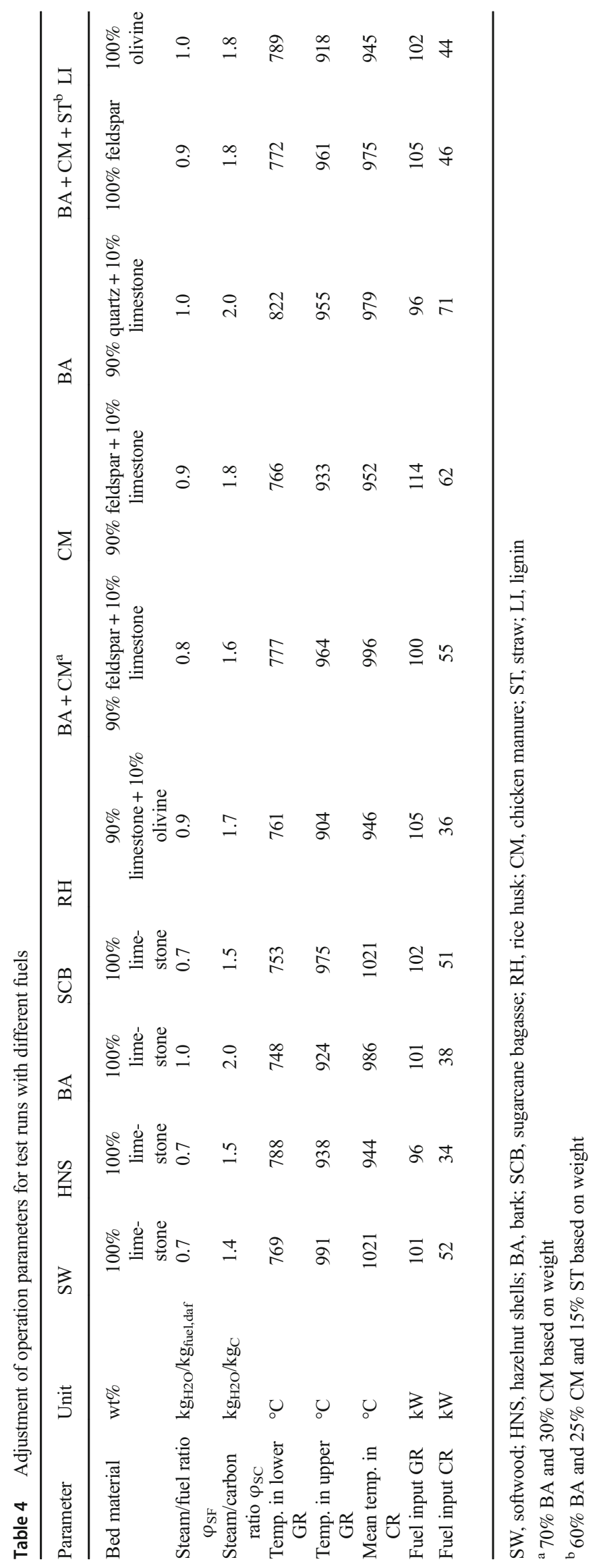




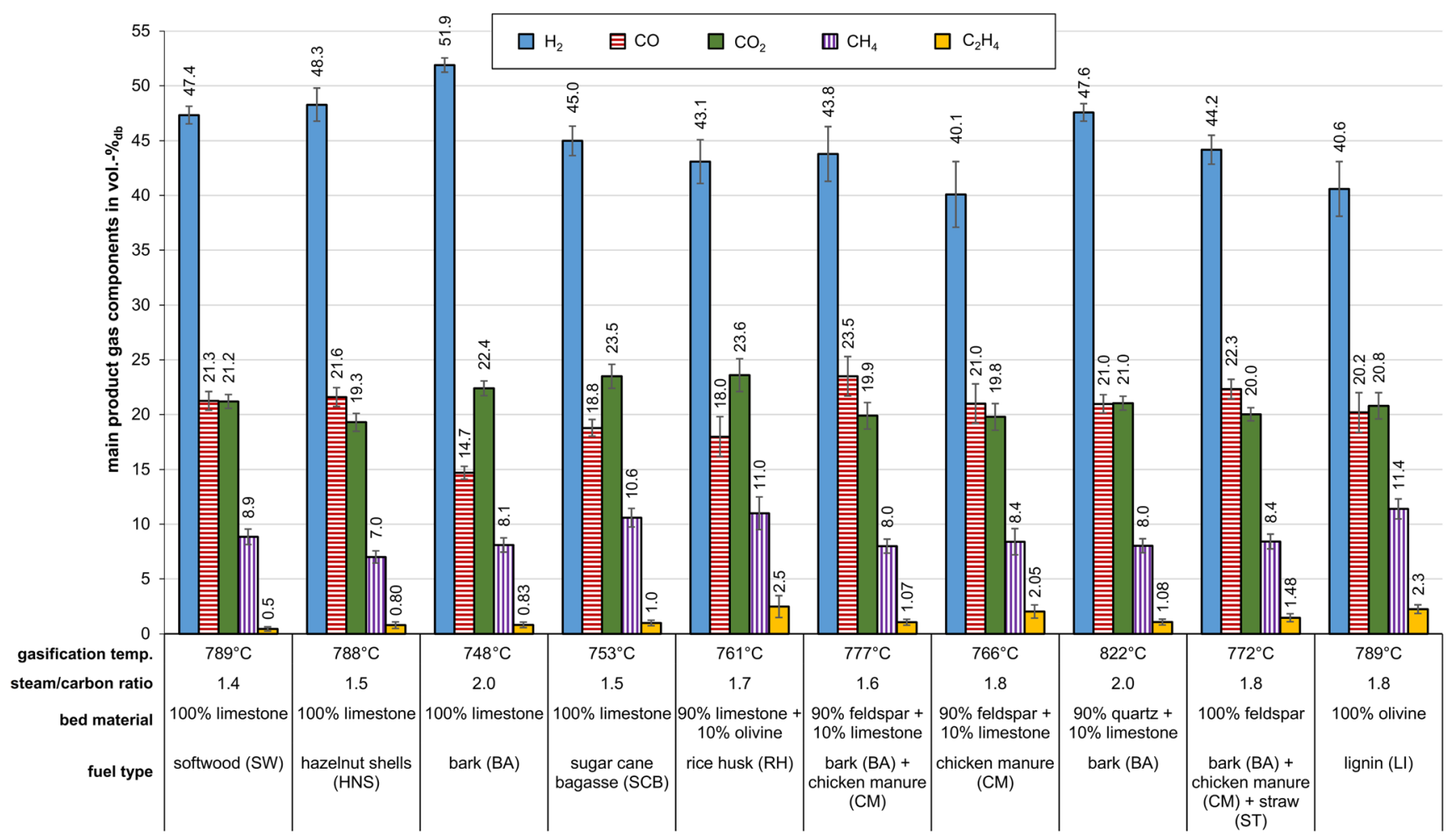

Fig. 17 Product gas composition for different lignocellulosic and residual biogenic fuels

presented calculation method (cf. Eq. (9)) is representative of the potential of future industrial plants. Additional results of the gasification of different fuel types like lignite (brown coal) or plastic waste materials and correlations between fuel composition and product gas quality for the advanced reactor design can be found in literature [46, 69]. For previous generation of the $100 \mathrm{~kW}$ gasification test plant at TU Wien (classic

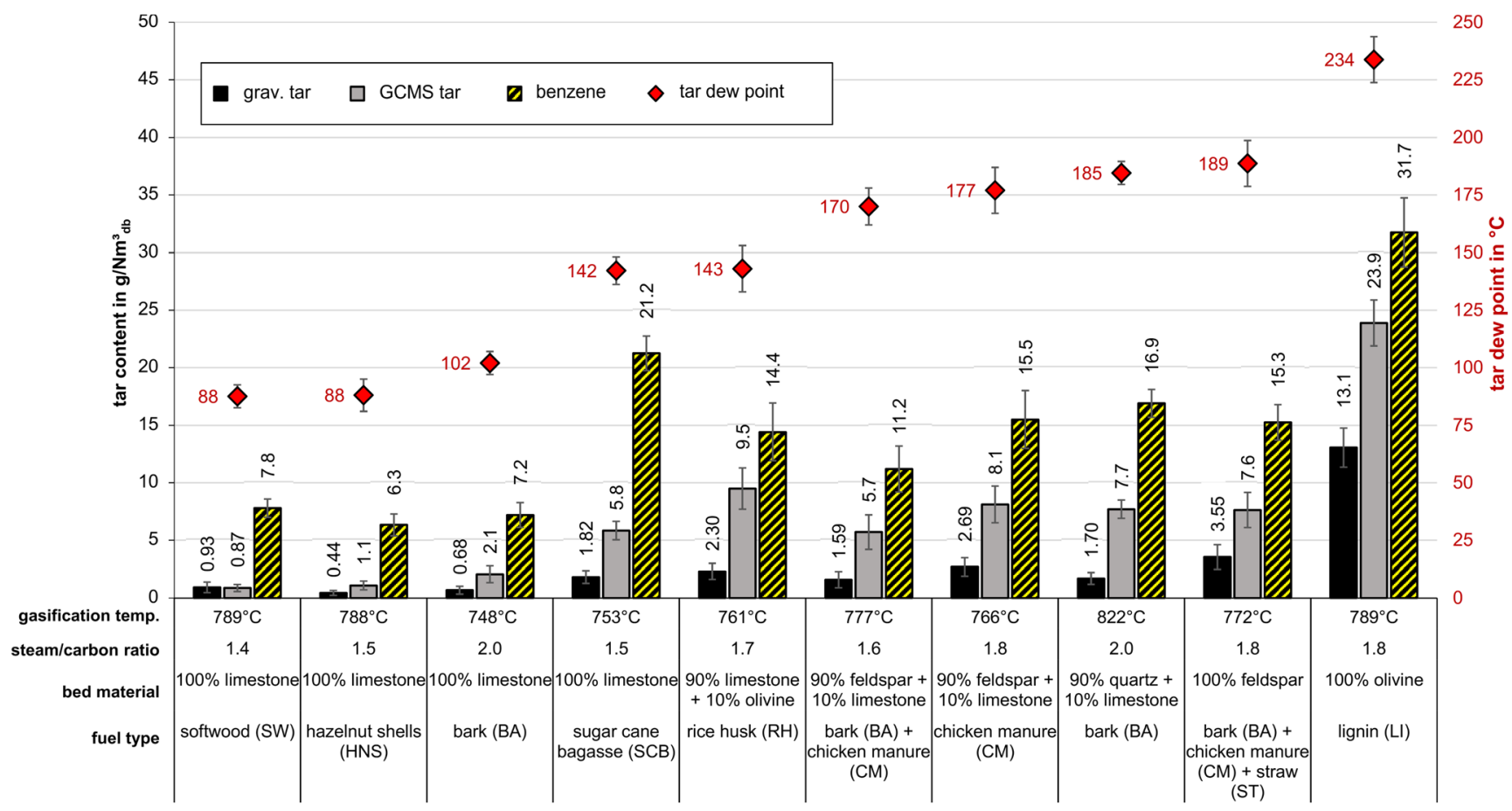

Fig. 18 Tar content and tar dew point for different lignocellulosic and residual biogenic fuels 
Table 5 Water content and minor product gas components for different lignocellulosic and residual biogenic fuels

\begin{tabular}{llllllllllll}
\hline Parameter & Unit & SW & HNS & BA & SCB & RH & BA+CM & CM & BA & BA+CM+ST & LI \\
\hline Water content & vol\% & $25-29$ & $23-28$ & $37-42$ & $35-36$ & $43-46$ & $31-32$ & $31-35$ & $29-36$ & $39-41$ & $32-42$ \\
Fly char & $\mathrm{g} / \mathrm{Nm}_{\mathrm{db}}^{3}$ & $1-3$ & $1-2$ & $7-10^{*}$ & $4-9$ & $5-7^{*}$ & $1.5-3$ & $0.5-1$ & $2-4$ & $1-1.5$ & $0.5-2$ \\
Dust & $\mathrm{g} / \mathrm{Nm}_{\mathrm{db}}^{3}$ & $1-4$ & $1-3$ & $15-22^{*}$ & $6-8$ & $55-70^{*}$ & $3-4$ & $4-7$ & $1-3$ & $0.5-2$ & $0.5-1$ \\
$\mathrm{NH}_{3}$ & vol ppm & n.m. & n.m. & $3300^{* *}$ & n.m. & 7600 & 23,800 & 73,200 & n.m. & 23,900 & n.m. \\
$\mathrm{H}_{2} \mathrm{~S}$ & vol ppm & $17-23$ & n.m. & $190-275$ & n.m. & 460 & $360-480$ & $340-390$ & n.m. & 140 & n.m. \\
$\mathrm{COS}$ & vol ppm & $0.1-0.7$ & n.m. & $0.3-0.7$ & n.m. & n.m. & $13-16$ & $25-61$ & n.m. & n.m. \\
$\mathrm{HCl}$ & vol ppm & n.m. & n.m. & $0.6^{* *}$ & n.m. & n.m. & n.m. & n.m. & n.m. & 14 & n.m. \\
$\mathrm{HCN}$ & vol ppm & n.m. & n.m. & n.m. & n.m. & n.m. & n.m. & n.m. & n.m. & 400 & n.m. \\
\hline
\end{tabular}

SW, softwood; HNS, hazelnut shells; BA, bark; SCB, sugarcane bagasse; RH, rice husk; CM, chicken manure; ST, straw; LI, lignin; n.m., not measured

*High content because the cyclone downcomer clogged

*** Value from a similar test run with bark

a $70 \%$ BA and $30 \% \mathrm{CM}$ based on weight

${ }^{\mathrm{b}} 60 \% \mathrm{BA}$ and $25 \% \mathrm{CM}$ and $15 \%$ ST based on weight

reactor design, cf. Figure 1), results with various fuel types can be found in the literature $[7-9,13,15,56$, 70].

\subsection{Bed material variation}

The state-of-the-art bed material typically used in industrial-sized DFB plants is olivine [71, 72]. The advantage of olivine is its catalytic activity due to the formation of calcium-rich layers on the surface of the particles during long-term operation. These layers are formed due to the interaction of bed material particles with ash from the biomass and improve the catalytic activity, which is especially important in tar-destruction processes $[60,61,73]$. Since olivine is relatively expensive, and its availability is regionally limited, the focus of many investigations is on finding alternative bed materials that are inexpensive and available worldwide. For this purpose, quartz, limestone, and feldspar were selected as alternative materials to the conventionally used olivine. Test runs with different bed materials were already conducted in the classic design of the DFB gasification [7, 74]. However, in the advanced design, these investigations were carried out for the first time and with different mixture ratios. In Figure 19, the courses of the main product gas components and the tar content are presented dependent on gasification with softwood from $100 \mathrm{wt} \%$ quartz, $100 \mathrm{wt} \%$ olivine, and $100 \mathrm{wt} \%$ feldspar to $100 \mathrm{wt} \%$ limestone used as bed materials. Typical gasification temperatures $\left(770-840{ }^{\circ} \mathrm{C}\right)$ and steam-to-carbon ratios (1.4-1.9) were adjusted, and clear general trends are obvious. By increasing the limestone content, $\mathrm{H}_{2}$ increases to a maximum, and the tar content in the product gas is significantly reduced during the

Table 6 Calculated parameters and performance indicating key figures for test runs with different fuels

\begin{tabular}{|c|c|c|c|c|c|c|c|c|c|c|c|}
\hline Parameter & Unit & SW & HNS & $\mathrm{BA}$ & SCB & $\mathrm{RH}$ & $\mathrm{BA}+\mathrm{CM}^{\mathrm{a}}$ & $\mathrm{CM}$ & BA & $\mathrm{BA}+\mathrm{CM}+\mathrm{ST}^{\mathrm{b}}$ & LI \\
\hline PGY & $\mathrm{Nm}_{\mathrm{db}}^{3} / \mathrm{kg}_{\mathrm{daf}}$ & 1.4 & 1.5 & 1.4 & 1.2 & 1.2 & 1.4 & 1.5 & 1.8 & 1.3 & 1.6 \\
\hline Product gas volume flow & $\mathrm{Nm}_{\mathrm{db}}^{3} / \mathrm{h}$ & 34.4 & 27.4 & 27 & 24.9 & 23.8 & 28.2 & 31.4 & 32.6 & 26.1 & 27.2 \\
\hline$L H V_{\mathrm{PG}}{ }^{*}$ & $\mathrm{MJ} / \mathrm{Nm}_{\mathrm{db}}^{3}$ & 11.3 & 11.3 & 11 & 11.7 & 12.5 & 12 & 12 & 11.4 & 11.9 & 12.7 \\
\hline Product gas power ${ }^{*}$ & $\mathrm{~kW}$ & 88 & 86 & 83 & 81 & 83 & 91 & 107 & 103 & 86 & 96 \\
\hline$X_{\mathrm{H} 2 \mathrm{O}}$ & $\mathrm{kg}_{\mathrm{H} 2 \mathrm{O}} / \mathrm{kg}_{\mathrm{H} 2 \mathrm{O}}$ & 0.36 & 0.36 & 0.35 & 0.29 & 0.18 & 0.34 & 0.38 & 0.42 & 0.24 & 0.41 \\
\hline$\eta_{\mathrm{CG}}$ & $\%$ & 88 & 90 & 82 & 79 & 79 & 91 & 94 & 108 & 82 & 94 \\
\hline$\eta_{\mathrm{CG}, \mathrm{O}}$ & $\%$ & 73 & 72 & 67 & 67 & 71 & 72 & 71 & 73 & 70 & 73 \\
\hline
\end{tabular}

SW, softwood; HNS, hazelnut shells; BA, bark; SCB, sugarcane bagasse; RH, rice husk; CM, chicken manure; ST, straw; LI, lignin

* Dry basis and char- and tar-free

a $70 \% \mathrm{BA}$ and $30 \% \mathrm{CM}$ based on weight

${ }^{\mathrm{b}} 60 \% \mathrm{BA}$ and $25 \% \mathrm{CM}$ and $15 \%$ ST based on weight 
Fig. 19 Course of main product gas components (left) and tar content (right) for different bed material mixtures [75]
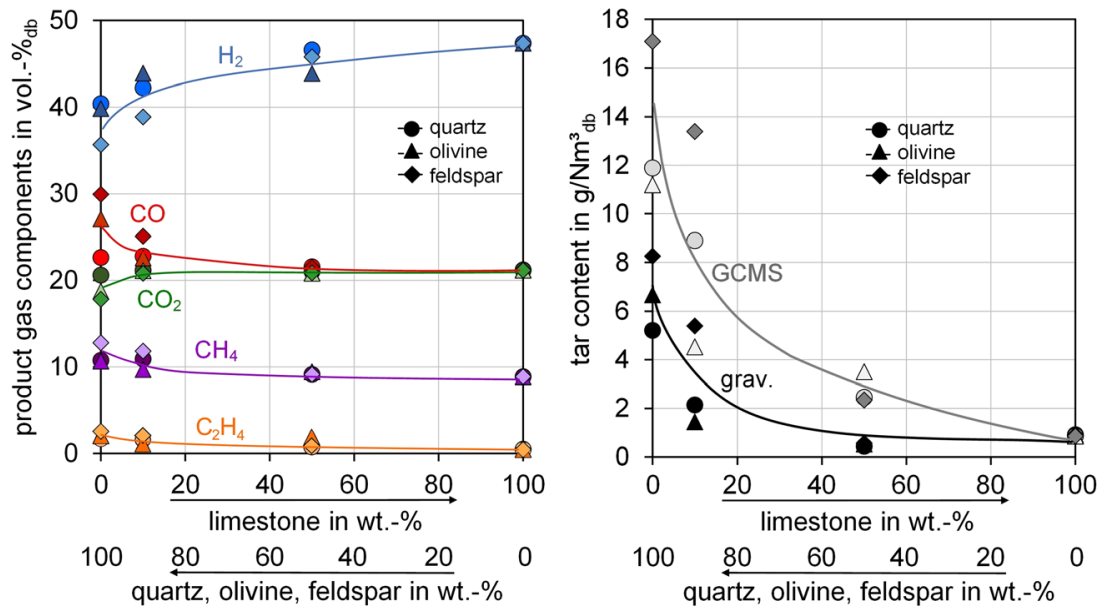
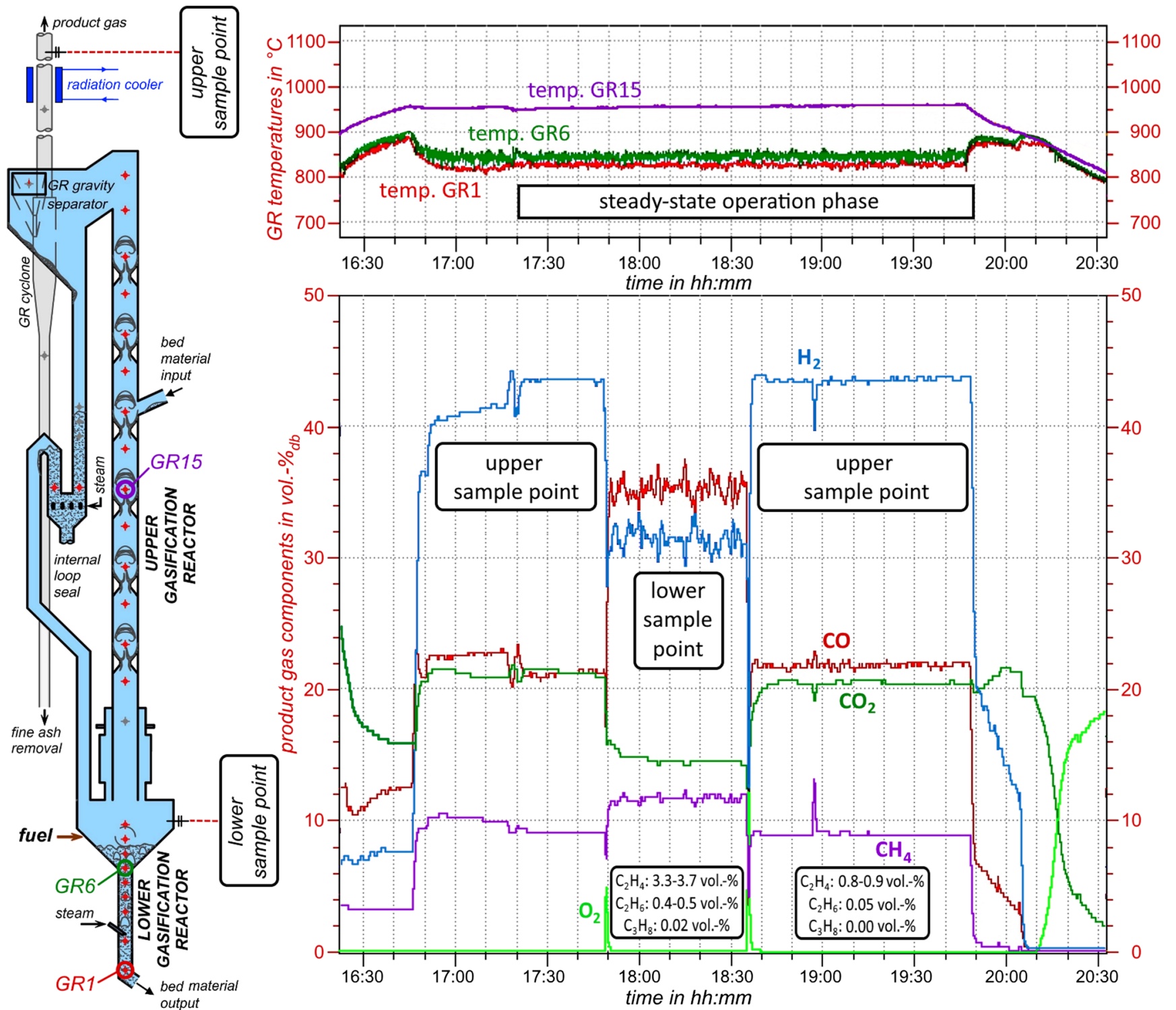

Fig. 20 Course of temperatures over time in the GR and product gas composition during gasification of softwood at $848^{\circ} \mathrm{C}$ and a bed material mixture of $90 \mathrm{wt} \%$ olivine and $10 \mathrm{wt} \%$ limestone 


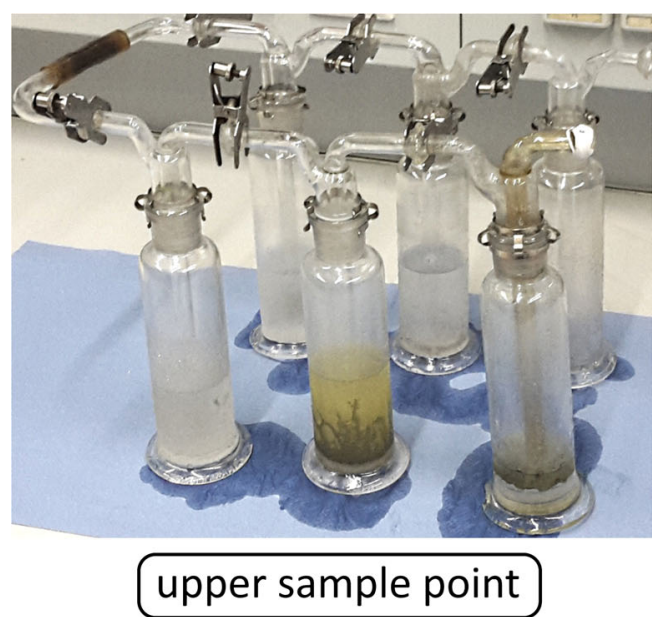

GCMS tar: $4.53 \mathrm{~g} / \mathrm{Nm}_{\mathrm{db}}^{3}$ grav. tar: $1.46 \mathrm{~g} / \mathrm{Nm}_{\mathrm{db}}^{3}$

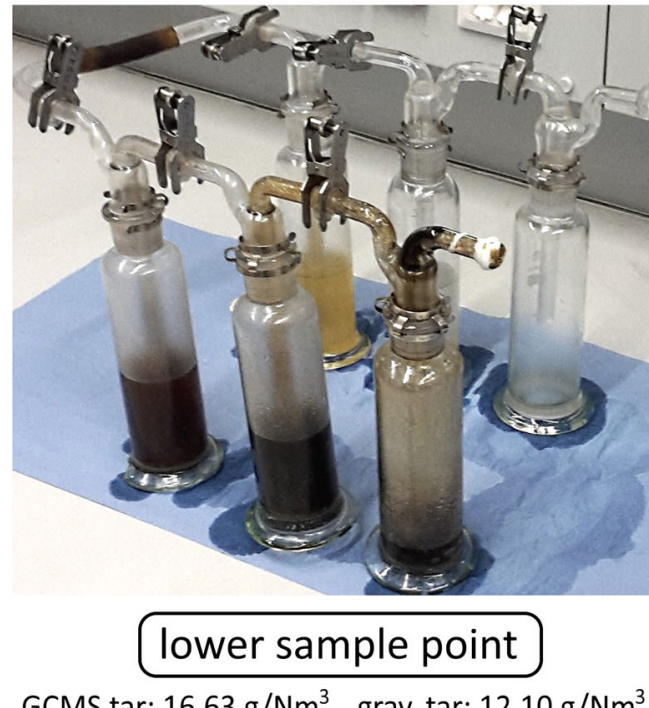

GCMS tar: $16.63 \mathrm{~g} / \mathrm{Nm}_{\mathrm{db}}^{3}$ grav. tar: $12.10 \mathrm{~g} / \mathrm{Nm}_{\mathrm{db}}^{3}$

Fig. 21 Pictures of impinge bottles after tar sampling procedure before and after the upper GR, steam gasification of softwood at $848^{\circ} \mathrm{C}$, bed material mixture of $90 \mathrm{wt} \%$ olivine, and $10 \mathrm{wt} \%$ limestone

test run with $100 \mathrm{wt} \%$ limestone. This can be explained by the catalytic activity of $\mathrm{CaO}$, which is formed at high temperatures out of limestone. Previous work by Mauerhofer et al. [75] presents extensive results including a detailed interpretation and discussion. Beside steam $\left(\mathrm{H}_{2} \mathrm{O}\right)$ as a gasification agent, Jeremiáš et al. [76] show similar results for $\mathrm{CO}_{2}$ as gasification agent.

\subsection{Product gas quality before and after the upper gasification reactor}

The goal of Figure 20 is to show the impact of the upper GR of the advanced pilot plant at TU Wien. Softwood as fuel was gasified at a temperature of approximately $848{ }^{\circ} \mathrm{C}$. During the steady-state operation phase, the online measurement of the main product gas components was switched between the upper sample point and the lower sample point of the DFB plant. It is obvious that the carbon monoxide (CO)-rich gaseous product gas in the lower part of the GR is transformed into a hydrogen $\left(\mathrm{H}_{2}\right)$-rich gas with a lower amount of higher gaseous hydrocarbon contents. Thus, the upper GR supports the water gas shift reaction $\left(\mathrm{H}_{2}, \mathrm{CO}\right)$, thermal cracking, and steam-reforming of tar, $\mathrm{C}_{2} \mathrm{H}_{4}$, and $\mathrm{C}_{2} \mathrm{H}_{6}$. Additionally, Figure 21 clearly shows the in situ reduction of the tar content of the generated product gas inside the GR of the fluidized bed system. In 2011, Schmid et al. [24, 77] expected exactly these effects during the conceptual design of the advanced fluidized bed system.

Table 7 presents the tar measurement report from the sampling procedure shown in Figure 21 during the gasification test run shown in Figure 20. In steady-state operation, two sample procedures at the upper and lower sample points were carried out at the same time for $8 \mathrm{~min}$. Toluene was used as a solvent. It is worthy of note that the product gas temperature at the gas sample points is higher than $400{ }^{\circ} \mathrm{C}$ to prevent partial condensation of tar components inside the product gas pipes before the sampling equipment. Therefore, a special radiation cooler with controllable (limited) heat flux was installed before the upper sample point. In addition to the visible tar reduction of the process shown in Figure 21, the measurement results presented in Table 7 show that most of the single GC-MS tar components were fully converted or significantly reduced during the flow through the upper GR. At this point, hazardous tar components like phenols were not present anymore in the product gas stream after the upper GR. Only for naphthalene, anthracene, fluoranthene, and pyrene, it seemed that a more catalytic active bed material (like $100 \%$ limestone/CaO) would be needed to crack or reform such tar components to very low concentrations (cf. Table 1). Nevertheless, the effective reduction of the gravimetric tar, representing the problematic heavy polycyclic aromatic hydrocarbons, is a highlight. Heavy polycyclic aromatic hydrocarbon contents (grav. tar) are the main reason for fouling and clogging effects inside product gas pipes and apparatuses of gasifiers. Reduction of such tar components is very important if alternative fuel types are gasified, leading to the production of higher tar loads. Thus, the advanced GR design ensures good preconditions for the utilization of alternative fuel types, such as waste materials and residues.

To sum up previous findings concerning the variations experienced in changing from the use of olivine as bed material particles toward limestone, Figure 22 shows the change of product gas before and after the upper GR for different mixture ratios of the bed 
Table 7 Comparison of single GC-MS tar components before and after the upper GR

General information

\begin{tabular}{|c|c|c|c|}
\hline Solvent & - & Toluene & Toluene \\
\hline Measurement point & - & Upper sample point (after upper GR) & Lower sample point (before upper GR) \\
\hline Gasified fuel & - & Softwood (SW) & Softwood (SW) \\
\hline Bed material & - & $90 \%$ olivine, $10 \%$ limestone & $90 \%$ olivine, $10 \%$ limestone \\
\hline Gasification temperature & ${ }^{\circ} \mathrm{C}$ & $\approx 848$ & $\approx 848$ \\
\hline Water content & $\%$ & 38 & 31 \\
\hline Gravimetric tar & $\mathrm{g} / \mathrm{Nm}_{\mathrm{db}}^{3}$ & 1.46 & 12.10 \\
\hline Sum GC-MS tar & $\mathrm{g} / \mathrm{Nm}_{\mathrm{db}}^{3}$ & 4.53 & 16.63 \\
\hline \multicolumn{4}{|c|}{ Single GC-MS tar components } \\
\hline Phenylacetylene & $\mathrm{mg} / \mathrm{Nm}_{\mathrm{db}}^{3}$ & 0 & 185 \\
\hline Styrene & $\mathrm{mg} / \mathrm{Nm}_{\mathrm{db}}^{3}$ & 73 & 1600 \\
\hline Mesitylene & $\mathrm{mg} / \mathrm{Nm}_{\mathrm{db}}^{3}$ & 0 & 17 \\
\hline Phenol & $\mathrm{mg} / \mathrm{Nm}_{\mathrm{db}}^{3}$ & 0 & 2745 \\
\hline Benzofuran & $\mathrm{mg} / \mathrm{Nm}_{\mathrm{db}}^{3}$ & 0 & 479 \\
\hline 1H-Indene & $\mathrm{mg} / \mathrm{Nm}_{\mathrm{db}}^{3}$ & 113 & 2551 \\
\hline 2-Methylphenol & $\mathrm{mg} / \mathrm{Nm}_{\mathrm{db}}^{3}$ & 0 & 301 \\
\hline 4-Methylphenol & $\mathrm{mg} / \mathrm{Nm}_{\mathrm{db}}^{3}$ & 0 & 797 \\
\hline 2-Methylbenzofuran & $\mathrm{mg} / \mathrm{Nm}_{\mathrm{db}}^{3}$ & 0 & 67 \\
\hline 2,6-Dimethylphenol & $\mathrm{mg} / \mathrm{Nm}_{\mathrm{db}}^{3}$ & 0 & 0 \\
\hline 2,5- and 2,4-Dimethylphenol & $\mathrm{mg} / \mathrm{Nm}_{\mathrm{db}}^{3}$ & 0 & 91 \\
\hline 3,5-Dimethylphenol & $\mathrm{mg} / \mathrm{Nm}_{\mathrm{db}}^{3}$ & 0 & 81 \\
\hline 2,3-Dimethylphenol & $\mathrm{mg} / \mathrm{Nm}_{\mathrm{db}}^{3}$ & 0 & 63 \\
\hline 3,4-Dimethylphenol & $\mathrm{mg} / \mathrm{Nm}_{\mathrm{db}}^{3}$ & 0 & 0 \\
\hline 2-Methoxy-4-methylphenol & $\mathrm{mg} / \mathrm{Nm}_{\mathrm{db}}^{3}$ & 0 & 0 \\
\hline Naphthalene & $\mathrm{mg} / \mathrm{Nm}_{\mathrm{db}}^{3}$ & 2438 & 3106 \\
\hline 1-Benzothiophene & $\mathrm{mg} / \mathrm{Nm}_{\mathrm{db}}^{3}$ & 0 & 0 \\
\hline Quinoline & $\mathrm{mg} / \mathrm{Nm}_{\mathrm{db}}^{3}$ & 0 & 0 \\
\hline 2-Methylnaphthalene & $\mathrm{mg} / \mathrm{Nm}_{\mathrm{db}}^{3}$ & 0 & 567 \\
\hline Isoquinoline & $\mathrm{mg} / \mathrm{Nm}_{\mathrm{db}}^{3}$ & 0 & 0 \\
\hline 1-Methylnaphthalene & $\mathrm{mg} / \mathrm{Nm}_{\mathrm{db}}^{3}$ & 0 & 381 \\
\hline 1-Vinylnaphthalene & $\mathrm{mg} / \mathrm{Nm}_{\mathrm{db}}^{3}$ & n.a. & n.a. \\
\hline 2-Vinylnaphthalene & $\mathrm{mg} / \mathrm{Nm}_{\mathrm{db}}^{3}$ & n.a. & n.a. \\
\hline 1-Indanone & $\mathrm{mg} / \mathrm{Nm}_{\mathrm{db}}^{3}$ & 0 & 31 \\
\hline Eugenol & $\mathrm{mg} / \mathrm{Nm}_{\mathrm{db}}^{3}$ & 0 & 0 \\
\hline Indole & $\mathrm{mg} / \mathrm{Nm}_{\mathrm{db}}^{3}$ & 0 & 58 \\
\hline Biphenyl & $\mathrm{mg} / \mathrm{Nm}_{\mathrm{db}}^{3}$ & 55 & 212 \\
\hline Isoeugenol & $\mathrm{mg} / \mathrm{Nm}_{\mathrm{db}}^{3}$ & 0 & 0 \\
\hline Acenaphthylene & $\mathrm{mg} / \mathrm{Nm}_{\mathrm{db}}^{3}$ & 664 & 1301 \\
\hline Acenaphthene & $\mathrm{mg} / \mathrm{Nm}_{\mathrm{db}}^{3}$ & 16 & 64 \\
\hline Dibenzofuran & $\mathrm{mg} / \mathrm{Nm}_{\mathrm{db}}^{3}$ & 27 & 190 \\
\hline Fluorene & $\mathrm{mg} / \mathrm{Nm}_{\mathrm{db}}^{3}$ & 27 & 367 \\
\hline Dibenzothiophene & $\mathrm{mg} / \mathrm{Nm}_{\mathrm{db}}^{3}$ & 0 & 0 \\
\hline 2-Methylpyridine & $\mathrm{mg} / \mathrm{Nm}_{\mathrm{db}}^{3}$ & n.a. & n.a. \\
\hline 3- and 4-Methylpyridine & $\mathrm{mg} / \mathrm{Nm}_{\mathrm{db}}^{3}$ & n.a. & n.a. \\
\hline Anthracene & $\mathrm{mg} / \mathrm{Nm}_{\mathrm{db}}^{3}$ & 499 & 482 \\
\hline Phenanthrene & $\mathrm{mg} / \mathrm{Nm}_{\mathrm{db}}^{3}$ & 103 & 171 \\
\hline Carbazole & $\mathrm{mg} / \mathrm{Nm}_{\mathrm{db}}^{3}$ & 0 & 0 \\
\hline 4,5-Methylphenanthrene & $\mathrm{mg} / \mathrm{Nm}_{\mathrm{db}}^{3}$ & 23 & 130 \\
\hline
\end{tabular}


Table 7 (continued)

General information

\begin{tabular}{|c|c|c|c|}
\hline Solvent & - & Toluene & Toluene \\
\hline 9-Methylanthracene & $\mathrm{mg} / \mathrm{Nm}_{\mathrm{db}}^{3}$ & 0 & 0 \\
\hline Fluoranthene & $\mathrm{mg} / \mathrm{Nm}_{\mathrm{db}}^{3}$ & 219 & 187 \\
\hline Pyrene & $\mathrm{mg} / \mathrm{Nm}_{\mathrm{db}}^{3}$ & 177 & 171 \\
\hline Benzo[a]anthracene & $\mathrm{mg} / \mathrm{Nm}_{\mathrm{db}}^{3}$ & 40 & 82 \\
\hline Chrysene & $\mathrm{mg} / \mathrm{Nm}_{\mathrm{db}}^{3}$ & 57 & 71 \\
\hline Benzo[b]fluoranthene & $\mathrm{mg} / \mathrm{Nm}_{\mathrm{db}}^{3}$ & 0 & 37 \\
\hline Benzo[k]fluoranthene & $\mathrm{mg} / \mathrm{Nm}_{\mathrm{db}}^{3}$ & 0 & 0 \\
\hline Benzo[a]pyrene & $\mathrm{mg} / \mathrm{Nm}_{\mathrm{db}}^{3}$ & 0 & 45 \\
\hline Benzo[e]pyrene & $\mathrm{mg} / \mathrm{Nm}_{\mathrm{db}}^{3}$ & n.a. & n.a. \\
\hline Benzo[g,h,i]perylene & $\mathrm{mg} / \mathrm{Nm}_{\mathrm{db}}^{3}$ & 0 & 0 \\
\hline Dibenz[a,h]anthracene & $\mathrm{mg} / \mathrm{Nm}_{\mathrm{db}}^{3}$ & 0 & 0 \\
\hline Indeno[1,2,3-cd]pyrene & $\mathrm{mg} / \mathrm{Nm}_{\mathrm{db}}^{3}$ & 0 & 0 \\
\hline Perylene & $\mathrm{mg} / \mathrm{Nm}_{\mathrm{db}}^{3}$ & n.a. & n.a. \\
\hline \multirow[t]{2}{*}{ Coronene } & $\mathrm{mg} / \mathrm{Nm}_{\mathrm{db}}^{3}$ & n.a. & n.a. \\
\hline & & Single BTEX components & \\
\hline Benzene & $\mathrm{mg} / \mathrm{Nm}_{\mathrm{db}}^{3}$ & n.a. & n.a. \\
\hline Toluene & $\mathrm{mg} / \mathrm{Nm}_{\mathrm{db}}^{3}$ & n.d. & n.d. \\
\hline Ethylbenzene & $\mathrm{mg} / \mathrm{Nm}_{\mathrm{db}}^{3}$ & n.a. & n.a. \\
\hline $\mathrm{m}$ - and $\mathrm{p}$-Xylene & $\mathrm{mg} / \mathrm{Nm}_{\mathrm{db}}^{3}$ & n.a. & n.a. \\
\hline o-Xylene & $\mathrm{mg} / \mathrm{Nm}_{\mathrm{db}}^{3}$ & n.a. & n.a. \\
\hline
\end{tabular}

n.a., not analyzed; n.d., not determinable

material. In the test runs, pure olivine was replaced by 10,50 , and $100 \mathrm{wt} \%$ of limestone. The product gas composition and its tar concentration were greatly influenced by the choice of bed material. The greatest influence of the type of bed material (100\% olivine vs. $100 \%$ limestone) on the main product gas composition was present directly in the devolatilization and gasification zone of the lower GR. With a look on the results from the upper sample point after the upper GR, the use of limestone as bed material catalyzed the product gas toward water-gas equilibrium composition and tar cracking or steam-reforming reactions were enhanced. A combination of the advanced reactor design and a catalytic active bed material mixture (with limestone contents of min. $10 \mathrm{wt} \%$ ) seems to be very beneficial in ensuring an efficient gasification process.

\subsection{Change of product gas and tar content along gasification reactor height}

As presented in the previous part of this publication, measurements of the main product gas components and tar contents before and after the upper GR have been in many test campaigns. However, the possibility of measuring the product gas along the full height of the countercurrent column of the GR presents a novel method for gaining a detailed insight into the effects of the countercurrent column. Figure 23 presents the course of gaseous products and tar contents along the GR height for the gasification of softwood with a mixture of olivine and limestone $(50 / 50 \mathrm{wt} \%)$ as bed material. Mauerhofer et al. present a detailed explanation of the process condition, sample and measurement procedures, and comparison with additional test runs [48].

Figure 23 shows that higher hydrocarbons like $\mathrm{C}_{2} \mathrm{H}_{4}$ and $\mathrm{C}_{2} \mathrm{H}_{6}$ showed a declining trend along the height of the GR. This could be explained by a combination of thermal cracking and steam-reforming reactions, which converted hydrocarbons into $\mathrm{CO}$ and $\mathrm{H}_{2}$. Furthermore, the enhancement of the water gas shift reaction along the reactor height affected the increasing formation of $\mathrm{H}_{2}$ and $\mathrm{CO}$ decreased at the same time. On the one hand, these effects were supported by the catalytic activity of limestone, which favored the ongoing chemical reactions. On the other hand, the design of the countercurrent upper GR improved the interaction of downwardflowing hot bed material particles with upward-flowing product gas. Thus, the optimized thermal and chemical driving forces increased the conversion efficiencies. Nevertheless, $\mathrm{CH}_{4}$ seems not to convert with the same 

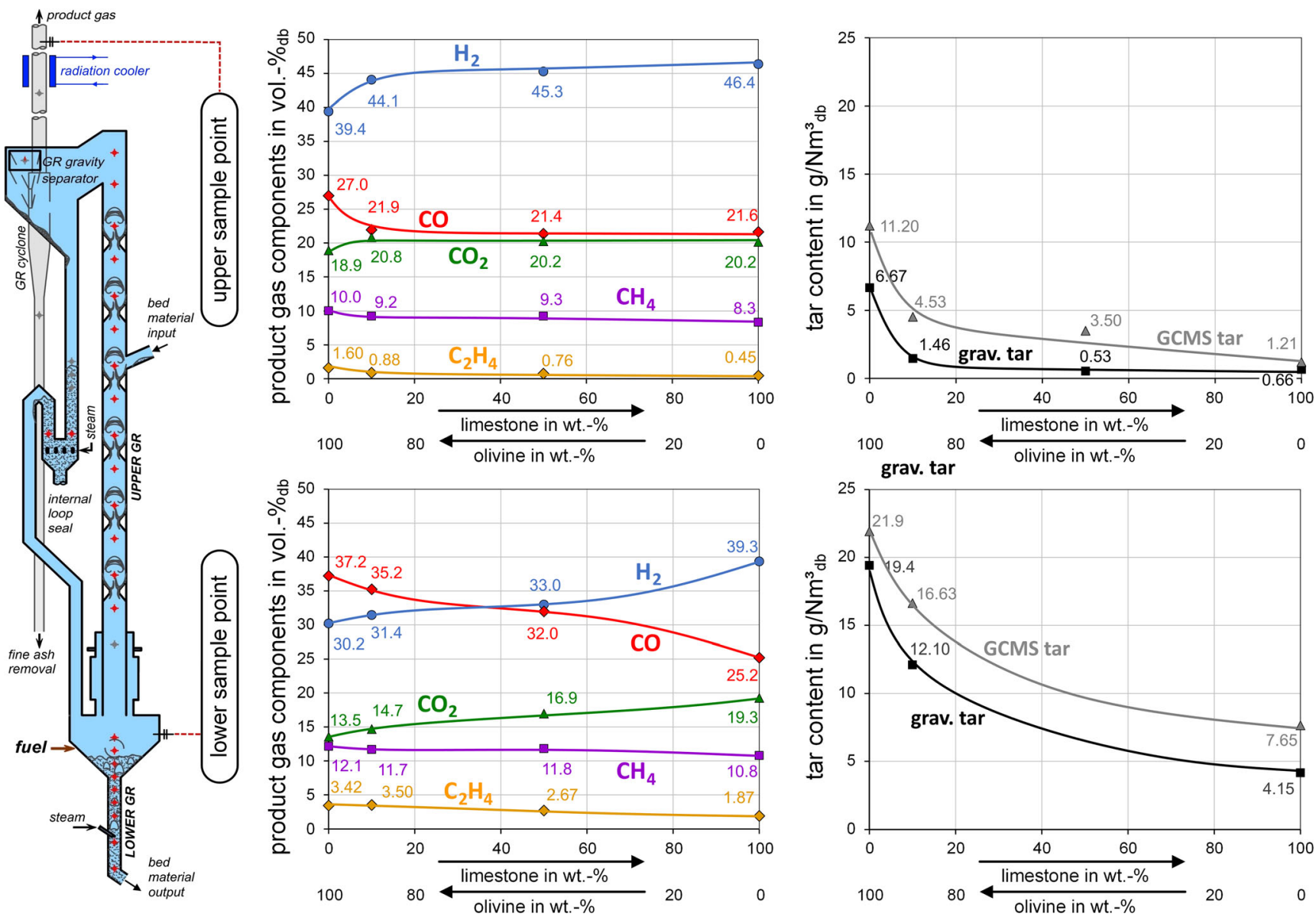

Fig. 22 Comparison of product gas composition (left) and tar content (right) between upper and lower sample points with bed material variation from pure olivine to pure limestone

relatively high rate than other higher hydrocarbons. It is explained by the very stable molecular structure of $\mathrm{CH}_{4}$. Higher temperatures and the use of another type of bed material as a catalyst can reform $\mathrm{CH}_{4}$ in steam-blown fluidized beds [78]. In addition to the product gas measurement along the height, tar was measured along the countercurrent part of the upper GR as well. Figure 23 also presents the course of GC-MS tar and gravimetric tar. It is evident that the content of tar changes along the GR height significantly. This could be attributed to the improved thermal and catalytic destruction of tar components, especially for higher aromatic tar components. The catalytic activity of $\mathrm{CaO}$ (from the $50 \mathrm{wt} \%$ limestone admixture), as well as the increased gas-solid interaction along the column, clearly enhanced tar reduction. The $\mathrm{C}_{2} \mathrm{H}_{4}$ and GC-MS tar content follow a similar correlation like that presented in Figure 15. Additional figures of the presented test run with courses of specific single tar components and classified tar groups according to their temperature of formation were proposed by Milne and Evans [52] and can be found in a publication of Mauerhofer et al. [48].

\subsection{Influence of $\mathrm{H}_{2} \mathrm{O}$ and $\mathrm{CO}_{2}$ as gasification agents}

In general, the gasification agent has a huge impact on the product gas composition as well as on the reactions of the process and operation of the plant. Typical gasification agents are air, steam $\left(\mathrm{H}_{2} \mathrm{O}\right)$, oxygen $\left(\mathrm{O}_{2}\right)$, and carbon dioxide $\left(\mathrm{CO}_{2}\right)$ or mixtures of these. Regarding the situation at TU Wien, steam has been used for the $100 \mathrm{~kW}$ DFB pilot plant as a state-of-the-art gasification agent for many years. Since 2018, $\mathrm{CO}_{2}$ has also been used as a gasification agent in the new pilot plant. The installations of additional volume flow measurements, mixing valves, and piping equipment enable a stepless mixture of steam and $\mathrm{CO}_{2}$ as fluidization and gasification agent. Beside the GR itself, also the loop seals of the advanced reactor system are equipped with a $\mathrm{CO}_{2}$ fluidization input. Thus, the test runs with $100 \% \mathrm{CO}_{2}$ input as gasification agent are possible. A test campaign involving the use of softwood as fuel and olivine as bed material was conducted at temperatures around $820{ }^{\circ} \mathrm{C}$. For the test campaign, the pilot plant was operated with steam at the beginning of the stationary phase. Subsequently, the $\mathrm{CO}_{2}$ input was increased and the steam input decreased in $\mathrm{CO}_{2} /$ steam ratios of $0 / 100,32 / 68$, 
Fig. 23 Product gas composition and tar contents along the reactor height - gasification of softwood with a mixture of olivine and limestone $(50 / 50 \mathrm{wt} \%)$ as bed material

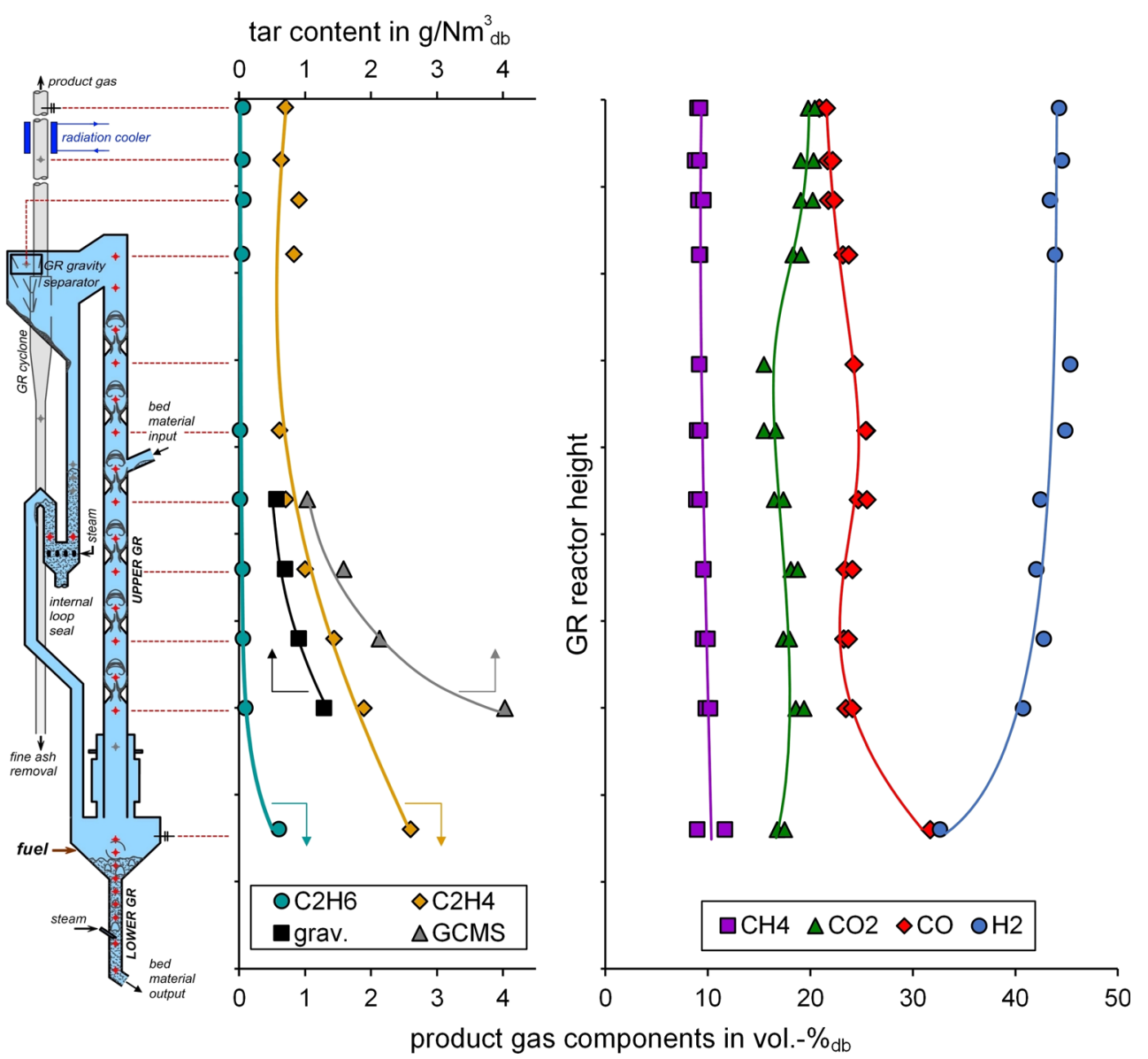

$45 / 55,68 / 32$, and $100 / 0$ vol $\%$ for the specific steady-state operation phases. Figure 24 shows the courses of the main product gas components over the mixture of the gasification agent. With increasing $\mathrm{CO}_{2}$ input, the $\mathrm{H}_{2}$ content decreased while the $\mathrm{CO}$ content increased. $\mathrm{CH}_{4}$ showed a slight

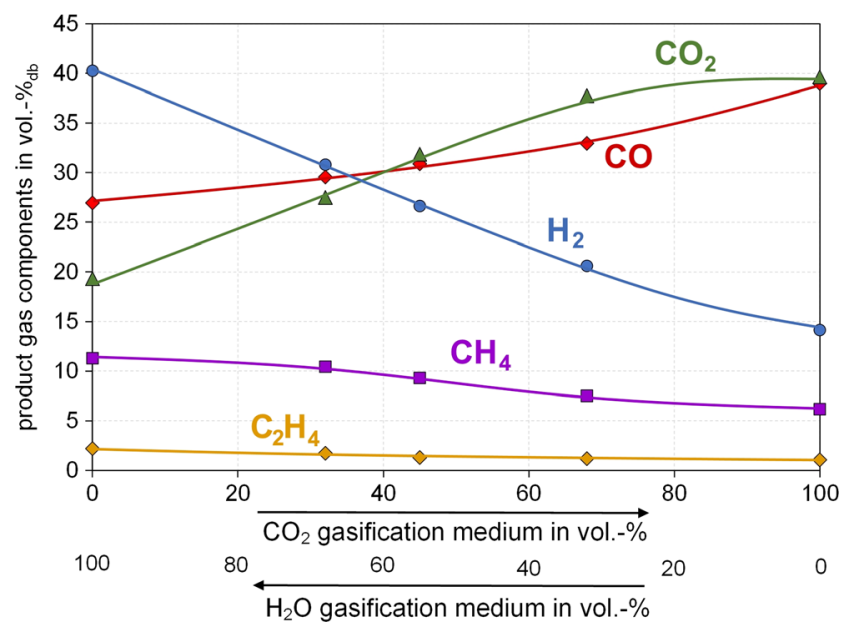

Fig. 24 Influence of $\mathrm{CO}_{2}$ and $\mathrm{H}_{2} \mathrm{O}$ gasification agent mixtures on main product gas components of softwood gasification using olivine as bed material decrease, which could be due to dry reforming reactions. Details of the $\mathrm{CO}_{2}$ gasification experiments at TU Wien and comparable results can be found in [79-81].

\subsection{Sorption-enhanced gasification-description of the process}

Based on the DFB steam gasification principle, further benefits can be obtained by considering the bed material for the fluidized beds. By using limestone (mainly $\mathrm{CaCO}_{3}$ ) or dolomite as bed material, selective transport of $\mathrm{CO}_{2}$ from the GR to the $\mathrm{CR}$, or in other words, from the product gas to the flue gas is possible. The depletion of $\mathrm{CO}_{2}$ in the product gas results in significantly higher $\mathrm{H}_{2}$ (ca. 70-75 vol\%) and $\mathrm{CH}_{4}$ contents (ca. 12-16 vol\%). Using solid biomass as fuel, the special overall process inside the DFB reactor system is a combination of pyrolysis (devolatilization), gasification, and reforming reactions and an internal calcium-looping process. Therefore, different notations of the process like AER (adsorption/absorption-enhanced reforming) [82, 83], SER (sorptionenhanced reforming) [84, 85], CLG (calcium/chemical looping gasification) [86-88], or SEG (sorption-enhanced gasification) $[89,90]$ are found in literature. In the context of 


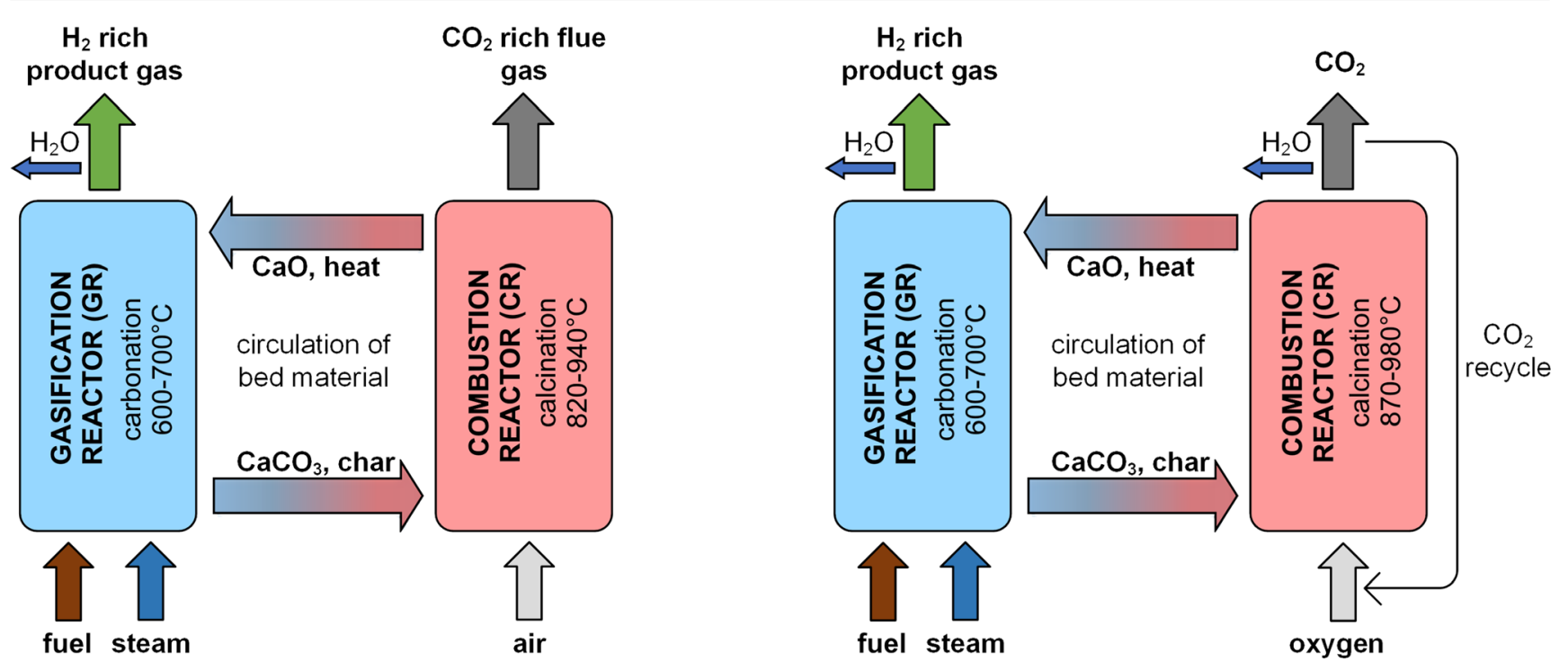

Fig. 25 Basic principle of SEG (left) and Oxy-SEG (right) with limestone as bed material

this publication, the process is called sorption-enhanced gasification (SEG).

SEG is possible by reducing the temperature in the GR to about $650{ }^{\circ} \mathrm{C}$ while keeping the temperature in the $\mathrm{CR}$ above $820^{\circ} \mathrm{C}$. This leads to calcination of the bed material (desorption/release of $\mathrm{CO}_{2}$ ) in the $\mathrm{CR}$ according to Eq. (10) and carbonation (sorption/capture of $\mathrm{CO}_{2}$ ) in the GR according to Eq. (11). Figure 25 (left) shows the basic principle operation of the SEG process in a simplified diagram. A promising adaptation is the combination of the SEG process with oxyfuel combustion (Figure 25, right). Pröll and Hofbauer [91, 92] described this so-called Oxy-SEG process by the usage of pure

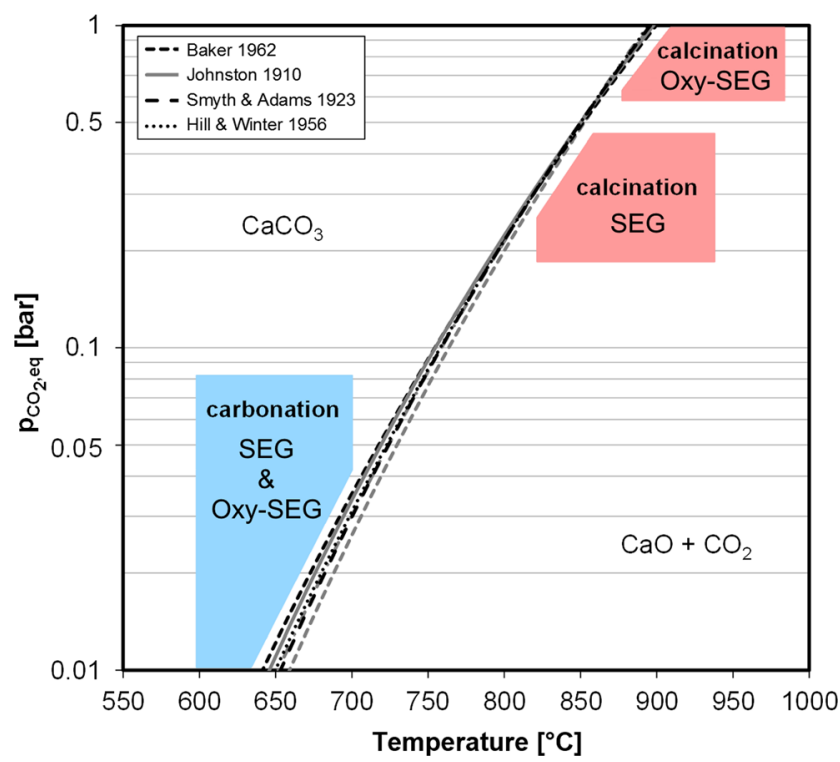

Fig. 26 Typical operation conditions for SEG and Oxy-SEG in the equilibrium diagram of the system $\mathrm{CaCO}_{3} / \mathrm{CaO}$
$\mathrm{O}_{2}$ in combination with flue gas recycling in the CR. Therefore, nearly pure $\mathrm{CO}_{2}$ is the output of the $\mathrm{CR}$ after condensing the water content in this flue gas. If the process parameters are set correctly, no differences of the $\mathrm{H}_{2}$-rich product gas quality are present between SEG and Oxy-SEG [84]. The proposed process could lead to a significant decrease of greenhouse gas emissions when utilizing this flue gas stream for methanation or for transferring the nearly pure $\mathrm{CO}_{2}$ to storage. Therefore, Oxy-SEG enables a below-zero emission technology.

$$
\begin{aligned}
& \mathrm{CaCO}_{3} \rightarrow \mathrm{CaO}+\mathrm{CO}_{2} \Delta H_{R}^{900}=+166 \mathrm{~kJ} / \mathrm{mol} \\
& \mathrm{CaO}+\mathrm{CO}_{2} \rightarrow \mathrm{CaCO}_{3} \quad \Delta H_{R}^{650}=-170 \mathrm{~kJ} / \mathrm{mol} \\
& \mathrm{CO}+\mathrm{H}_{2} \mathrm{O} \leftrightarrow \mathrm{CO}_{2}+\mathrm{H}_{2} \quad \Delta H_{R}^{650}=-36 \mathrm{~kJ} / \mathrm{mol}
\end{aligned}
$$

Based on the equilibrium of the system $\mathrm{CaCO}_{3} / \mathrm{CaO}$, Figure 26 presents the working principles of the SEG and Oxy-SEG in more detail. On the left side of the equilibrium curve, the formation of $\mathrm{CaCO}_{3}$ (carbonation) is favored. Therefore, the GR can be operated on this side of the equilibrium curve. Similarly, the $\mathrm{CR}$ must be operated on the right side (calcination). Owing to the removal of $\mathrm{CO}_{2}$ from the product gas, more $\mathrm{H}_{2}$ is produced by the water-gas shift reaction and by following Le Chatelier's principle (Eq. (12)). The result is a product gas with high $\mathrm{H}_{2}$ content (up to $75 \%$ ) and low $\mathrm{CO}_{2}$ and $\mathrm{CO}$ contents (both below $10 \%$ ). $\mathrm{CO}_{2}$ from the product gas is released into the flue gas by thermal decomposition of $\mathrm{CaCO}_{3}$ in the $\mathrm{CR}$, which leads to $\mathrm{CO}_{2}$-enriched flue gas. Generally, the solid bed material particles leaving the GR are typically not fully carbonated. The presence of catalytically active $\mathrm{CaO}$ helps to improve the product gas quality and reduce the tar content in the product gas. Fuchs et al. [91, 92] 
Fig. 27 Results of test runs with different fuel types and cycle rates during SEG

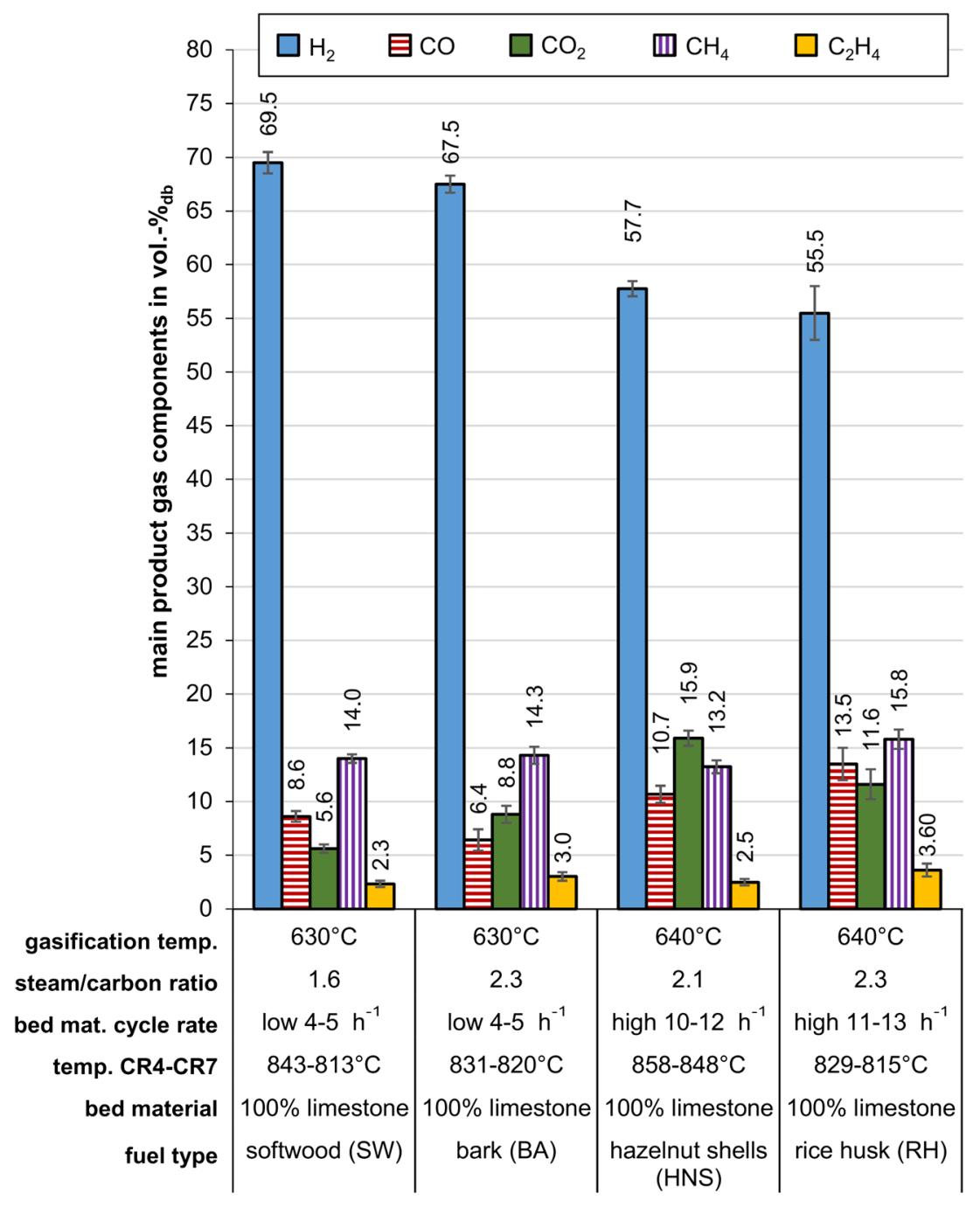

recently published a detailed review of the state-of-the-art of the SEG process.

Compared to the conventional DFB gasification system using olivine as bed material, heat integration in the case of SEG is more complex. The interference of the overall endothermic gasification reactions and the exothermic carbonation reaction, combined with high-temperature difference among the reactors, reduces the amount of heat that needs to be transported from the CR to the GR via circulating the bed material. Thus, lower cycle rates or even cooling of the bed material between the CR and GR is needed. Due to the lower gasification temperature $\left(<700{ }^{\circ} \mathrm{C}\right)$, more char is transported to the CR, which reduces the need for additional fuel [64]. In some cases, the additional fuel input into the CR is not

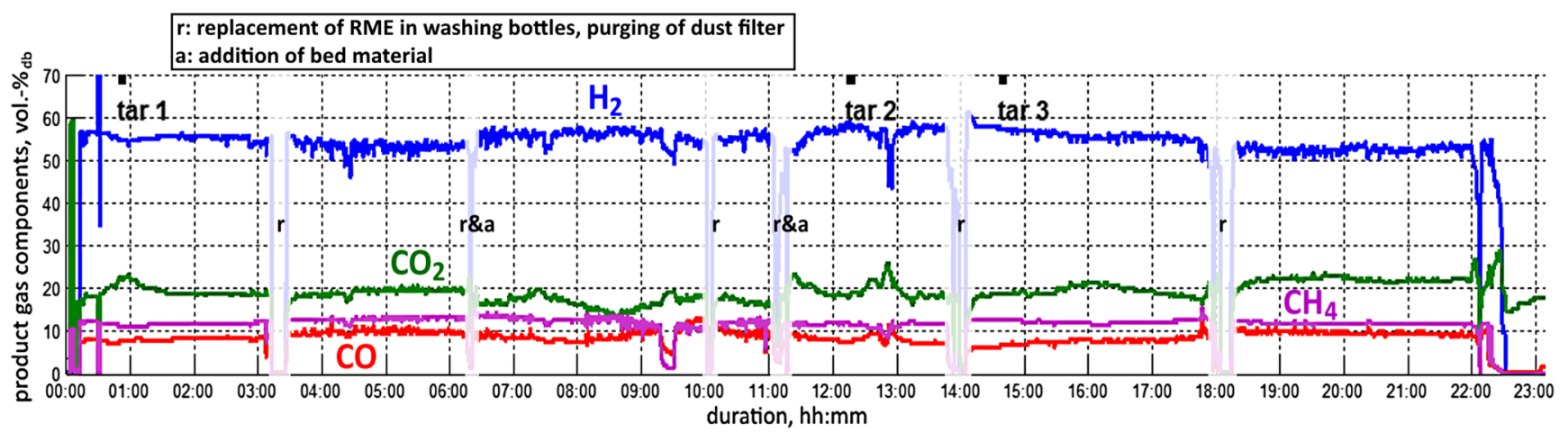

Fig. 28 Long-term SEG test run with a high cycle rate of bed material and softwood as fuel [93] 
Fig. 29 Influence of the gasification temperature with softwood as fuel and pure (fresh) olivine as bed material for steamto-carbon ratios of $1.5-1.8$
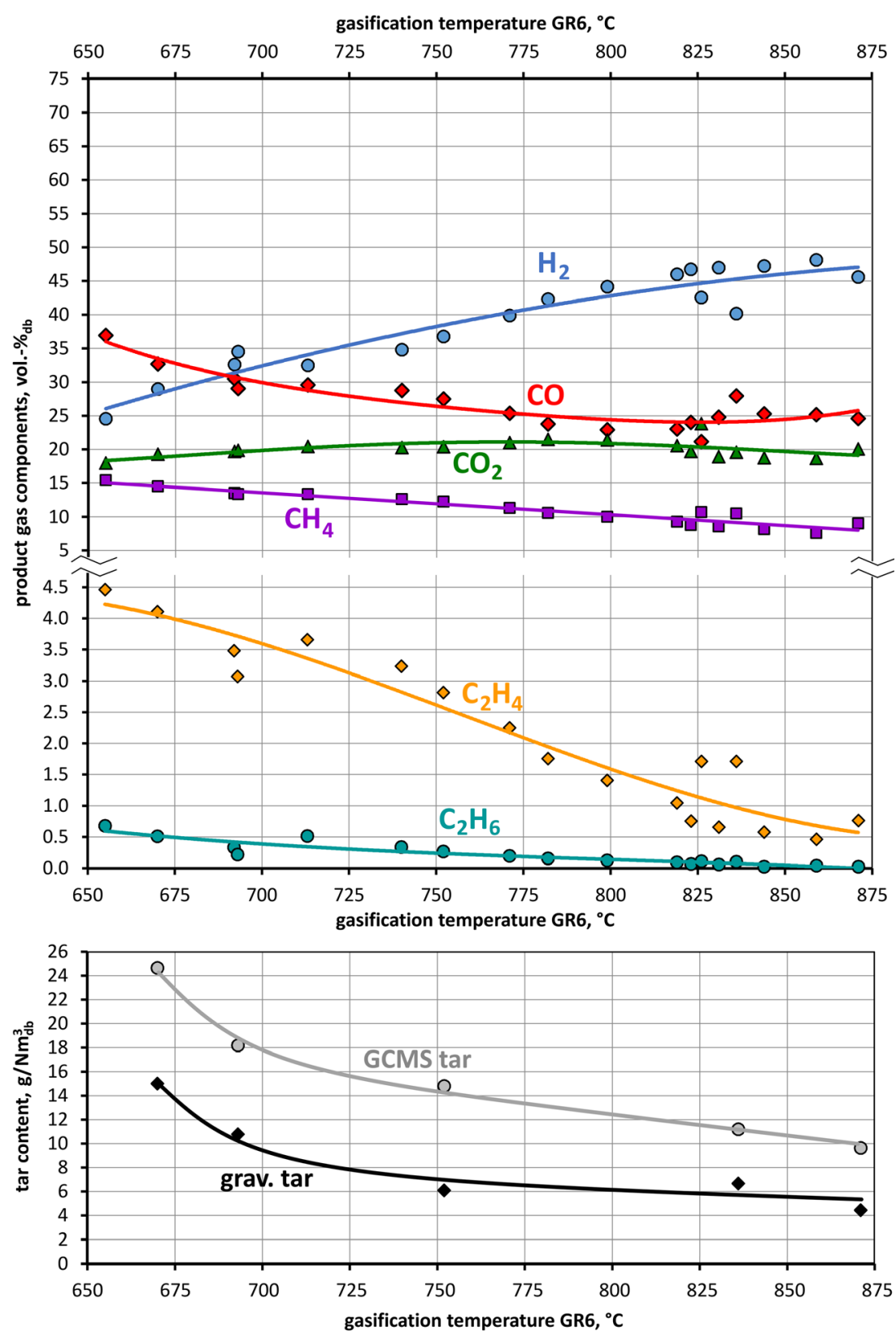

necessary anymore. Owing to the lower temperature level in the system, efficiencies of the SEG process are slightly higher compared to the conventional DFB gasification process.

\subsection{Influence of cycle rate on sorption-enhanced gasification}

The SEG process is highly dependent on the bed material cycle rate, which indicates the hourly turnover of the total bed material inventory. Typically, a low bed material cycle rate leads to high $\mathrm{H}_{2}$ content and low $\mathrm{CO}_{2}$ content in the product gas [93, 94]. Several different fuel types have been successfully tested using the SEG process. Thus, the influence of bed material cycle rate on different fuel types can also be seen in Figure 27. The measurement results show that high cycle rates $\left(>10 \mathrm{~h}^{-1}\right)$ lead to a significantly lower $\mathrm{H}_{2}$ content in the product gas than for low cycle rates $\left(<5 \mathrm{~h}^{-1}\right)$ in the pilot plant of TU Wien. The temperature did not influence these results because the gasification temperature of the presented test runs of Figure 27 was nearly the same in the lower GR $\left(630^{\circ} \mathrm{C}\right.$ vs. $\left.640^{\circ} \mathrm{C}\right)$. These results and the general mechanism of SEG cycle rate variation are discussed in more detail in [64, $94,95]$. It is supposed that the calcination of bed material particles was not sufficient at high cycle rates (lower residence time) in the CR, especially if lower CR temperatures are present at the same time. Thus, the kinetics of bed material calcination in the CR was the limiting factor for an efficient SEG process with high $\mathrm{H}_{2}$ contents in the product gas. 
Fig. 30 Influence of the gasification temperature with softwood as fuel and limestone as bed material for steam-to-carbon ratios of 1.6-1.9
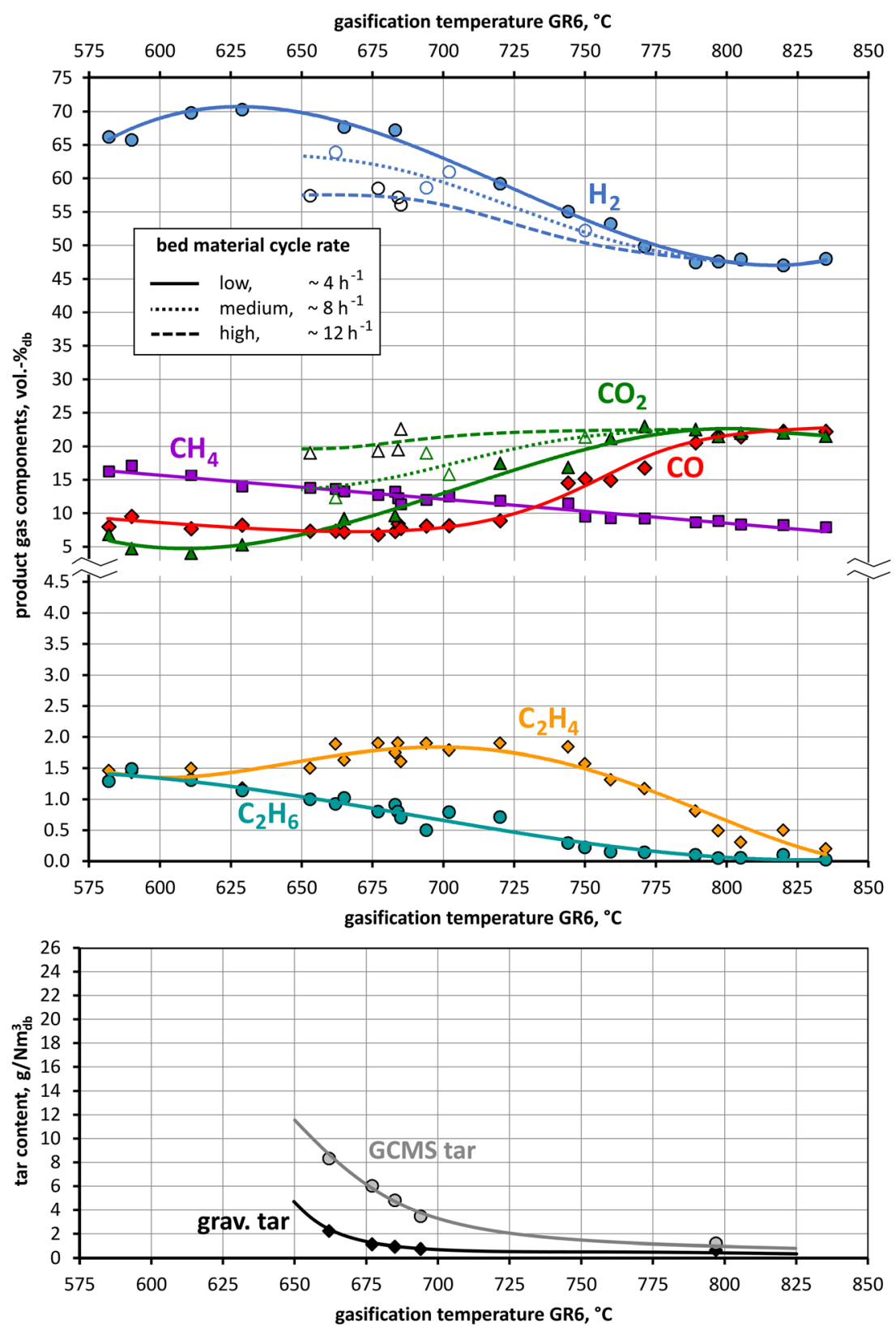

A long-term SEG test run with $22 \mathrm{~h}$ of steady-state operation proved the feasibility of the new pilot plant at TU Wien. Figure 28 shows the main product gas composition during operation. Three tar sampling procedures were conducted during the test run. The bed material cycle rate of the presented SEG test run was high, and the gasification temperature was in the range of 680-690 ${ }^{\circ} \mathrm{C}$. Therefore, the $\mathrm{H}_{2}$ content was limited to ca. 55 vol\%. The visible disturbances of the product gas measurement in Figure 28 were not operational interruptions. At this point, the gas measurement equipment was not operational because gas washing bottles of the online gas measurement had to be renewed. Test runs of industrial scaled plants showed that attrition of bed material particles and the extensive entrainment of fly char led to critical problems during SEG operation [96]. Chemical and thermal stress and predominately the mechanical attrition in high-velocity cyclone separators lead to a fragmentation of limestone particles as comparable soft bed material. As a result, the advanced pilot plant at TU Wien is equipped with gravity separators to minimize abrasion and attrition effects of the bed material. Cyclones follow the gravity separators to minimize the fly ash and dust content in the product gas (cf. Figs. 3 and 5). Additionally, the upper countercurrent part of the GR guarantees a higher fly char conversion and therefore a comparable low char content in the product gas. Thus, no problems were encountered for 


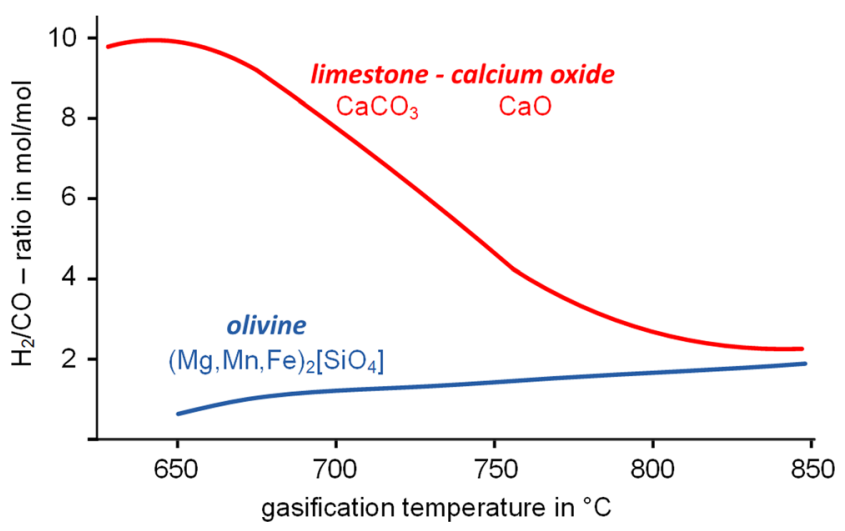

Fig. $31 \mathrm{H}_{2}$-to-CO ratio for the SEG process with limestone as bed material and conventional DFB steam gasification with olivine as bed material and softwood as fuel

the $22 \mathrm{~h}$ test with the pilot plant at TU Wien. Measurements during this long-term test run show typical mean fly char contents of ca. $8 \mathrm{~g} / \mathrm{Nm}^{3}{ }_{\mathrm{db}}$ and dust contents of ca. $17 \mathrm{~g} / \mathrm{Nm}^{3} \mathrm{db}$ in the product gas leaving the GR.

\subsection{Temperature variation}

The gasification temperature is the main factor influencing the product gas composition. Figures 29 and 30 show the variation of the bubbling bed temperature of the lower GR. The resulting product gas composition and tar content are displayed for two different bed material types (limestone and olivine). Softwood was used

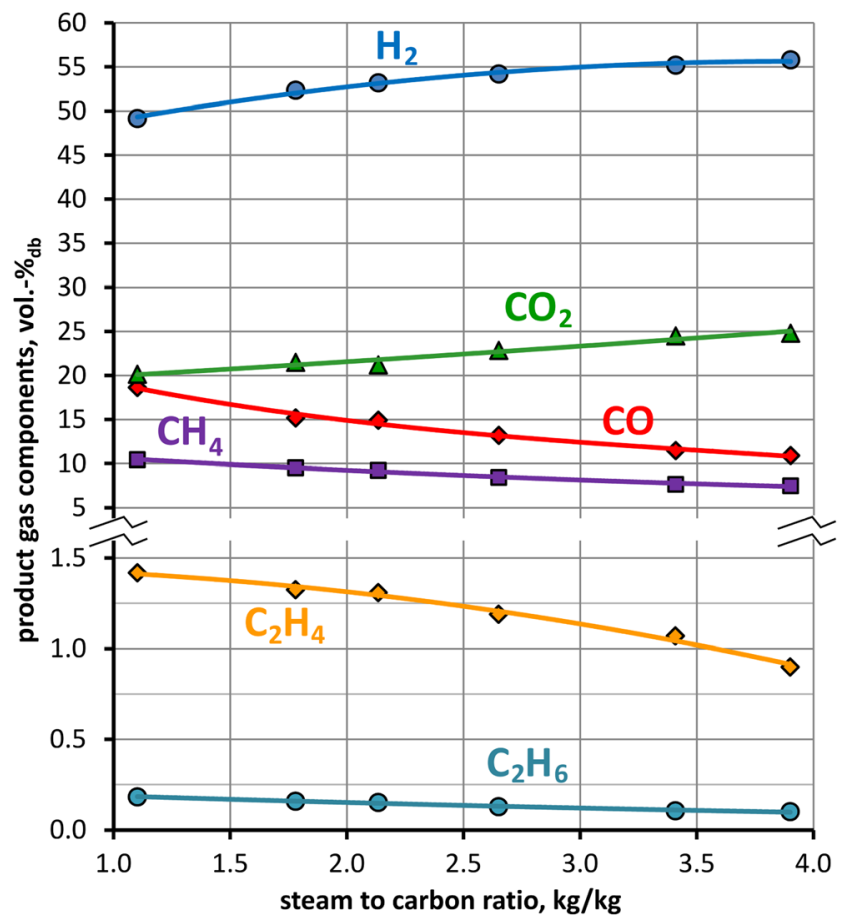

Fig. 32 Variation of steam-to-carbon ratio with softwood as fuel and limestone as bed material at gasification temperatures of $750-760{ }^{\circ} \mathrm{C}$ as fuel for steam gasification in the DFB pilot plant of TU Wien. The steam-to-carbon ratio (Eq. (5)) for the single test runs of temperature variation in Figs. 29 and 30 is in a narrow range of 1.5 to 1.9 . Within the last 5 years, a large number of experiments were necessary to provide the extensive measurement results from steady-state operation phases. Figure 29 (modified and extended from [23]) shows the results for pure and fresh olivine. "Fresh" means that the olivine particles were not activated before the experiments. Thus, they were respectively without calcium-rich layer [59, 61]. Figure 30 (modified and extended from [93, 97]) shows the results when limestone was used as bed material. By comparing both bed material types, a major difference is obvious. On the one hand, increasing gasification temperatures lead to an increase of $\mathrm{H}_{2}$ content in the product gas for the bed material-type olivine. On the other hand, a $\mathrm{CO}_{2}$ transport between the reactors is realized at low gasification temperatures between 600 and $700{ }^{\circ} \mathrm{C}$ using limestone as bed material which leads to an increased $\mathrm{H}_{2}$ content in the product gas. The previous section of this paper explains the fundamental principle of this so-called SEG process. Generally, for both bed materials, the tar content in the product gas is decreasing significantly with increasing temperature, and a strong influence on product gas composition by the gasification temperature is observed. Simulation results presented by Aghaalikhani et al. [98] regarding the measurement data of Figure 29 indicate that the water-gas shift equilibrium is nearly reached at temperatures higher than $800{ }^{\circ} \mathrm{C}$. Figure 30 shows that the use of limestone as bed material offers the possibility to easily set the $\mathrm{H}_{2}$-to- $\mathrm{CO}$ ratio of the product gas by changing either the gasification temperature or the bed material cycle rate. Schmid et al. [99] show that the trend curves of SEG temperature variation of Figure 30 are in perfect accordance with their measurement and simulation data. Simulation results of Fuchs et al. [100] regarding the measurement data of Figure 30 indicate that the water-gas shift equilibrium is nearly reached at temperatures higher than $700{ }^{\circ} \mathrm{C}$. Since $\mathrm{CaO}$ (from calcined limestone) is highly catalytically active, the tar content for limestone as bed material is on a very low basis. Additionally, the usage of fuels with critical ash melting behavior during conventional gasification [65] may be enabled, due to lower system temperatures and the use of limestone, which is assumed to inhibit ash sintering of bed material particles in a wider range than olivine or other bed material types. A closer look on the 3rd test run of Figure 17 (bark as fuel, limestone as bed material) shows a CO content of 14.7 vol\% in the product gas. A comparison with Figure 30 and the results with other fuel types reveals a moderate $\mathrm{CO}_{2}$ transport 
Table 8 Details of product gas components from DFB steam gasification of wood chips, after cooling and primary gas cleaning via fabric filter and bio-diesel scrubber

\begin{tabular}{|c|c|c|c|c|}
\hline & Unit & Mean value & Typical min. & Typical max. \\
\hline \multicolumn{5}{|l|}{ General information } \\
\hline Bed material & - & Olivine & & \\
\hline Fuel type & - & Wood chips & & \\
\hline Gasification temperature & ${ }^{\circ} \mathrm{C}$ & 840 & 830 & 860 \\
\hline Temp. after bio-diesel scrubber & ${ }^{\circ} \mathrm{C}$ & 40 & 35 & 45 \\
\hline Water $\left(\mathrm{H}_{2} \mathrm{O}\right)$ content & vol\% & 8 & 5 & 12 \\
\hline Other gaseous components & vol\% & 92 & 88 & 95 \\
\hline \multicolumn{5}{|l|}{ Product gas components } \\
\hline Hydrogen $\left(\mathrm{H}_{2}\right)$ & $\mathrm{vol}_{\mathrm{db}}$ & 40 & 36 & 44 \\
\hline Carbon monoxide (CO) & $\mathrm{vol}_{\mathrm{db}}$ & 23 & 20 & 29 \\
\hline Carbon dioxide $\left(\mathrm{CO}_{2}\right)$ & $\mathrm{vol}_{\mathrm{db}}$ & 22 & 18 & 25 \\
\hline Methane $\left(\mathrm{CH}_{4}\right)$ & $\mathrm{vol}_{\mathrm{db}}$ & 9.7 & 8 & 12 \\
\hline Acetylene $\left(\mathrm{C}_{2} \mathrm{H}_{2}\right)$ & $\mathrm{vol}_{\mathrm{db}}$ & 0.1 & 0.05 & 0.15 \\
\hline Ethylene $\left(\mathrm{C}_{2} \mathrm{H}_{4}\right)$ & $\mathrm{vol}_{\mathrm{db}}$ & 2.5 & 1.0 & 3.5 \\
\hline Ethane $\left(\mathrm{C}_{2} \mathrm{H}_{6}\right)$ & $\mathrm{vol}_{\mathrm{db}}$ & 0.3 & 0.1 & 0.5 \\
\hline Propane $\left(\mathrm{C}_{3} \mathrm{H}_{8}\right)$ & $\operatorname{vol}_{\mathrm{db}}$ & 0.4 & 0.3 & 0.6 \\
\hline Oxygen $\left(\mathrm{O}_{2}\right)$ & $\mathrm{vol}_{\mathrm{db}}$ & 0.1 & 0.0 & 0.3 \\
\hline Nitrogen $\left(\mathrm{N}_{2}\right)$ & $\mathrm{vol}_{\mathrm{db}}$ & 1.5 & 0.5 & 3.5 \\
\hline Hydrogen sulfide $\left(\mathrm{H}_{2} \mathrm{~S}\right)$ & vol $\mathrm{ppm}_{\mathrm{db}}$ & 60 & 20 & 190 \\
\hline Carbonyl sulfide (COS) & vol $\mathrm{ppm}_{\mathrm{db}}$ & 4 & 0.3 & 8 \\
\hline Thiophene $\left(\mathrm{C}_{4} \mathrm{H}_{4} \mathrm{~S}\right)$ & vol $\mathrm{ppm}_{\mathrm{db}}$ & 10 & 3 & 25 \\
\hline Ammonia $\left(\mathrm{NH}_{3}\right)$ & vol $\mathrm{ppm}_{\mathrm{db}}$ & 950 & 500 & 1800 \\
\hline Mercaptanes (RSH) & vol $\mathrm{ppm}_{\mathrm{db}}$ & 5 & 1 & 10 \\
\hline Hydrogen chloride $(\mathrm{HCl})$ & vol $\mathrm{ppm}_{\mathrm{db}}$ & 2 & 0.2 & 7 \\
\hline Hydrogen cyanide (HCN) & vol ppm $\mathrm{db}_{\mathrm{d}}$ & 10 & 5 & 30 \\
\hline Benzene $\left(\mathrm{C}_{6} \mathrm{H}_{6}\right), \mathrm{B}$ & $\mathrm{mg} / \mathrm{Nm}_{\mathrm{db}}^{3}$ & 14,000 & 7000 & 22,000 \\
\hline Toluene $\left(\mathrm{C}_{7} \mathrm{H}_{8}\right), \mathrm{T}$ & $\mathrm{mg} / \mathrm{Nm}_{\mathrm{db}}^{3}$ & 2800 & 800 & 4000 \\
\hline Ethylbenzene $\left(\mathrm{C}_{6} \mathrm{H}_{5} \mathrm{CH}_{2} \mathrm{CH}_{3}\right), \mathrm{E}$ & $\mathrm{mg} / \mathrm{Nm}_{\mathrm{db}}^{3}$ & 100 & 10 & 300 \\
\hline Xylene $\left(\left(\mathrm{CH}_{3}\right)_{2} \mathrm{C}_{6} \mathrm{H}_{4}\right), \mathrm{X}$ & $\mathrm{mg} / \mathrm{Nm}_{\mathrm{db}}^{3}$ & 250 & 20 & 700 \\
\hline Dust particles & $\mathrm{mg} / \mathrm{Nm}_{\mathrm{db}}^{3}$ & 10 & 5 & 20 \\
\hline Char particles & $\mathrm{mg} / \mathrm{Nm}_{\mathrm{db}}^{3}$ & 8 & 3 & 15 \\
\hline Grav. tar & $\mathrm{mg} / \mathrm{Nm}_{\mathrm{db}}^{3}$ & 140 & 50 & 300 \\
\hline GC-MS tar (without BTEX) ${ }^{\mathrm{a}}$ & $\mathrm{mg} / \mathrm{Nm}_{\mathrm{db}}^{3}$ & 2100 & 330 & 4600 \\
\hline
\end{tabular}

${ }^{\text {a }}$ GC-MS value mainly consists typically of $65-75 \mathrm{wt} \%$ naphthalene, $10-15 \mathrm{wt} \%$ styrene, $8-14 \mathrm{wt} \%$ 1H-indene, $2-3 \mathrm{wt} \%$ acenaphthylene, and $1-2 \mathrm{wt} \%$ phenylacetylene characteristic leading to slightly lower $\mathrm{CO}$ and higher $\mathrm{H}_{2}$ contents of the test run with $748{ }^{\circ} \mathrm{C}$ gasification temperature.

For many synthesis applications, a specific $\mathrm{H}_{2}$-to- $\mathrm{CO}$ ratio is beneficial or necessary. As an example, a $\mathrm{H}_{2}$-to$\mathrm{CO}$ ratio of 3 is necessary for methanation [101]. By applying the SEG process with limestone as bed material, an in situ adaptation of this ratio in the range from about 2 to $10 \mathrm{~mol} / \mathrm{mol}$ is possible (see Figure 31). This is superior to the conventional gasification of using olivine as bed material, where only a $\mathrm{H}_{2}$-to- $\mathrm{CO}$ ratio of about $2 \mathrm{~mol} / \mathrm{mol}$ is possible. An additional reactor (e.g., a water-gas shift reactor) is necessary to reach ratios higher than 2 for conventional gasification at high gasification temperatures [102-104]. Other concepts try to use as much carbon in the product gas as possible to maximize carbon utilization in the fuel. Therefore, the $\mathrm{CO}_{2}$ content of the product gas can also be used as a carbon source for the synthesis process. To reach appropriate $\mathrm{H}_{2}$-to- $\left(\mathrm{CO}+\mathrm{CO}_{2}\right)$ ratios for different synthesis, an additional hydrogen input from electrolysis has been proposed [105-107].

\subsection{Steam-to-carbon variation}

The steam-to-carbon ratio is a parameter, which influences the main product gas composition. The ratio can be adjusted with 


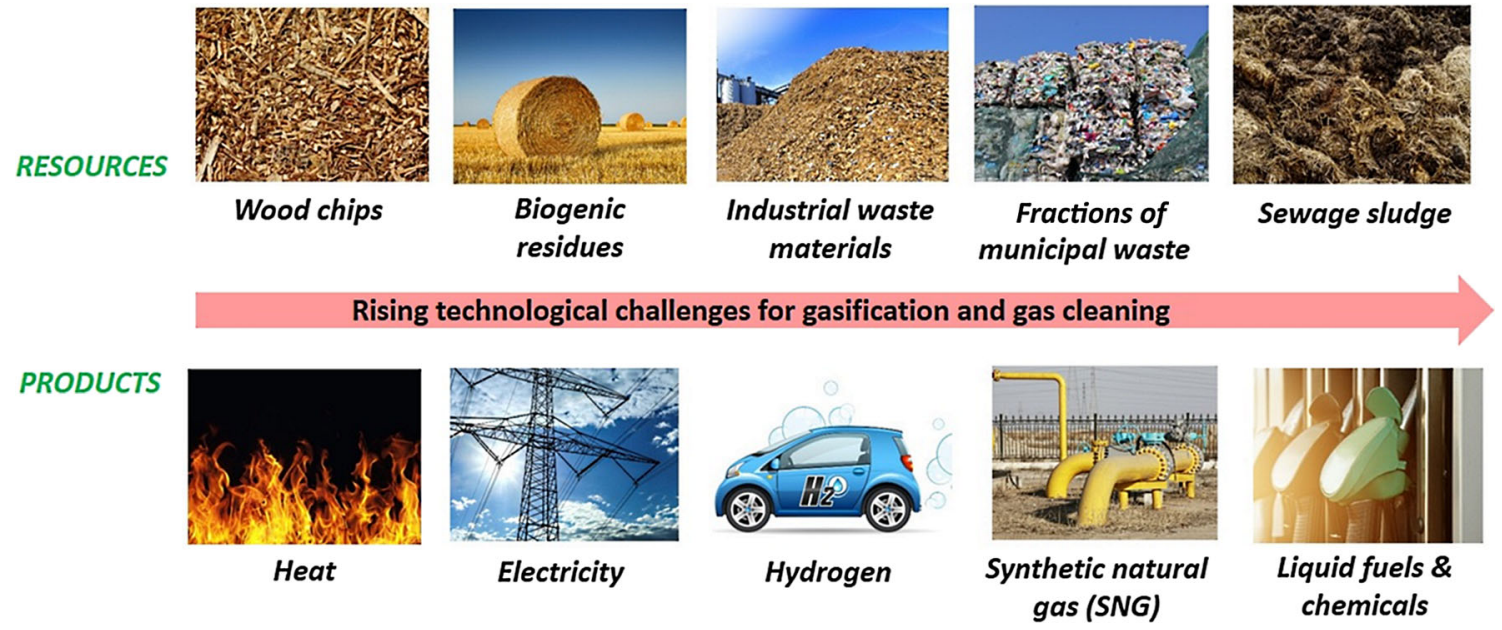

Fig. 33 Future application of gasification technology to gain valuable products from low-grade resources

the steam introduced into the GR and can be used as gasification and fluidization agent for a certain quantity of dry and ash-free fuel (cf. Eq. (5)). Figure 32 presents the results of using limestone as bed material and constant gasification temperatures in the range of $750-760{ }^{\circ} \mathrm{C}$. With increasing steamto-carbon ratio, increasing $\mathrm{H}_{2}$ and $\mathrm{CO}_{2}$ contents and decreasing $\mathrm{CO}$ content occur. The influence of the steam-to-carbon variation on the product gas composition follows similar trends or is in good accordance with previous results presented in $[6,7,108-110]$. It is worthy of note that the $\mathrm{H}_{2}$ and $\mathrm{CO}_{2}$ contents of Figure 32 are slightly higher in comparison to what is available in the literature. This is explained by the promoted water-gas shift reaction, because of the advanced $100 \mathrm{~kW}$ pilot plant design at TU Wien and because catalytically highly active limestone was used as bed material. However, for high overall efficiencies of the DFB gasification system, low steam-to-carbon ratios in the range of 1 to 2 are beneficial, because the steam input flow needs energy for its production and overheating [111].

\subsection{Detailed gas analysis of dual fluidized bed steam gasification}

At TU Wien, extensive internal data is available for the DFB steam gasification of wood chips in different industrial plants. Table 8 presents the values for a typical product gas composition after cooling, dust and fly char removal with a fabric filter and water condensation, and gas cleaning with a bio-diesel (RME) scrubber operating at around $40{ }^{\circ} \mathrm{C}$. Usually, gas engines use the gas as fuel gas to produce electricity. Additional subsequent gas-cleaning equipment is needed for further utilization as syngas in different synthesis processes. The typical ranges for the extensively listed components of the product gas shown in Table 8 can help to design appropriate gas-cleaning lines. In contrast to previously presented experimental results in this paper, the values shown in Table 8 are based on industrial plants designed as classic DFB gasifiers (cf. Figure 1). Benedikt et al. [46, 57] and Müller et al. [64] explain the differences of the reactor designs. If residues or other fuel types like waste materials are used, the product gas composition will change significantly [8, 13, 14, 69] especially for tar contents and composition, other minor components, and catalyst poisons [111].

\section{Summary and outlook}

The global population increases dramatically, as well as the worldwide economy and hunger for energy. The transition toward $\mathrm{CO}_{2}$ emission-free global societies is the most challenging task of both international and national activities. Emissions emanating from the energy industry strongly depend on the use of certain resources and specific technologies. Therefore, the production of gaseous and liquid chemicals as energy carriers from renewable sources and waste materials has been attracting great interest in the last decades. A valuable syngas is necessary for various synthesis processes, leading to different products like Fischer-Tropsch diesel or SNG. Thermochemical gasification of solid fuels enables the production of such gas mixtures in relevant industrial sizes for subsequent syntheses. The DFB steam gasification technology enables the production of a nitrogen-free and hydrogenrich product gas. Additionally, fluidized bed technology offers the possibility to process various fuel types like woody biomass, biogenic residues, and waste materials. Utilizing such fuel types for the energy supply decreases the need for fossil fuels and enables the sustainable elimination of municipal and industrial waste materials. Consequently, gasification 
technologies will have a fundamental role as an integrated part of the so-called biorefineries and will ensure our environmentfriendly energy supply in the future.

The current publication focuses on the presentation of extensive scientific results from experimental research. A review and summary of the various gasification test runs conducted with an advanced $100 \mathrm{~kW}$ gasification pilot plant at TU Wien over the last 5 years are given. The variation of the process parameters and the extensive analysis of the product gas compositions give a detailed insight into the gasification process. Mass and energy balances via the software tool IPSEpro support the scientific validation of measurement results and enable the calculation of performance-indicating key figures. The main outcome is that the advanced reactor design has good preconditions for fuel flexible steam gasification with high conversion efficiencies. The special design of the new reactor system enables the use or the intermixture of soft bed materials like cheap and worldwide-available limestone $(\mathrm{CaO})$, without suffering from high attrition/abrasion rates during hightemperature operation. Catalytically active bed material mixtures lead to process conditions with favorable syngas compositions. Undesired product gas components decrease significantly. By the utilization of standard fuel types like bark or wood, the effort for conditioning the product gas toward suitable and clean syngas is low. The conversion of alternative fuel types like biogenic residues and waste materials is more complex. On the one hand, critical ash components lead to limitations of operation of the fluidized bed system regarding some fuel types. On the other hand, most of the residual fuels were gasified without any problem. Control of the gasification temperature leads to the possibility to influence the product gas composition. Desirable ratios of hydrogen to carbon monoxide in the product gas for synthesis processes are adjustable by the use of limestone as bed material. To sum up, the well-documented data of this paper allows comparisons with other results from research and supports the pursuing scientific work in the field of gasification, gas cleaning, and synthesis processes. Figure 33 indicates which products could be produced from different solid resources as fuel. If high-value green energy carriers from low-value lignocellulosic fuel types are the goal, the presented gasification technology has the potential to be a key energy conversion technology concerning the Paris Climate Targets.

Further, future research should focus on long-term tests using different fuels. Based on the test runs and the data presented in this paper, additional scientific work should be conducted to investigate specific gascleaning equipment and gas-upgrading technologies. Furthermore, different projects are needed to demonstrate optimized process chains, from fuel pretreating until filling the final product into tanks. It is recommended that efforts should be made to avoid big scaling steps for complex process chains, including synthesis processes of syngas. Even though each specific process inside the chain seems to be manageable, experience has shown that a combination of the single processes raises potential risks. However, the results from the gasification test runs presented in this publication and data from other current literature from the authors indicate a good data basis for further development and optimization of valuable combinations of technologies. Figure 33 shows a pathway of the vision, concerning the future strategic development of gasification technology. It would be an outstanding opportunity if SNG and liquid fuels could be produced from lowgrade sources. Finally, further research activities aim at the demonstration of a biorefinery for the emission-free production of chemicals and energy carriers.

Acknowledgments The present work is part of the research project ReGas4Industry in cooperation with the SMS Process Technologies $\mathrm{GmbH}$ and Energy \& Chemical Engineering GmbH. ReGas4Industry receives financial support from the research program "Energieforschung" funded by the "Austrian Climate and Energy Fund". The authors would like to acknowledge the work of the Test Laboratory for Combustion Systems at TU Wien. On behalf of the team at Bioenergy2020+, we like to thank Mr. Matthias Kuba for the permission to use specific data from joint projects. Finally, the anonymous reviewers are gratefully acknowledged for their constructive comments on the paper.

Funding Information Open access funding provided by TU Wien (TUW).

Open Access This article is distributed under the terms of the Creative Commons Attribution 4.0 International License (http:// creativecommons.org/licenses/by/4.0/), which permits unrestricted use, distribution, and reproduction in any medium, provided you give appropriate credit to the original author(s) and the source, provide a link to the Creative Commons license, and indicate if changes were made.

\section{References}

1. Winkler F (1928) Manufacturing fuel gas. US patent $1,687,118$, filed Sep. 27, 1923, patented Oct. 9, 1928

2. Hofbauer H, Stoiber H, Veronik G (1995) Gasification of organic material in a novel fluidized bed system. In: Proceedings of the 1st SCEJ symposium on fluidization, Tokyo, Japan

3. Levenspiel O (2005) What will come after petroleum? Ind Eng Chem Res 44:5073-5078. https://doi.org/10.1021/ie040169b

4. Karl J, Pröll T (2018) Steam gasification of biomass in dual fluidized bed gasifiers: a review. Renew Sust Energ Rev 98:64-78. https://doi.org/10.1016/j.rser.2018.09.010

5. Kirnbauer F, Wilk V, Hofbauer H (2012) Performance improvement of dual fluidized bed gasifiers by temperature reduction: the behavior of tar species in the product gas. Fuel 108:534-542. https://doi.org/10.1016/j.fuel.2012.11.065 
6. Hofbauer H, Rauch R (2000) Stoichiometric water consumption of steam gasification by the FICFB-gasification process. Thermochemical Biomass Conversion, A.V. Bridgwater (Editor), ISBN: 978-0-470-69484-8. https://doi.org/10.1002/ 9780470694954.ch14

7. Pfeifer C, Koppatz S, Hofbauer H (2011) Steam gasification of various feedstocks at a dual fluidized bed gasifier: impacts of operation conditions and bed materials. Biomass Conv. Bioref. 1:39-53. https://doi.org/10.1007/s13399-011-0007-1

8. Schmid JC, Wolfesberger U, Koppatz S, Pfeifer C, Hofbauer H (2012) Variation of feedstock in a dual fluidized bed steam gasifier - influence on product gas, tar content, and composition. Environ Prog Sustain Energy 31:205-215. https://doi.org/10. 1002/ep. 11607

9. Kitzler H (2013) Zweibettwirbelschicht-Dampfvergasung von biogenen, ascheintensiven Brenn- und Reststoffen - Einfluss der Asche auf den Prozess. Doctoral thesis, TU Wien, Austria

10. Schmid JC (2016) Technoökonomische Fallstudien als Entscheidungsunterstützung für das strategische Management. MBA Master Thesis, Austrian Institute of Management, FH Burgenland

11. Jingang Y, Kraussler M, Benedikt F, Hofbauer H (2017) Technoeconomic assessment of hydrogen production based on dual fluidized bed biomass steam gasification, biogas steam reforming, and alkaline water electrolysis processes. Energy Convers Manag 145:278-292. https://doi.org/10.1016/j.enconman.2017. 04.084

12. Müller S (2013) Hydrogen from biomass for industry - industrial application of hydrogen production based on dual fluid gasification. Doctoral thesis, TU Wien, Austria. ISBN 978-3-9502754-5-2

13. Wilk V, Kern S, Kitzler H, Koppatz S, Schmid JC, Hofbauer H (2011) Gasification of plastic residues in a dual fluidized bed gasifier - characteristics and performance compared to biomass. In: Proceedings of the International Conference on Polygeneration Strategies (ICPS11), Vienna, Austria

14. Schweitzer D, Gredinger A, Schmid M, Waizmann G, Beirow M, Spörl R, Scheffknecht G (2018) Steam gasification of wood pellets, sewage sludge and manure: gasification performance and concentration of impurities. Biomass Bioenergy 111:308-319. https://doi.org/10.1016/j.biombioe.2017.02.002

15. Wilk V, Hofbauer H (2013) Co-gasification of plastics and biomass in a dual fluidized-bed steam gasifier: possible interactions of fuels. Energy Fuels 27:3261-3273. https://doi.org/10.1021/ ef $400349 k$

16. Schmid JC, Pröll T, Kitzler H, Pfeifer C, Hofbauer H (2012) Cold flow model investigations of the countercurrent flow of a dual circulating fluidized bed gasifier. Biomass Conv. Bioref. 2:229 244. https://doi.org/10.1007/s13399-012-0035-5

17. Pfeifer C, Schmid JC, Pröll T, Hofbauer H (2011) Next generation biomass gasifier. In: Proceedings of the 19th European Biomass Conference, Berlin, Germany. https://doi.org/10.5071/ 19thEUBCE2011-VP2.3.24

18. Schmid JC (2014) Development of a novel dual fluidized bed gasification system for increased fuel flexibility. Doctoral thesis, TU Wien, Austria. ISBN 978-3-9502754-6-9

19. Diem, R (2015) Design, construction and startup of an advanced $100 \mathrm{~kW}$ dual fluidized bed system for thermal gasification. Doctoral thesis, TU Wien, Austria. ISBN 978-3-9502754-7-6

20. Benedikt F, Schmid JC, Hofbauer H (2017) Enhanced dual fluidized bed gasification using calcium oxide as bed material. In: Proceedings 13. Minisymposium Verfahrenstchnik, 29-30. March 2017, Innsbruck, Austria

21. Kolbitsch M (2106) First fuel tests at a novel $100 \mathrm{kWth}$ dual fluidized bed steam gasification pilot plant. Doctoral thesis, TU Wien, Austria. ISBN 978-3-9503671-0-2
22. Pasteiner H, Schmid JC, Müller S, Hofbauer H (2015) Cold flow investigations on a novel dual fluidized bed steam gasification test plant. In: Proceedings 11. Minisymposium der Verfahrenstechnik, 14-15. April 2015 Vienna, Austria

23. Schmid JC, Müller S, Hofbauer H (2016) First scientific results with the novel dual fluidized bed gasification test facility at TU Wien. In: Proceedings of the 24th European biomass conference and exhibition, Amsterdam, The Netherlands. https://doi.org/10. 5071/24thEUBCE2016-2CV.3.16

24. Schmid JC, Pröll T, Pfeifer C, Hofbauer H (2011) Improvement of gas-solid interaction in dual circulating fluidized bed systems. In: Proceedings of the 9th European Conference on Industrial Furnaces and Boilers (INFUB-9), Estoril, Portugal

25. Schmid JC, Pröll T, Pfeifer C, Rauch R, Hofbauer H (2012) Cold flow model investigation on a modified riser with enhanced gassolid contact - locating the regions of operation in a fluidization regime map. In: Proceedings of the 21st international conference on fluidized bed combustion (FBC), Naples, Italy. ISBN 978-8889677-83-4

26. Fuchs J, Schmid JC, Hofbauer H (2 01013$)$ Kaltmodelluntersuchungen zu einer innovativen Zweibettwirbelschicht. In: Proceedings 9. Minisymposium für Verfahrenstechnik, Leoben, Austria

27. Fuchs J (2013) Ermittlung des Betriebskennfeldes einer innovativen Zweibettwirbelschicht anhand von Kaltmodelluntersuchungen. Master thesis, MU Leoben, Austria

28. Lunzer A (2018) CPFD simulation in barracuda VR of a novel dual fluid bed cold flow model. Master thesis, TU Wien, Austria

29. Stollhof M, Penthor S, Piesenberger S, Hofbauer H (2019) Influencing the solid fraction distribution in a circulating fluidized bed system using differently shaped internals. Chem Eng Res Des 146:449-463. https://doi.org/10.1016/j.cherd.2019.04.024

30. Grace JR (1986) Contacting modes and behavior classification of gas-solid and other two-phase suspensions. Can J Chem Eng 64: 353-363. https://doi.org/10.1002/cjce.5450640301

31. Reh L (1961) Das Wirbeln von körnigem Gut im schlanken Diffusor als Grenzzustand zwischen Wirbelschicht und pneumatischer Förderung. Doctoral thesis, TH Karlsruhe, Germany

32. Rabinovich E, Kalman H (2011) Flow regime diagram for vertical pneumatic conveying and fluidized bed systems. Powder Technol 207:119-133. https://doi.org/10.1016/j.powtec.2010.10.017

33. Grace JR (1982) Fluidized bed hydrodynamics. In: Hetsroni G (ed) Handbook of multiphase systems, chapter 8.1, hemisphere, Washington DC

34. Bi HT, Grace JR (1995) Flow regime diagrams for gas-solid fluidization and upward transport. Int J Multiphase Flow 21:1229 1236. https://doi.org/10.1016/0301-9322(95)00037-X

35. Haider A, Levenspiel O (1989) Drag coefficient and terminal velocity of spherical and nonspherical particles. Powder Technol 58: 63-70. https://doi.org/10.1016/0032-5910(89)80008-7

36. Kunii D, Levenspiel O (1997) Circulating fluidized-bed reactors. Chem Eng Sci 52:2471-2482. https://doi.org/10.1016/S00092509(97)00066-3

37. Lim KS, Zhu JX, Grace JR (1995) Hydrodynamics of gas-solid fluidization. Int J Multiphase Flow 21 21:141-193. https://oi.org/ 10.1016/0301-9322(95)00038-Y

38. Martinovic D (2013) Kaltmodellversuche und MSR-Konzept einer Zweibett-Wirbelschicht-Vergasungsanlage. Diplomarbeit. Master thesis, TU Wien, Austria

39. Pasteiner HA (2015) Cold flow investigations on a novel dual fluidised bed steam gasification test plant. Master Thesis, TU Wien, Austria

40. Bickel A (2018) Untersuchungen zu den Scalingkriterien an einer Zweibett-Wirbelschicht-Vergasungsanlage. Master Thesis, TU Wien, Austria 
41. Geldart D (1973) Types of gas fluidization. Powder Technol 7: 285-292. https://doi.org/10.1016/0032-5910(73)80037-3

42. Yang WC (2007) Modification and re-interpretation of Geldart's classification of powders. Powder Technol 171:59-74. https://doi. org/10.1016/j.powtec.2006.08.024

43. Glicksman LR (1984) Scaling relationships for fluidized beds. Chem Eng Sci 39:1373-1379. https://doi.org/10.1016/00092509(84)80070-6

44. Glicksman LR, Hyre M, Woloshun K (1993) Simplified scaling relationships for fluidized beds. Powder Technol 77:177-199. https://doi.org/10.1016/0032-5910(93)80055-F

45. Fuchs J, Schmid JC, Benedikt F, Mauerhofer AM, Müller S, Hofbauer H (2018) A general method for the determination of the entrainment in fluidized beds. Int. Jnl. of Multiphysics 12: 359-371. https://doi.org/10.21152/1750-9548.12.4.359

46. Benedikt F, Fuchs J, Schmid JC, Müller S, Hofbauer H (2017) Advanced dual fluidized bed steam gasification of wood and lignite with calcite as bed material. Korean J Chem Eng 34:25482558. https://doi.org/10.1007/s11814-017-0141-y

47. Schmalzl M (2014) Implementierung der MSR-Technik einer $100 \mathrm{~kW}$ DUAL FLUID Versuchsanlage zur Vergasung von Festbrennstoffen. Master thesis, TU Wien, Austria

48. Mauerhofer AM, Schmid JC, Benedikt F, Fuchs J, Müller S, Hofbauer H (2018) Dual fluidized bed steam gasification: change of product gas quality along the reactor height. Energy 173:12561272. https://doi.org/10.1016/j.energy.2019.02.025

49. Aranda Almansan G, Mourao Vilela C, Vreugdenhil BJ, et al (2018) Gas analysis in gasification of biomass and waste. Guideline report (document 1 \& document 2), IEA bioenergy, ISBN 978-1-910154-47-2

50. Neeft JPA, Knoef H, Zielke U, Sjöströrn K, Hasler P, Simell PA, Dorrington MA, Abatzoglou N, Deutch S, Greil C, Buffinga GJ, Brage C, Suomalainen M (1999) Guideline for sampling and analysis of tar and particles in biomass producer gases. Tar protocol, version 3.1. European Energy project EEN5-1999-00507

51. Wolfesberger U, Aigner I, Hofbauer H (2009) Tar content and composition in producer gas of fluidized bed gasification of wood-influence of temperature and pressure. Environ Prog Sustain Energy 28:372-379. https://doi.org/10.1002/ep.10387

52. Milne TA, Evans RJ (1998) Biomass gasifier "tars": their nature, formation, and conversion. Technical report, National Renewable Energy Laboratory, USA. https://doi.org/10.2172/3726

53. Rabou LPLM, Zwart RWR, Vreugdenhil BJ, Bos L (2009) Tar in biomass producer gas, the energy research Centre of The Netherlands (ECN) experience: an enduring challenge. Energy Fuels 23:6189-6198. https://doi.org/10.1021/ef9007032

54. Morf P, Hasler P, Nussbaumer T (2002) Mechanisms and kinetics of homogeneous secondary reactions of tar from continuous pyrolysis of wood chips. Fuel 81:843-853. https://doi.org/10.1016/ S0016-2361(01)00216-2

55. Elliott DC (1988) Relation of reaction time and temperature to chemical composition of pyrolysis oils. In: Pyrolysis oils from biomass, chapter 6:55-65. https://doi.org/10.1021/bk-1988-0376. ch006

56. Kern S (2013) Gasification and co-gasification of coal, biomass and plastics in a dual fluidized bed system. Doctoral thesis, TU Wien, Austria

57. Benedikt F, Kuba M, Schmid JC, Müller S, Hofbauer H (2019) Assessment of correlations between tar and product gas composition in dual fluidized bed steam gasification for online tar prediction. Appl Energy 238:1138-1149. https://doi.org/10.1016/j. apenergy.2019.01.181

58. Kaltschmitt M, Hartmann H, Hofbauer H (2016) Energie aus Biomasse-Grundlagen, Technik und Verfahren. 3. Auflage, Springer Verlag. https://doi.org/10.1007/978-3-662-47438-9
59. Seemann M., Marinkovic J., Thunman H. (2016) Understanding the start-up- knowledge transfer from bed material testing at Chalmers to the operation of the gobigas gasification unit. In: Proceedings of the 24th European Biomass Conference and Exhibition, Amsterdam, The Netherlands. https://doi.org/10. 5071/24thEUBCE2016-2BO.14.1

60. Berdugo Vilches T, Seemann M, Thunman H (2018) Influence of in-bed catalysis by ash-coated olivine on tar formation in steam gasification of biomass. Energy Fuel 32:9592-9604. https://doi. org/10.1021/acs.energyfuels.8b02153

61. Kirnbauer F, Wilk V, Kitzler H, Kern S, Hofbauer H (2012) The positive effects of bed material coating on tar reduction in a dual fluidized bed gasifier. Fuel 95:553-562. https://doi.org/10.1016/j. fuel.2011.10.066

62. Weber G, Di Giuliano A, Rauch R, Hofbauer H (2016) Developing a simulation model for a mixed alcohol synthesis reactor and validation of experimental data in IPSEpro. Fuel Process Technol 141:167-176. https://doi.org/10.1016/j.fuproc. 2015.05.024

63. Pröll T, Hofbauer H (2008) Development and application of a simulation tool for biomass gasification based processes. Int $\mathrm{J}$ Chem React Eng 6:A89. https://doi.org/10.2202/1542-6580.1769

64. Müller S, Fuchs J, Schmid JC, Benedikt F, Hofbauer H (2017) Experimental development of sorption enhanced reforming by the use of an advanced gasification test plant. Int J Hydrog Energy 42: 29697-29707. https://doi.org/10.1016/j.ijhydene.2017.10.119

65. Fuchs J, Müller S, Hofbauer H (2017) Ash related limitations of dual fluidized bed steam gasification. In: Proceedings 13. Minisymposium Verfahrenstchnik, 29-30. March 2017, Innsbruck, Austria

66. Wilk V, Hofbauer H (2013) Conversion of fuel nitrogen in a dual fluidized bed steam gasifier. Fuel 106:793-801. https://doi.org/10. 1016/j.fuel.2012.12.056

67. Wilk V, Aichernig C, Hofbauer H (2011) Waste wood gasification: distribution of nitrogen, sulphur and chlorine in a dual fluidised bed gasifier. 10th International Conference on Circulating Fluidized Bed Technology (CFB10), May 1-5, 2011, Sunriver, Oregon, USA

68. Kotik J (2010) Über den Einsatz von Kraft-WärmeKopplungsanlagen auf Basis der WirbelschichtDampfvergasung fester Biomasse am Beispiel des Biomassekraftwerks Oberwart. Doctoral thesis, TU Wien, Austria

69. Benedikt F, Schmid JC, Fuchs J, Mauerhofer AM, Müller S, Hofbauer H (2018) Fuel flexible gasification with an advanced $100 \mathrm{~kW}$ dual fluidized bed steam gasification pilot plant. Energy 164:329-343. https://doi.org/10.1016/j.energy.2018.08.146

70. Wilk V (2013) Extending the range of feedstock of the dual fluidized bed gasification process towards residues and waste. Doctoral thesis, TU Wien

71. Rauch R, Pfeifer C, Bosch K, Hofbauer H, Swierczynski D, Courson C, Kiennemann A (2004) Comparison of different olivines for biomass gasification. Proceedings of the Conference for Science in Thermal and Chemical Biomass Conversion, Victoria, Canada

72. Kirnbauer F, Hofbauer H (2011) Investigations on bed material changes in a dual fluidized bed steam gasification plant in Güssing, Austria. Energy Fuels 25:3793-3798. https://doi.org/ 10.1021/ef200746c

73. Kuba M, Havlik F, Kirnbauer F, Hofbauer H (2015) Influence of bed material coatings on the water-gas-shift reaction and steam reforming of toluene as tar model compound of biomass gasification. Biomass Bioenergy 89:40-49. https://doi.org/10.1016/j. biombioe.2015.11.029

74. Pfeifer C, Koppatz S, Hofbauer H (2011) Catalysts for dual fluidised bed biomass gasification - an experimental study at the 
pilot plant scale. Biomass Conv. Bioref. 1:63-74. https://doi.org/ 10.1007/s13399-011-0005-3

75. Mauerhofer AM, Benedikt F, Schmid JC, Fuchs J, Müller S, Hofbauer H (2018) Influence of different bed material mixtures on dual fluidized bed steam gasification. Energy 157:957-968. https://doi.org/10.1016/j.energy.2018.05.158

76. Jeremiáš M, Pohořelý M, Svoboda K, Skoblia S, Beňo Z, Šyc M (2018) $\mathrm{CO}_{2}$ gasification of biomass: the effect of lime concentration in a fluidised bed. Energy 217:361-368. https://doi.org/10. 1016/j.apenergy.2018.02.151

77. Schmid JC, Pfeifer C, Kitzler H, Pröll T, Hofbauer H (2011) A new dual fluidized bed gasifier design for improved in situ conversion of hydrocarbons. In: Proceedings of the International Conference on Polygeneration Strategies (ICPS11), 30 Aug.-1 Sept. 2011, Vienna, Austria

78. Freni S, Calogero G, Cavallaro S (2000) Hydrogen production from methane through catalytic partial oxidation reactions. J Power Sources 87:28-38. https://doi.org/10.1016/S03787753(99)00357-2

79. Mauerhofer AM, Schmid JC, Benedikt F, Fuchs J, Müller S, Hofbauer $\mathrm{H}$ (2019) $\mathrm{CO}_{2}$ gasification in a dual fluidized bed reactor system: impact on the product gas composition. Fuel 253:16051616. https://doi.org/10.1016/j.fuel.2019.04.168

80. Jeremiáš M, Pohořelý M, Svoboda K, Manovic V, Anthony EJ, Skoblia S, Beňo Z, Šyc M (2009) Gasification of biomass with $\mathrm{CO}_{2}$ and $\mathrm{H}_{2} \mathrm{O}$ mixtures in a catalytic fluidised bed. Fuel 210:605610. https://doi.org/10.1016/j.fuel.2017.09.006

81. Stec M, Czaplicki A, Tomaszewicz G, Słowik K (2008) Effect of $\mathrm{CO}_{2}$ addition on lignite gasification in a CFB reactor: a pilot-scale study. Korean J Chem Eng 35:129-136. https://doi.org/10.1007/ s11814-017-0275-y

82. Marquard-Möllenstedt T, Sichler P, Specht M, et al (2004) New approach for biomass gasification to hydrogen. In: Proceedings of the 2nd World Conference on Biomass Energy, Industry and Climate Protection, Rome, Italy

83. Pfeifer C, Puchner B, Hofbauer H (2007) In-situ $\mathrm{CO}_{2}$-absorption in a dual fluidized bed biomass steam gasifier to produce a hydrogen rich syngas. Int J Chem React Eng 5:1-13. https://doi.org/10. 2202/1542-6580.1395

84. Schweitzer D, Beirow M, Gredinger A, Armbrust N, Waizmann G, Dieter H, Scheffknecht G (2016) Pilot-scale demonstration of oxy-SER steam gasification: production of syngas with precombustion $\mathrm{CO}_{2}$ capture. Energy Procedia 86:56-68. https://doi. org/10.1016/j.egypro.2016.01.007

85. Diem R, Müller S, Fuchs M, Schmid JC, Hofbauer H (2014) Sorption-enhanced reforming with limestone from iron production. Biomass Conv. Bioref. 5:95-102. https://doi.org/10.1007/ s13399-014-0149-z

86. Chen S, Wang D, Xue Z, Sun X, Xiang W (2011) Calcium looping gasification for high-concentration hydrogen production with $\mathrm{CO}_{2}$ capture in a novel compact fluidized bed: simulation and operation requirements. Int J Hydrog Energy 36:4887-4899. https://doi.org/ 10.1016/j.ijhydene.2010.12.130

87. Acharya B, Dutta A, Basu P (2017) Gasification of biomass in a circulating fluidized bed based calcium looping gasifier for hydrogen-enriched gas production: experimental studies. Biofuels 8:643-650. https://doi.org/10.1080/17597269.2015. 1118782

88. Udomsirichakorn J, Basu P, Abdul Salam P, Acharya B (2014) $\mathrm{CaO}$-based chemical looping gasification of biomass for hydrogen-enriched gas production with in situ $\mathrm{CO}_{2}$ capture and tar reduction. Fuel Process Technol 127:7-12. https://doi.org/10. 1016/j.fuproc.2014.06.007

89. Fermoso J, Rubiera F, Chen D (2012) Sorption enhanced catalytic steam gasification process: a direct route from lignocellulosic biomass to high purity hydrogen. Energy Environ Sci 5:6358 6367. https://doi.org/10.1039/C2EE02593K

90. Pfeifer C (2013) Sorption-enhanced gasification. In: Fluidized bed technologies for near-zero emission combustion and gasification, chapter 22. https://doi.org/10.1533/9780857098801.4.971

91. Fuchs J, Schmid JC, Müller S, Hofbauer H (2019) Dual fluidized bed gasification of biomass with selective carbon dioxide removal and limestone as bed material: a review. Renew Sust Energ Rev 107:212-231. https://doi.org/10.1016/j.rser.2019.03.013

92. Pröll T, Hofbauer $\mathrm{H}(2008) \mathrm{H}_{2}$ rich syngas by selective $\mathrm{CO}_{2}$ removal from biomass gasification in a dual fluidized bed systemprocess modelling approach. Fuel Process Technol 89:12071217. https://doi.org/10.1016/j.fuproc.2008.05.020

93. Schmid JC, Fuchs J, Benedikt F, Mauerhofer AM, Müller S, Hofbauer H., Stocker H, Kieberger N, Bürgler T (2017) Sorption enhanced reforming with the novel dual fluidized bed test plant at TU Wien. In: Proceedings of the 25th European Biomass Conference and Exhibition, Stockholm, Sweden. https://doi.org/10.5071/25thEUBCE2017-2BO.2.2

94. Fuchs J, Schmid JC, Benedikt F, Müller S, Hofbauer H, Stocker H, Kieberger N, Bürgler T (2018) The impact of bed material cycle rate on in-situ $\mathrm{CO}_{2}$ removal for sorption enhanced reforming of different fuel types. Energy 162:35-44. https://doi.org/10.1016/j. energy.2018.07.199

95. Fuchs J, Schmid JC, Benedikt F, Mauerhofer AM, Penthor S, Müller S, et al (2018) Influence of bed material cycle rate and temperatures on the $\mathrm{CO}_{2}$ transport during sorption enhanced reforming of biomass. 5th International Conference on Chemical Looping, Park City, Utah

96. Koppatz S (2008) In-situ Produktgaskonditionierung durch selektive $\mathrm{CO}_{2}$-Abscheidung bei Wirbelschicht-Dampfvergasung von Biomasse: Machbarkeitsnachweis im industriellen Maßstab. Master thesis, Brandenburg University of Technology, Cottbus, Germany

97. Fuchs J, Müller S, Benedikt F, Schmid JC, Hofbauer H (2016) Optimization of sorption enhanced reforming by the use of an advanced gasification test plant at TU Wien. At: 5 th International Symposium on Gasification and its Applications (iSGA-5), 29.Nov.-01.Dec.2016, Busan, Korea

98. Aghaalikhani A, Schmid JC, Borello D, Fuchs J, Benedikt F, Hofbauer H, Rispoli F, Henriksen UB, Sárossy Z, Cedola L (2019) Detailed modelling of biomass steam gasification in a dual fluidized bed gasifier with temperature variation. Renew Energy 143:703-718. https://doi.org/10.1016/j.renene.2019.05.022

99. Schmid M, Schweitzer D, Beirow M, Dieter H, Scheffknecht G (2015) Gasification of biomass with the Oxy-SER process for syngas production with in situ $\mathrm{CO}_{2}$ capture in a $200 \mathrm{kWth}$ pilot plant. At: IEAGHG's 6th High Temperature Solid Looping Cycle Network Meeting, 2.Sept.2015, Milan, Italy

100. Fuchs J, Schmid JC, Müller S, Mauerhofer AM, Benedikt F, Hofbauer H (2019) The impact of gasification temperature on the process characteristics of sorption-enhanced reforming of biomass. Biomass Conv. Bioref.. https://doi.org/10.1007/s13399019-00439-9

101. Rauch R, Hrbek J, Hofbauer H (2014) Biomass gasification for synthesis gas production and applications of the syngas. WIREs Energy Environ 3:343-362. https://doi.org/10.1002/wene.97

102. Benedikt F, Kraussler M, Konlechner D, Klaus B, Hackel M, Hofbauer H (2015) Polygeneration at the biomass steam gasification plant Oberwart - evaluation of process chains to produce hydrogen, electricity and heat. In: Proceedings of the 23rd European biomass conference and exhibition, Vienna, Austria. https://doi. org/10.5071/23rdEUBCE2015-2DV.1.12

103. Kraussler M, Binder M, Hofbauer H (2016) 2250-h long term operation of a water gas shift pilot plant processing tar-rich product gas from an industrial scale dual fluidized bed biomass steam 
gasification plant. Int J Hydrog Energy 41:6247-6258. https://doi. org/10.1016/j.ijhydene.2016.02.137

104. Loipersböck J, Lenzi M, Rauch R, Hofbauer H (2017) Hydrogen production from biomass: the behavior of impurities over a $\mathrm{CO}$ shift unit and a biodiesel scrubber used as a gas treatment stage. Korean J Chem Eng 34:2198-2203. https://doi.org/10.1007/ s11814-017-0130-1

105. Müller S, Groß P, Rauch R, Zweiler R, Aichernig C, Fuchs M, Hofbauer H (2017) Production of diesel from biomass and wind power - energy storage by the use of the Fischer-Tropsch process. Biomass Conv. Bioref. 7:1-8. https://doi.org/10.1007/s13399017-0287-1

106. Gruber H, Groß P, Rauch R, Weber G, Loipersböck J, et al (2017) Fischer-Tropsch synthesis - effects of feedstock load changes regarding product quality and catalyst attrition. In: Proceedings of the 25th European Biomass Conference and Exhibition, Stockholm, Sweden. https://doi.org/10.5071/25thEUBCE20173AO.9.4

107. Anghilante R, Müller C, Schmid M, Colomar D, Ortloff F, Spörl $\mathrm{R}$, Brisse A, GrafF (2019) Innovative power-to-gas plant concepts for upgrading of gasification bio-syngas through steam electrolysis and catalytic methanation. Energy Convers Manag 183:462-473. https://doi.org/10.1016/j.enconman.2018.12.101

108. Koppatz S, Pfeifer C, Hofbauer H (2011) Comparison of the performance behaviour of silica sand and olivine in a dual fluidised bed reactor system for steam gasification of biomass at pilot plant scale. Chem Eng J 175:468-483. https://doi.org/10.1016/j.cej. 2011.09.071

109. Koppatz S, Schmid JC, Pfeifer C, Hofbauer H (2012) The effect of bed particle inventories with different particle sizes in a dual fluidized bed pilot plant for biomass steam gasification. Ind Eng Chem Res 51:10492-10502. https://doi.org/10.1021/ie202353b

110. Poboss N (2016) Experimentelle Untersuchung der sorptionsunterstützten Reformierung. Doctoral thesis, University of Stuttgart, Germany

111. Hofbauer H, Materazzi M (2019) Waste gasification processes for SNG production. In: Substitute natural gas from waste, chapter 7. https://doi.org/10.1016/B978-0-12-815554-7.00007-6

Publisher's note Springer Nature remains neutral with regard to jurisdictional claims in published maps and institutional affiliations. 